\title{
Global trends towards urban street-network sprawl
}

\author{
March 2019 \\ DRAFT in revision/review: \\ please cite as OSF.io preprint \\ DOI:10.31219/osf.io/2cp5u
}

\section{Christopher Barrington-Leigh}

Institute for Health and Social Policy and McGill School of Environment

McGill University

1130 Pine Avenue West Montreal, QC H3A 1A3

Canada

+1 (438) 2384659

\section{Adam Millard-Ball}

Environmental Studies Department

University of California, Santa Cruz

1156 High Street, Santa Cruz, CA 95064

United States

+1 (831) 459-1838

Author Contributions: C.B.L. and A.M.B. designed research, performed research, analyzed data, and wrote the paper. Authors are listed alphabetically. The authors declare no conflict of interest.

CLASSIFICATION: SOCIAL SCIENCES / SUSTAINABILITY SCIENCES

ACKNOWLEDGEMENTS: We are grateful for excellent research assistance from Tássia Araújo, Gal Kramer, and Sabina Sloman, and to Elliott Campbell, John Armstrong, Nazanin Rezaei, Paulo Quadri, Rachel Voss, Ruihua Wang and Kai Zhu for helpful comments on earlier drafts. Our work was supported by Social Science and Humanities Research Council of Canada grant 435-2016-0531, the Hellman Fellows Program, and a UC Santa Cruz Faculty Research Grant. Most importantly, we thank the $\sim 5$ million contributors to the OpenStreetMap dataset. This article uses the LandScan 2012 global population data set from Oak Ridge National Laboratory. 


\section{Abstract}

We present the first global time series of street-network sprawl — that is, sprawl as measured through the local connectivity of the street network. Using high-resolution data from OpenStreetMap and a satellite-derived time series of urbanization, we compute and validate changes over time in multidimensional street connectivity measures based on graph-theoretic and geographic concepts. We report on global, national, and city-level trends since 1975 in the StreetNetwork Disconnectedness Index (SNDi), based on every mapped node and edge in the world. Streets in new developments in $90 \%$ of the 134 most populous countries have become less connected since 1975 , while just $29 \%$ show an improving trend since 2000 . The same period saw a near doubling in the relative frequency of a street-network type characterized by high circuity, typical of gated communities. We identify persistence in street-network sprawl, indicative of path-dependent processes. Specifically, cities and countries with low connectivity in recent years also had relatively low preexisting connectivity in our earliest time period. We discuss implications for policy intervention in road building in new and expanding cities as a top priority for sustainable urban development.

KEYWORDS: CLIMATE CHANGE POLICY, TRANSPORTATION, URBAN SPRAWL

\section{Significance}

The pattern of new urban and residential roads represents an essentially permanent backbone that shapes new urban form and land use in the world's cities. Thus, today's choices on the connectivity of streets may restrict future resilience and lock in pathways of energy use and $\mathrm{CO}_{2}$ emissions for a century or more. In contrast to the corrective trend observed in the USA, where streets have become more connected since the late 20th century, we find that most of the world is building ever-more disconnected "street-network sprawl." A rapid policy response, including regulation and pricing tools, is needed to avoid further costly lock-in during this current, final phase of the urbanization process. 


\section{Global trends towards urban street-network sprawl}

\section{Contents}

1 Introduction $\quad 4$

2 Recent development $\quad 5$

3 Trends in development $\quad 8$

4 Dynamics according to empirical street-network types $\quad 12$

5 Persistence $\quad 14$

$\begin{array}{llr}6 & \text { Policy and conclusion } & 17\end{array}$

\section{List of Figures}

1 Global map of recent street-network sprawl . . . . . . . . . . . . . 5

2 Trends for selected regions, countries, and cities . . . . . . . . . . . . 10

3 Map of nodal connectivity over time, Seoul . . . . . . . . . . . . . . . . . . 13

4 Street-network types and trends . . . . . . . . . . . . . . . 15

5 Trends in empirical types by world region . . . . . . . . . . . . . 16

6 Gated community examples . . . . . . . . . . . . . . . . . . . . . . . . . . . 17

7 Path dependence in street-network sprawl . . . . . . . . . . . . 18

\section{List of Tables}

1 Cities listed in order of recent urban street-network sprawl . . . . . . . . 6

2 Countries listed in order of recent urban street-network sprawl . . . . . . . . 7

3 Estimates of path dependence . . . . . . . . . . . . . . 15 


\section{Introduction}

As economic growth leads to an increasingly motorized world, energy use and greenhouse gas emissions from transportation are predicted to increase dramatically. The sector's energy use is expected to rise by $\sim 44 \%$ between 2015 and 2040 under current policies, with $\mathrm{CO}_{2}$ emissions from transport oil combustion rising by almost as much [1]. Global energy and integrated assessment models indicate that even under aggressive efficiency and electrification scenarios, transportation energy and emissions will see more limited reductions compared to other sectors $[2,1]$.

Most global analyses, however, model transportation energy demand as a function of income, energy prices, and technology, and take little to no account of how the physical structure of urban centers shapes household decisions on vehicle ownership and travel [3, 4], or of community decisions on transport infrastructure and services. While a large body of research shows that cities with high population density, connected street networks and fast and frequent public transportation systems tend to have less vehicle travel at a given income level $[5,6,7]$, such insights are hard to capture in global analyses. One reason is that there is limited data on urban spatial structure at the metropolitan level, and even less at the higher-resolution neighborhood level where household travel decisions are shaped. Thus, policy makers have little insight into underlying trends and the characteristics of new development, let alone about how these trends may affect future energy use and emissions.

In previous work [8], we began to fill this gap through creating a global data set of streetnetwork sprawl. Intuitively, connected street networks such as grids increase accessibility by walking, bicycling and public transportation, as more destinations can be reached in a given window of time. In contrast, disconnected networks that are dendritic or are dominated by culs-de-sac favor travel by the private car. In that paper, we created and reported (i) a summary measure, the Street-Network Disconnectness Index (SNDi); and (ii) a multidimensional classification of empirical types, based on analysis at the scale of individual nodes (intersections) and edges (street segments). We qualitatively validated their ability to capture and distinguish established urban planning-related characteristics of neighborhoods, globally, and showed that SNDi is associated with household car ownership and mode choice decisions in several high-income countries.

Our previous work focused on the stocks of streets, i.e. the characteristics of the entire network in a given place. In this paper, we focus on the dynamics of street-network sprawl and address the question of how patterns of street-network sprawl are changing among and within countries, worldwide. We couple our SNDi measure and empirical types with remote sensing data on urban growth to create a time series, and identify trends and the characteristics of new urban development from 1975-2014. We validate this approach using data on building construction dates (see Supporting Information (SI)).

Our paper is structured as follows. First, we discuss the connectivity of recent (post-2000) development at the national scale, as measured by low SNDi. Second, we characterize the ongoing trends in street-network sprawl in regions, countries, and cities, identifying a global decline 


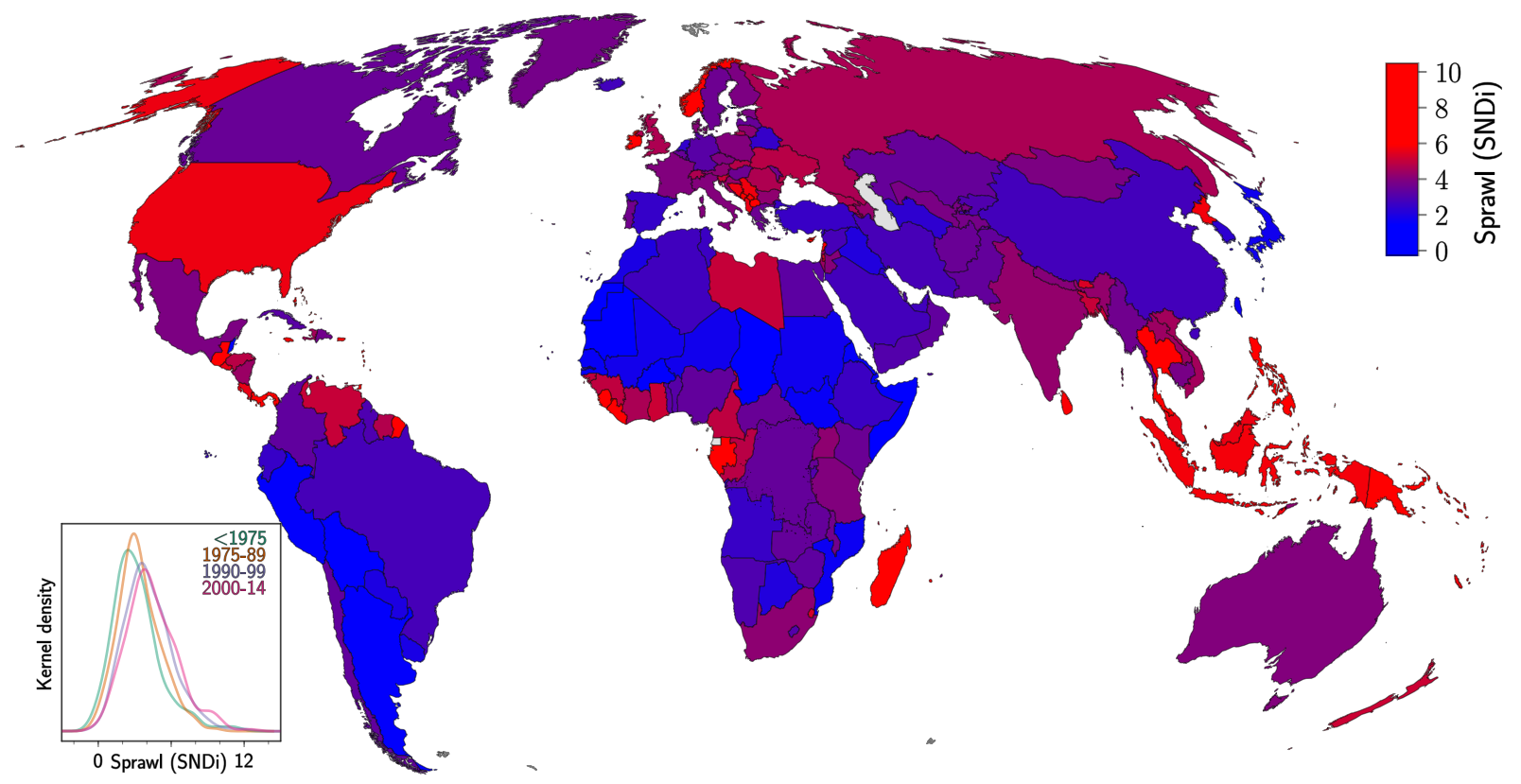

Figure 1: Street-network sprawl (SNDi) for streets added years 2000-14. The inset charts the distribution at the country level of SNDi for streets added in each of our four time periods.

in street connectivity since 1975, a peak in US street-network sprawl in 2000, and continued low levels of sprawl in places such as Japan. Third, we analyze trends in a multidimensional classification that identifies empirical street-network types, and document a rise in the prevalence of networks typical of gated communities at the expense of the irregular grid. Fourth, we explore persistence in street-network sprawl, i.e. the degree to which local- and country-level connectivity tends to reproduce itself over time, and discusses the potential role of path dependence. We conclude with implications for policy, including the potential of market-based and regulatory approaches.

\section{Recent development}

Environmental impacts are governed by the connectivity of the entire stock of streets, which is the product of decades or centuries of accumulated decisions by private developers and municipal governments. Policymakers, however, can normally only affect the increment of new streets that are added to the stock each year. Recently developed streets are therefore the best reflection of current urban planning policies and real-estate market forces, and we begin by discussing the considerable heterogeneity in our composite measure, SNDi, around the world in the most recent time period of our analysis, 2000-14 (Figure 1; Table 1; Table 2).

That the USA stands out for its disconnected streets comes as no surprise given the large literature on its automobile-oriented development patterns [e.g., 9]. Within the USA, the highest 


\begin{tabular}{|c|c|c|c|c|c|c|c|c|}
\hline & \multicolumn{4}{|c|}{ Sprawl (SNDi) } & \multicolumn{4}{|c|}{$\mathrm{N}$ (nodes) } \\
\hline & $<1990$ & $90-99$ & '00-13 & Stock & $<1990$ & $90-99$ & $00-13$ & Stock \\
\hline Bangkok, Thailand & 6.8 & 7.6 & 8.1 & 7.3 & $74 \mathrm{k}$ & $30 \mathrm{k}$ & $46 \mathrm{k}$ & $150 \mathrm{k}$ \\
\hline Guatemala City, Guatemala & 3.8 & 5.6 & 7.5 & 4.5 & $22 \mathrm{k}$ & $7.3 \mathrm{k}$ & $4.7 \mathrm{k}$ & $34 \mathrm{k}$ \\
\hline Cebu City, PhiLippines & 6.1 & 6.9 & 7.3 & 6.6 & $5.7 \mathrm{k}$ & $2.3 \mathrm{k}$ & $4.5 \mathrm{k}$ & $12 \mathrm{k}$ \\
\hline Los Angeles, United States & 3.6 & 6.2 & 6.3 & 3.9 & $250 \mathrm{k}$ & $26 \mathrm{k}$ & $9.7 \mathrm{k}$ & $290 \mathrm{k}$ \\
\hline Raleigh, United States & 4.8 & 5.4 & 6.3 & 5.6 & $11 \mathrm{k}$ & $21 \mathrm{k}$ & $19 \mathrm{k}$ & $51 \mathrm{k}$ \\
\hline Palembang, Indonesia & 4.7 & 5.6 & 6.3 & 5.2 & $15 \mathrm{k}$ & $19 \mathrm{k}$ & $3.9 \mathrm{k}$ & $39 \mathrm{k}$ \\
\hline New York, United States & 2.9 & 5.2 & 6.3 & 3.1 & $320 \mathrm{k}$ & $42 \mathrm{k}$ & $3.5 \mathrm{k}$ & $360 \mathrm{k}$ \\
\hline San Salvador, El Salvador & 4.4 & 7.1 & 6.1 & 5.0 & $11 \mathrm{k}$ & $1.7 \mathrm{k}$ & $4.7 \mathrm{k}$ & $17 \mathrm{k}$ \\
\hline Belgrade, Serbia & 2.9 & 6.6 & 6.0 & 4.2 & $9.1 \mathrm{k}$ & $2.2 \mathrm{k}$ & $4 \mathrm{k}$ & $15 \mathrm{k}$ \\
\hline Tijuana, Mexico & 4.3 & 3.6 & 6.0 & 4.4 & $15 \mathrm{k}$ & $9.2 \mathrm{k}$ & $8.5 \mathrm{k}$ & $33 \mathrm{k}$ \\
\hline$\vdots$ & 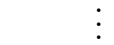 & : & & $\vdots$ & $\vdots$ & : & : & \\
\hline Gombe, Nigeria & 1.6 & 3.7 & 2.0 & 2.0 & $1.8 \mathrm{k}$ & 560 & $4.5 \mathrm{k}$ & $6.9 \mathrm{k}$ \\
\hline Busan, South Korea & 1.3 & 1.6 & 1.8 & 1.4 & $16 \mathrm{k}$ & $4.1 \mathrm{k}$ & $4.2 \mathrm{k}$ & $24 \mathrm{k}$ \\
\hline Tokyo, JAPAN & 1.1 & 1.6 & 1.8 & 1.1 & $660 \mathrm{k}$ & $38 \mathrm{k}$ & $97 \mathrm{k}$ & $800 \mathrm{k}$ \\
\hline Marrakesh, Morocco & 1.1 & 1.5 & 1.7 & 1.3 & $6.3 \mathrm{k}$ & $2.2 \mathrm{k}$ & $3.6 \mathrm{k}$ & $12 \mathrm{k}$ \\
\hline Madrid, Spain & 0.7 & 1.5 & 1.7 & 1.1 & $28 \mathrm{k}$ & $12 \mathrm{k}$ & $15 \mathrm{k}$ & $55 \mathrm{k}$ \\
\hline Buenos Aires, Argentina & -0.1 & 0.9 & 1.6 & 0.3 & $120 \mathrm{k}$ & $17 \mathrm{k}$ & $26 \mathrm{k}$ & $160 \mathrm{k}$ \\
\hline Bamako, MALI & 0.6 & 1.0 & 1.6 & 1.1 & $13 \mathrm{k}$ & $7.5 \mathrm{k}$ & $16 \mathrm{k}$ & $36 \mathrm{k}$ \\
\hline Luanda, Angola & 2.0 & 2.2 & 1.5 & 1.8 & $12 \mathrm{k}$ & $10 \mathrm{k}$ & $28 \mathrm{k}$ & $51 \mathrm{k}$ \\
\hline Lubumbashi, DR Congo & 1.7 & 1.8 & 1.3 & 1.5 & $6.7 \mathrm{k}$ & $2.3 \mathrm{k}$ & $7.7 \mathrm{k}$ & $17 \mathrm{k}$ \\
\hline Khartoum, SUdAN & 0.2 & 0.6 & 0.7 & 0.5 & $56 \mathrm{k}$ & $14 \mathrm{k}$ & $38 \mathrm{k}$ & $110 \mathrm{k}$ \\
\hline
\end{tabular}

Table 1: Cities listed in order of recent urban street-network sprawl. The top ten and bottom ten cities with $\geq 3,000$ street nodes, ordered by SNDi in recent development. A full list of 200 cities is in the SI. 


\begin{tabular}{l||rrrr|r|rrrr|r||}
\hline \multicolumn{1}{|c||}{} & \multicolumn{9}{|c|}{ Sprawl (SNDi) } & \multicolumn{4}{c|}{ N(nodes) } \\
& $<1975$ & $75-89$ & $90-99$ & $2000-13$ & Stock & $<1975$ & $75-89$ & $90-99$ & $2000-13$ & Stock \\
\hline \hline Puerto Rico & 4.9 & 7.7 & 8.9 & 9.4 & 6.5 & $54 \mathrm{k}$ & $47 \mathrm{k}$ & $12 \mathrm{k}$ & $8.2 \mathrm{k}$ & $120 \mathrm{k}$ \\
Ireland & 5.0 & 6.4 & 7.7 & 7.6 & 5.9 & $57 \mathrm{k}$ & $22 \mathrm{k}$ & $17 \mathrm{k}$ & $19 \mathrm{k}$ & $120 \mathrm{k}$ \\
Guatemala & 3.2 & 4.7 & 6.1 & 6.5 & 4.6 & $32 \mathrm{k}$ & $41 \mathrm{k}$ & $12 \mathrm{k}$ & $11 \mathrm{k}$ & $110 \mathrm{k}$ \\
Thailand & 4.0 & 4.7 & 4.8 & 6.3 & 4.9 & $140 \mathrm{k}$ & $470 \mathrm{k}$ & $74 \mathrm{k}$ & $120 \mathrm{k}$ & $920 \mathrm{k}$ \\
Philippines & 4.5 & 5.3 & 5.6 & 6.1 & 5.4 & $130 \mathrm{k}$ & $200 \mathrm{k}$ & $51 \mathrm{k}$ & $59 \mathrm{k}$ & $500 \mathrm{k}$ \\
Norway & 4.0 & 4.8 & 5.7 & 6.1 & 4.6 & $62 \mathrm{k}$ & $57 \mathrm{k}$ & $10 \mathrm{k}$ & $19 \mathrm{k}$ & $170 \mathrm{k}$ \\
Sri Lanka & 3.8 & 5.9 & 5.4 & 5.9 & 5.5 & $22 \mathrm{k}$ & $78 \mathrm{k}$ & $8 \mathrm{k}$ & $26 \mathrm{k}$ & $150 \mathrm{k}$ \\
Indonesia & 5.3 & 4.4 & 5.3 & 5.8 & 5.1 & $660 \mathrm{k}$ & $470 \mathrm{k}$ & $140 \mathrm{k}$ & $220 \mathrm{k}$ & $1.6 \mathrm{M}$ \\
Serbia & 3.0 & 4.3 & 5.3 & 5.8 & 3.8 & $56 \mathrm{k}$ & $32 \mathrm{k}$ & $4.1 \mathrm{k}$ & $4.7 \mathrm{k}$ & $100 \mathrm{k}$ \\
United States & 2.9 & 4.6 & 6.2 & 5.7 & 3.9 & $5.5 \mathrm{M}$ & $2.7 \mathrm{M}$ & $980 \mathrm{k}$ & $1.1 \mathrm{M}$ & $11 \mathrm{M}$ \\
$\vdots$ & $\vdots$ & $\vdots$ & $\vdots$ & $\vdots$ & $\vdots$ & $\vdots$ & $\vdots$ & $\vdots$ & $\vdots$ & $\vdots$ \\
Iraq & 2.1 & 1.8 & 2.0 & 2.2 & 2.0 & $28 \mathrm{k}$ & $150 \mathrm{k}$ & $21 \mathrm{k}$ & $110 \mathrm{k}$ & $320 \mathrm{k}$ \\
Morocco & 1.5 & 1.9 & 1.9 & 2.0 & 1.9 & $81 \mathrm{k}$ & $86 \mathrm{k}$ & $29 \mathrm{k}$ & $59 \mathrm{k}$ & $280 \mathrm{k}$ \\
Sudan & 0.6 & 1.1 & 1.6 & 1.8 & 1.6 & $64 \mathrm{k}$ & $52 \mathrm{k}$ & $12 \mathrm{k}$ & $92 \mathrm{k}$ & $320 \mathrm{k}$ \\
Japan & 1.1 & 1.5 & 2.2 & 1.8 & 1.3 & $2.8 \mathrm{M}$ & $990 \mathrm{k}$ & $130 \mathrm{k}$ & $110 \mathrm{k}$ & $4 \mathrm{M}$ \\
Taiwan, China & 1.1 & 2.1 & 2.0 & 1.8 & 1.3 & $130 \mathrm{k}$ & $12 \mathrm{k}$ & $7.9 \mathrm{k}$ & $7.5 \mathrm{k}$ & $160 \mathrm{k}$ \\
Mozambique & 2.1 & 1.2 & 1.7 & 1.7 & 1.8 & $16 \mathrm{k}$ & $33 \mathrm{k}$ & $16 \mathrm{k}$ & $38 \mathrm{k}$ & $130 \mathrm{k}$ \\
Senegal & 0.9 & 1.2 & 1.3 & 1.6 & 1.5 & $30 \mathrm{k}$ & $47 \mathrm{k}$ & $19 \mathrm{k}$ & $31 \mathrm{k}$ & $150 \mathrm{k}$ \\
Peru & 1.5 & 0.8 & 1.5 & 1.5 & 1.5 & $190 \mathrm{k}$ & $11 \mathrm{k}$ & $9.1 \mathrm{k}$ & $23 \mathrm{k}$ & $280 \mathrm{k}$ \\
Argentina & 0.2 & 0.5 & 1.1 & 1.5 & 0.6 & $300 \mathrm{k}$ & $310 \mathrm{k}$ & $84 \mathrm{k}$ & $69 \mathrm{k}$ & $820 \mathrm{k}$ \\
Bolivia & 1.3 & 1.1 & 1.0 & 1.2 & 1.5 & $42 \mathrm{k}$ & $34 \mathrm{k}$ & $26 \mathrm{k}$ & $36 \mathrm{k}$ & $170 \mathrm{k}$ \\
\hline
\end{tabular}

Table 2: Countries listed in order of recent urban street-network sprawl. The top ten and bottom ten countries and territories with $\geq 10 \mathrm{M}$ population and $\geq 100 \mathrm{k}$ street nodes, ordered by SNDi in recent development. Countries and territories with populations $>20 \mathrm{M}$ are listed in bold. A fuller list is in the SI. 
levels of sprawl are found in the states of Georgia, West Virginia, Maryland, Kentucky and Virginia. Georgia is dominated by metropolitan Atlanta, which regularly features at the top of city-level sprawl rankings [e.g., 10], while urban growth in Maryland and Virginia is largely accounted for by the suburbs of Washington, DC. Los Angeles, Raleigh and New York are three of the ten most sprawling global cities identified in Table 1; this reflects recent suburban and exurban development in places like New Jersey, rather than the urban cores. (Neither Atlanta nor Washington, DC are represented separately in our cities dataset.)

Figure 1 and the tables also reveal the sprawling streets of parts of Europe such as Ireland, Norway and the Balkan region; south-east Asia, particularly Thailand, the Philippines, Sri Lanka and Indonesia; and parts of Central America. All these countries have recently built streets with average SNDi $\geq 5.5$ (See Figure 1 for the global distribution). In Ireland, for example, the 2001-08 housing boom led to an upswing in suburban development characterized by car dependency and poor public transportation service, despite moderately high densities in the form of apartment buildings and duplexes [11, 12]. In south-east Asia, developer-driven urban growth caters to a new middle-class, with access centered around the private automobile, often in the form of gated communities [e.g. 13]; we discuss the experience of countries such as Indonesia and the Philippines in more detail in [8]. In central American countries such as Guatemala and El Salvador, meanwhile, the combination of weak planning institutions and high rates of crime have led to a boom in developer-led, middle-class housing on the urban fringe, again typified by gated communities [14]. For example, Guatemala City - the second most sprawling in Table 1 - was originally established under Spanish colonial rule on a geometric grid, but the contemporary city is characterized by informal settlements, many of which arose after earthquakes in 1917-18 and 1976; and by "fortified spaces" for the wealthy that are isolated from the rest of the city [15].

The most connected streets in the recent period are found in South America, where Bolivia, Argentina, Peru and Uruguay have SNDi $\leq 2.0$. Japan, much of north Africa and the Middle East, South Korea and China also lie in the lower-quartile of SNDi. Most of these places were characterized by low levels of sprawl in previous time periods as well; the extent of this persistence over time is discussed further in Section 5.

\section{Trends in development}

An examination of trends in street-network sprawl since 1975 provides a complementary picture to the cross-sectional analysis of recent urban development, and helps indicate the direction of market preferences and planning policies. The trends for geographic regions and income groupings are shown in Figure $2 \mathrm{~A}$ and $\mathrm{B}$, while numerous details are evident at increasing

levels of disaggregation (panels $\mathrm{C}$ and $\mathrm{D}$ ). Plots and tabulated rankings for all countries are provided in the SI.

The last four decades have seen a striking global trend towards increased street-network sprawl, as reflected in the rightward shift of the distributions of SNDi (Figure 1 inset). More- 
over, new development in almost all geographic regions shows a marked rise in SNDi, at least until the turn of the century (Figure 2A). Sprawl in Latin America, Asia, and the EU rises monotonically and, except in the EU, nearly uniformly throughout our time series. Globally (Figure 2B, broad dark line), street-network sprawl rose during the first two time periods and flattened out in the most recent one, at a level comparable to that being built in the 1980s in the United States. This corresponds to a $27 \%$ decrease (from $32.5 \%$ to $23.9 \%$ ) in the fraction of urban intersections with degree-4+, and a 35\% increase (from 14.4\% to 19.4\%) in the fraction of dead-ends (see SI). While Figure 2 shows that the node- and edge-weighted global trend in SNDi has nearly plateaued, its future trajectory will depend on the relative rate of road expansion in areas practicing high- versus low-connectivity street construction. In the SI we show cities and countries according to the estimated rate at which their street network is growing.

In 1975, the global stock of streets showed relatively little variation among income groups. Since then, however, the distribution has considerably diverged according to income levels, with higher-income countries building less-connected developments. Due to the strong reversal exhibited by North America, the recent decrease of already-low-SNDi in Japan, and the leveling-off in the EU, overall the "high income" countries have recently arrested the radicallyincreasing trend of low-connectivity street construction. Despite the turnaround, recent construction in these countries remains less connected than other country groups (Figure 2B).

In fact, the leveling-off in high-income countries and on Earth as a whole reflects in large part the recent decline of SNDi in North America, which accounts for 20\% and 19\% of mapped nodes and edges, respectively, and thus counterbalances trends elsewhere in the world. In the United States, as previously reported [10], street-network sprawl exhibited an extraordinarily steep rise until the mid-1990s, but thereafter has been in decline. Interestingly, neighboring Canada followed a similar trend to the USA, with a steep increase in SNDi followed by a turnaround in the 1990s, but it peaked at a much lower level (SNDi =3.7; see SI), reflecting higher fuel prices and a more limited highway construction program in Canada, as well as differences in local land-use regulations [19, 20].

Other high-income countries and geographic regions have followed a different path from that of North America. Indeed, the high-income grouping also includes one of the least sprawling countries (Japan), with the European Union lying almost precisely midway between the USA and Japan. Nearly all European countries show increasing SNDi until the turn of the century, including the outlier Ireland (discussed in Section 2), which started and remained less connected than any other European country, but followed a parallel trajectory to Europe as a whole. This is consistent with the trend towards more car-oriented transportation and development in Europe over those decades [21]. However, the declining connectivity of new streets in many European countries has been arrested since 2000, and the UK even shows a significant shift away from sprawl (decrease in SNDi) in this time period.

For several European countries, notably Denmark and the UK, our estimates of street connectivity are strongly affected by pedestrian and bicycle paths (see Methods and SI for details of how we include them in calculating connectivity). In Denmark, where streets are becoming steadily less connected in the most recent period, bicycle and pedestrian paths appear frequently 


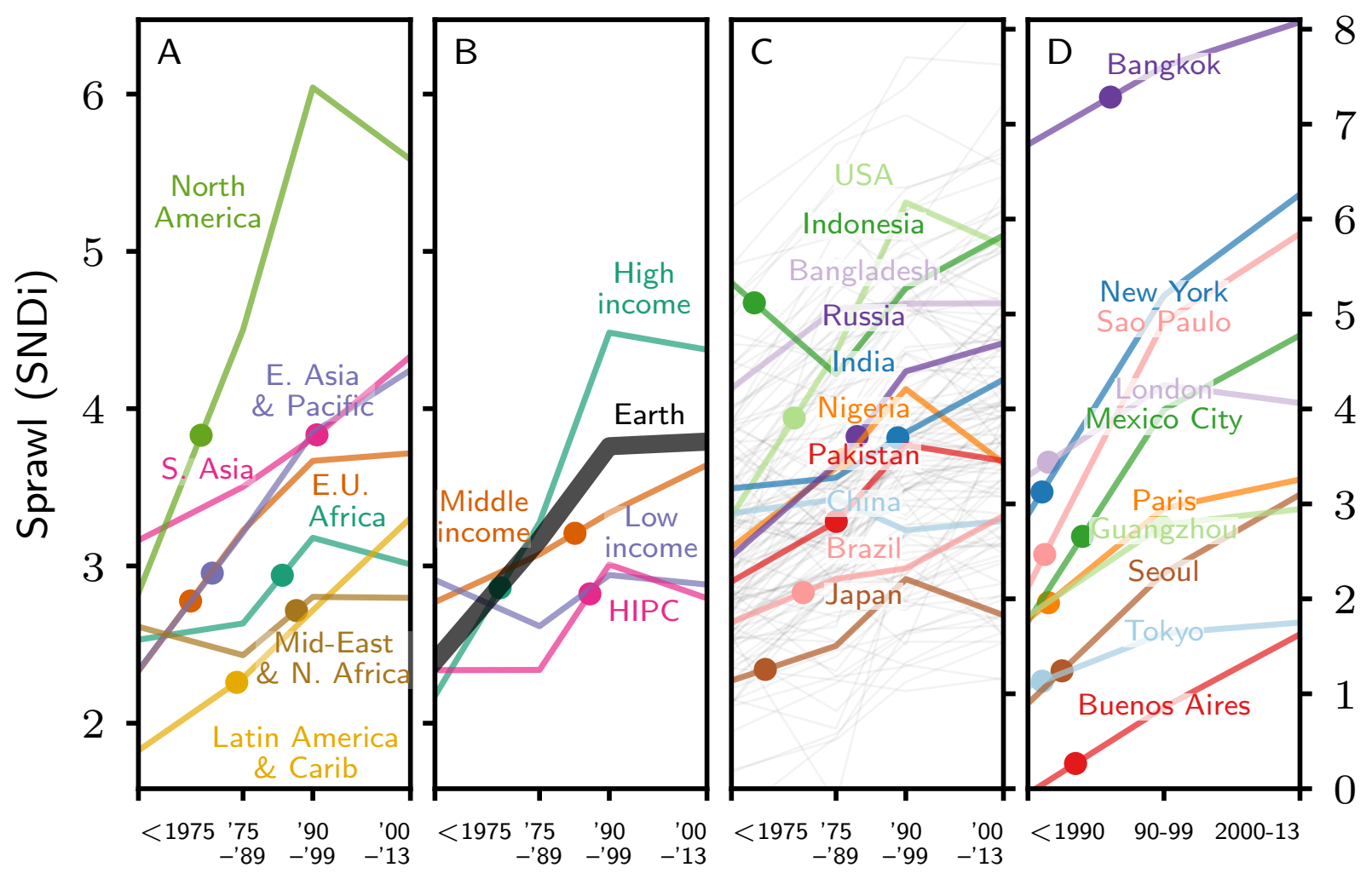

Figure 2: Regional trends in street-network sprawl SNDi. The first three panels show levels of our composite sprawl measure for the stock of streets built prior to 1975 in urban areas, followed by the SNDi of new urban construction during each successive period, 1975-1989, 1990-1999, and 2000-2013 [16]. The vertical positions of dots denote the SNDi of the 2017 stock of streets. A: Urban region averages of SNDi for several geographic regions. B: The global urban region aggregate is shown with a broad dark line, along with trends for five World Bank-defined economic and cultural country groups [17], including the heavily indebted poor countries (HIPC). C: Trends for the ten largest countries by population in color, and for the next 90 largest countries in thin grey lines. D: Trends for ten large cities, based on time series of their urban development boundaries [18]. Note that cities are aggregated to a separate set of time periods (prior to 1990, 1990-1999, and 2000-2013); see Materials and Methods for details. 
to be integrated into new developments, and significantly increase connectivity even if limited circulation is provided for cars. For example, adjacent culs-de-sac in new developments are normally connected by a foot- and cycle-way.

By contrast, Japanese street-network sprawl has remained low and recently turned around to an improving trend. We note the correspondingly low per capita $\mathrm{CO}_{2}$ emissions in Japan [22]. Other exceptions to the dominant pattern of increasing sprawl throughout the last quarter of the 20th century are found in Africa and the Middle East, where SNDi has risen little since 1975. Correspondingly, low-income and highly-indebted poor countries have collectively shown nearly constant connectivity over time, with new developments exhibiting similar SNDi to the pre-1975 stock in North America.

Latin America was, like Japan, already considerably urbanized at the beginning of our time series, and had similar SNDi in 1975. In Latin America, this can be partly ascribed to the Spanish colonial legacy of grid-like street patterns [23]. Bolivia, Belize, Argentina, Peru, and Uruguay lie near the bottom (most connected) of a country-level ranking of SNDi in 2000-2013, with SNDi $<2.0$ and average nodal degree of $\sim 3.2$. Yet, streets from earlier time periods in these countries were even better connected - particularly in Argentina and Uruguay, which in 1975 had SNDi $<0.2$ and nodal degree $\sim 3.5$. The Latin American trend towards streetnetwork sprawl (higher SNDi) in recent developments is among the strongest in the world, and has increased monotonically on every dimension included in SNDi.

Among more recently and rapidly urbanizing large countries, Indonesia both started (stock in 1975) and ended (development in the 2000-13 period) with the most sprawling street networks of any of the most populous countries. Another remarkable feature is the divergence of India, with increasing SNDi, and China, with the opposite trend, even though the stocks in 1975 were characterized by similar levels of connectivity. This divergence reflects in particular our graph-theoretic measures of nodal degree and the fraction of edges in the cycle basis (see SI), which remained stable in China but trended monotonically towards sprawl in India. When measuring sprawl through the geographic measures of circuity, both countries are becoming more sprawling, but India at a faster rate. Thus, all our measures suggest the same divergence of street-network development styles between Earth's two most populous countries. While the underlying street-network data are less complete in China [24], this finding is consistent with other evidence on Chinese urban development patterns. Indeed, many of China's new residential developments are characterized by "super-blocks" or sparse grids, which are connected but less conducive to walking than a finer-grain network $[25,26]$.

City trends (Figure 2D, tabulated more completely in the SI) reflect the regional and nationallevel patterns, with extremely high and growing SNDi in southeast Asian cities, notably Bangkok; stable or slowly increasing SNDi in European cities along with Tokyo and Guangzhou; and rapidly-increasing SNDi in initially-well-connected Sao Paulo, Mexico City and Buenos Aires. The cities of Manchester and Sheffield, like London, have recently turned towards decreasing SNDi, as has, even more dramatically, the United Kingdom, following a long period of broader trends towards increased sprawl [27]. Seoul, and indeed South Korea as a whole, represents another example of initially high but rapidly worsening connectivity, as depicted in Figure 3, 
which also shows the within-city variation at the level of individual edges and nodes. New York and Los Angeles, where recent development is less connected than in any other equally large global city in our analysis, are examples of regions with highly gridded urban cores whose suburban development in recent decades has been at the opposite extreme. Stocks and trends are tabulated and plotted for 200 cities and all countries in the SI.

Recent development in some cities makes them stand out nationally. For instance, in São Paolo and, even more so, Florioanópolis, recent development is characterized by extremely low connectivity (SNDi $>5.8$, mean degree=2.6) as compared with the recent country mean in Brazil (SNDi $=2.9$, mean degree=3.0). Interestingly, SNDi in São Paolo has evolved nearly identically to that in New York. While the older core of São Paolo is complex, it consists largely of gridded streets like those of New York, while the outer developments are increasingly circuitous. Tijuana, Mexico is another city with unusually disconnected development since 2000 (SNDi =6.0), as compared with the rest of Mexico (SNDi =3.9), although it is similar to the average for close-by United States (SNDi $=5.7$ ). While Thailand as a whole is building low-connectivity streets (recent SNDi $\approx 6.3$ ), Bangkok (recent SNDi =8.1) stands out within Thailand as well as globally. Fewer cities are national outliers in the other direction, i.e. with lower SNDi than the national average.

\section{Dynamics according to empirical street-network types}

Our composite measure (SNDi) analyzed in the preceding sections gauges the overall connectivity of the street network. In this section, we complement that composite measure with a categorical analysis, which classifies every urban grid cell into one of eight street-network types. Such a multidimensional classification enables distinctions to be drawn between places with similar overall connectivity as measured by SNDi, but where that level of connectivity is achieved through different designs. Figure 4 shows the eight types as identified in [8]. Types $\mathrm{B}$ and $\mathrm{C}$, for example, have similar levels of SNDi, but Type B achieves this through degree-3 intersections, while Type $\mathrm{C}$ has more degree-four intersections arranged in an irregular grid. Types E and F also have similar SNDi values, as do Types G and H.

The line plots in Figure 4 show the trends in the distribution of types over time, while Figure 5 shows the trends by world region. Overall, the message from the two figures reinforces the results presented above. That is, the proportion of nodes in the most disconnected types $(\mathrm{E}, \mathrm{F}$, $\mathrm{G}$ and $\mathrm{H}$ ) nearly doubled between pre-1975 development and the most recent period (2000-14), with the increase particularly pronounced in Europe, Asia and Latin America. There was also a sharp increase in the prevalence of disconnected types in North America, reaching a peak of $67 \%$ of nodes in Types E, F, G and H in 1990-99. Recent additions to the street network in North America, however, show a modest shift back towards more connected types, in accordance with the fall in SNDi since 1999.

Of these disconnected types, Type E (circuitous) has shown the largest increase over the period studied, rising from $9 \%$ of nodes pre-1975 to $17 \%$ in the $2000-14$ period. The proportion 


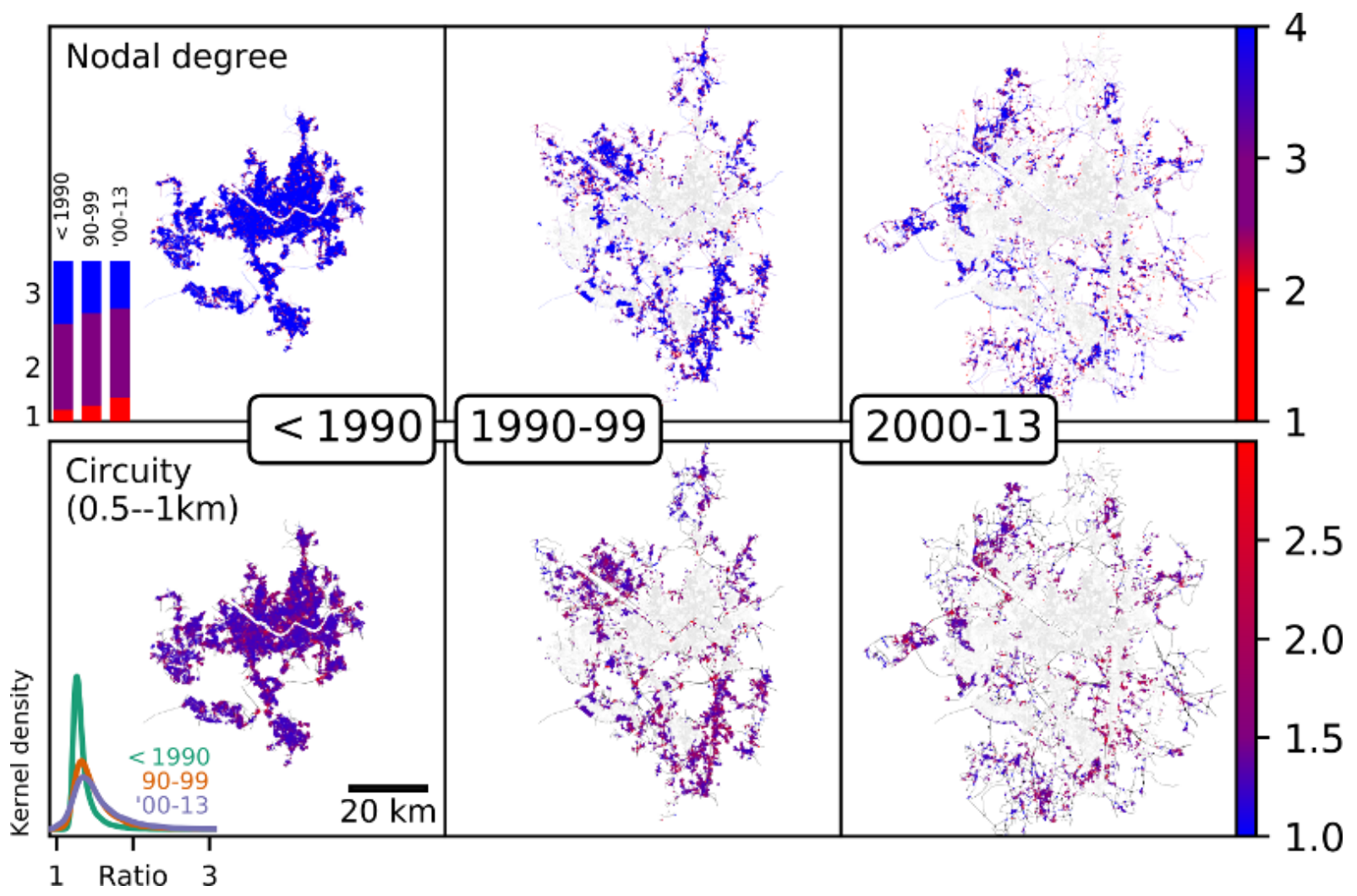

Figure 3: Map of nodal connectivity over time, Seoul. Blue streets are the most connected. Inset plots show the distribution of nodal degree (top) and circuity (bottom) for the three time periods. Streets built since 1990 on the urban periphery, particularly to the southeast and northwest, have become steadily more sprawling according to both of the connectivity measures illustrated here. A high-resolution version of this figure is linked in the SI. 
of nodes in Type E has increased in every region except Africa, and more than doubled in most regions. Type E often represents gated communities, as well as places with topographic barriers; some examples are shown in Figure 6. Demand for gated communities are is often driven by a fear of crime or a search for social prestige, but many analysts have raised concerns about their consequences for social segregation and for allowing a high-income elite to opt out of municipal service provision [28], as well as for their car dependence.

At the other end of the sprawl spectrum, grids (Type A) are the most self-evidently connected type. In the pre-1975 period, North America and Latin America were home to the highest proportions of Type A (grid), at $9 \%$ and $13 \%$ respectively. Since then, grids have declined in importance in Latin America and almost disappeared entirely in recent North American development, with that decline only partially offset by a marked upswing in the East Asia \& Pacific region (Figure 5). However, the global reduction in street connectivity has little to do with the abandonment of grids, which even in 1975 accounted for just $6 \%$ of nodes worldwide, declining to $3 \%$ in the $2000-14$ period. Instead, the largest decrease, from $43 \%$ to $28 \%$ of nodes at the global level, has occurred in Type C (irregular grid). The small rise in Type B (degree-3), which has similar SNDi to Type C, has only partially compensated for the decline in irregular grids.

\section{Persistence}

We previously found that early street-network sprawl predicts the connectivity of later construction at various geographic scales within the United States [10]. In addition to a persistence of local geographic variation in prices, policy, preferences, and other drivers of development style, there are plausible path-dependent processes in which urban form tends to replicate itself in new, neighboring developments [10, 29, 8]. For instance, the connectivity of existing street networks is likely to influence neighboring development due to the availability, or expectation of future availability, of services and transit options accessible to pedestrians. Building a walkable neighborhood is more valuable if there are places to walk to.

Our findings show that the same persistence is observed at the scale of entire countries (Table 2) as well as cities (Table 1). Places ranking high in recent SNDi also had relatively high SNDi in our earliest time period. To quantify this persistence as well as the average shift over time, we estimate the relationship between SNDi stock at our earliest time points (1975 for countries, 1990 for cities) and the SNDi characterizing the most recent construction (Table 3). Both the average shift and the persistence are consistent across geographic scales and different measures comprising SNDi: they indicate an overall shift towards lower connectivity, and a strong relationship between preexisting connectivity and recent connectivity. In fact, hardly

any countries or cities are building better-connected streets than they were in our earliest time periods (i.e., lie below the dark grey line in Figure 7), with China being a prominent exception. Other exceptions are mostly countries in the Middle East and Africa. 


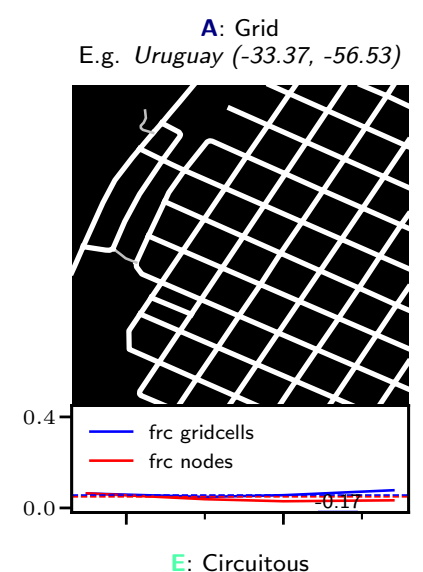

E.g. Philippines (14.43, 121.00)

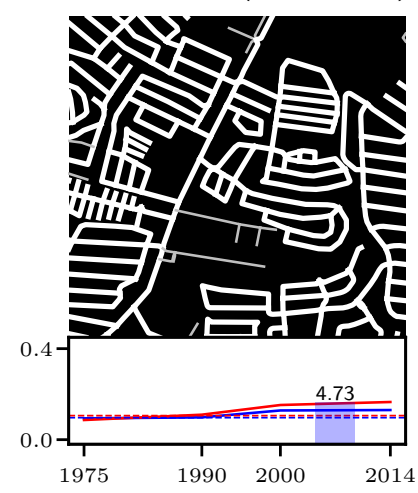

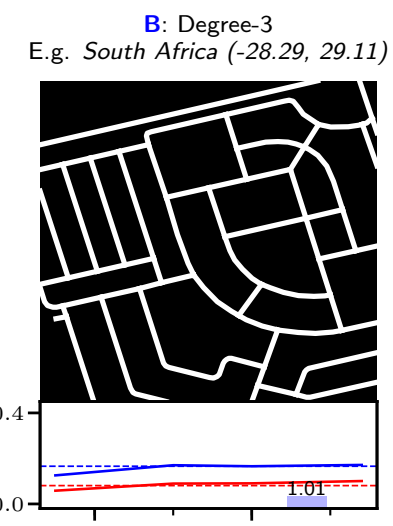

: Dead ends

E.g. Palestine $(31.39,35.08)$

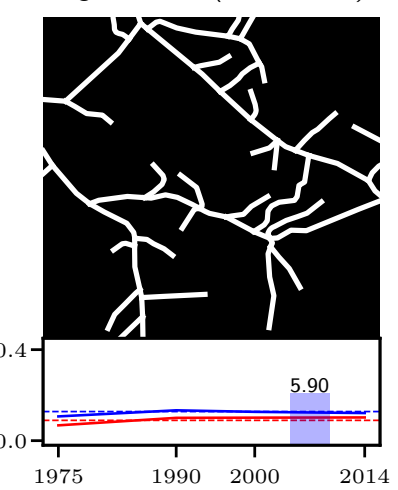

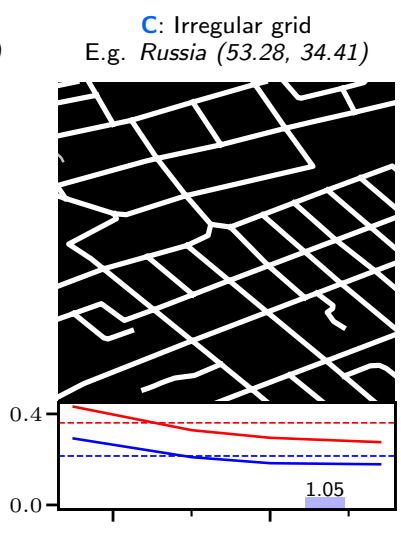

G: Dendritic

E.g. South Korea $(37.38,127.20)$

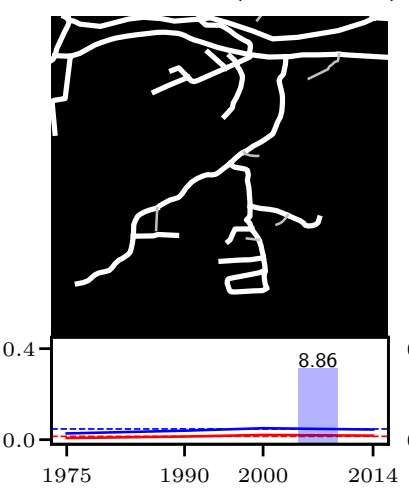

D: Broken grid

E.g. India (13.07, 80.21)

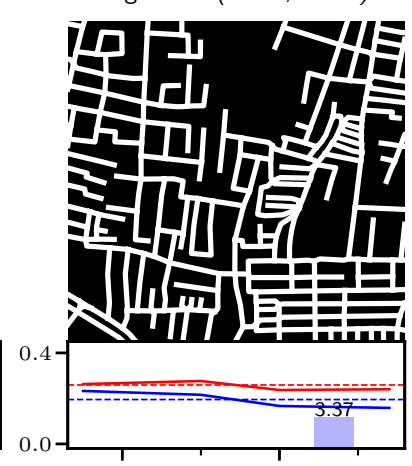

$\mathrm{H}$ : Disconnected

E.g. United Kingdom (54.57, -6.02)

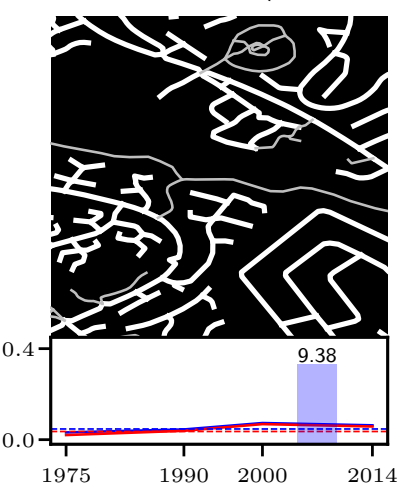

Figure 4: Empirical street-network types. For each type, streets in a grid cell near the cluster's centroid are shown [8], along with a line plot of the proportion of grid cells (blue) and proportion of nodes (red) that fall into each type over time. Types are shown in order of decreasing SNDi, indicated by the blue bar and associated number. The caption indicates the (latitude, longitude) of each example grid cell as well as the country where it is located.

\begin{tabular}{rrrr}
\hline Metric & Scale & Shift & Persistence \\
\hline \hline Log circuity (0.5-1km) & Cities & $.037 \pm .002$ & $.80 \pm .14$ \\
& Countries & $.029 \pm .002$ & $.91 \pm .12$ \\
Nodal degree & Cities & $-.22 \pm .013$ & $.68 \pm .12$ \\
& Countries & $-.17 \pm .012$ & $.82 \pm .10$ \\
SNDi & Cities & $1.56 \pm .081$ & $.85 \pm .13$ \\
& Countries & $1.26 \pm .081$ & $.89 \pm .10$ \\
\hline
\end{tabular}

Table 3: Estimates of path dependence. Mean shift ( \pm standard error) in connectivity measures between 1975 (countries) or 1990 (cities) and more post-2000 construction, and slope ( \pm standard error) of corresponding regression lines. Data and fits are displayed in Figure 7. 

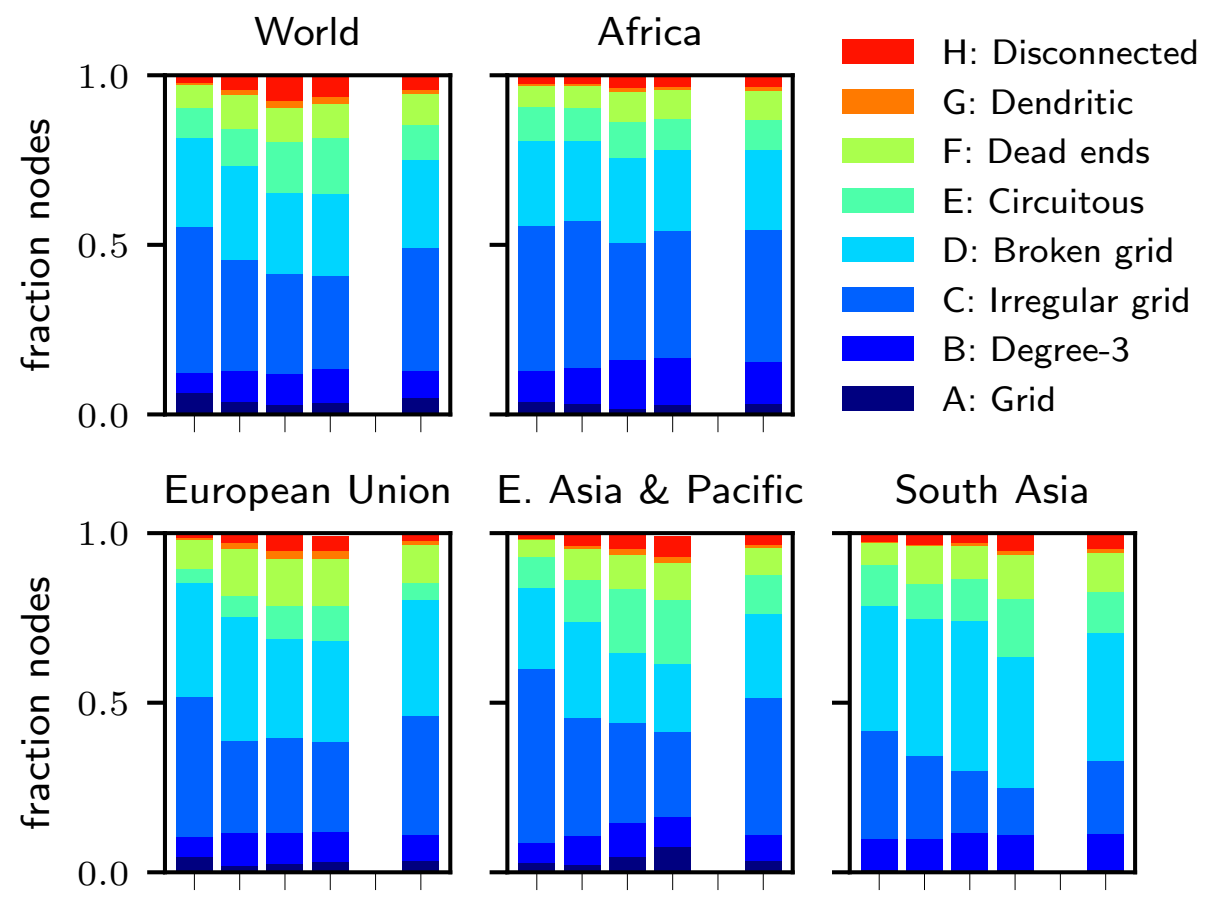

E. Asia \& Pacific
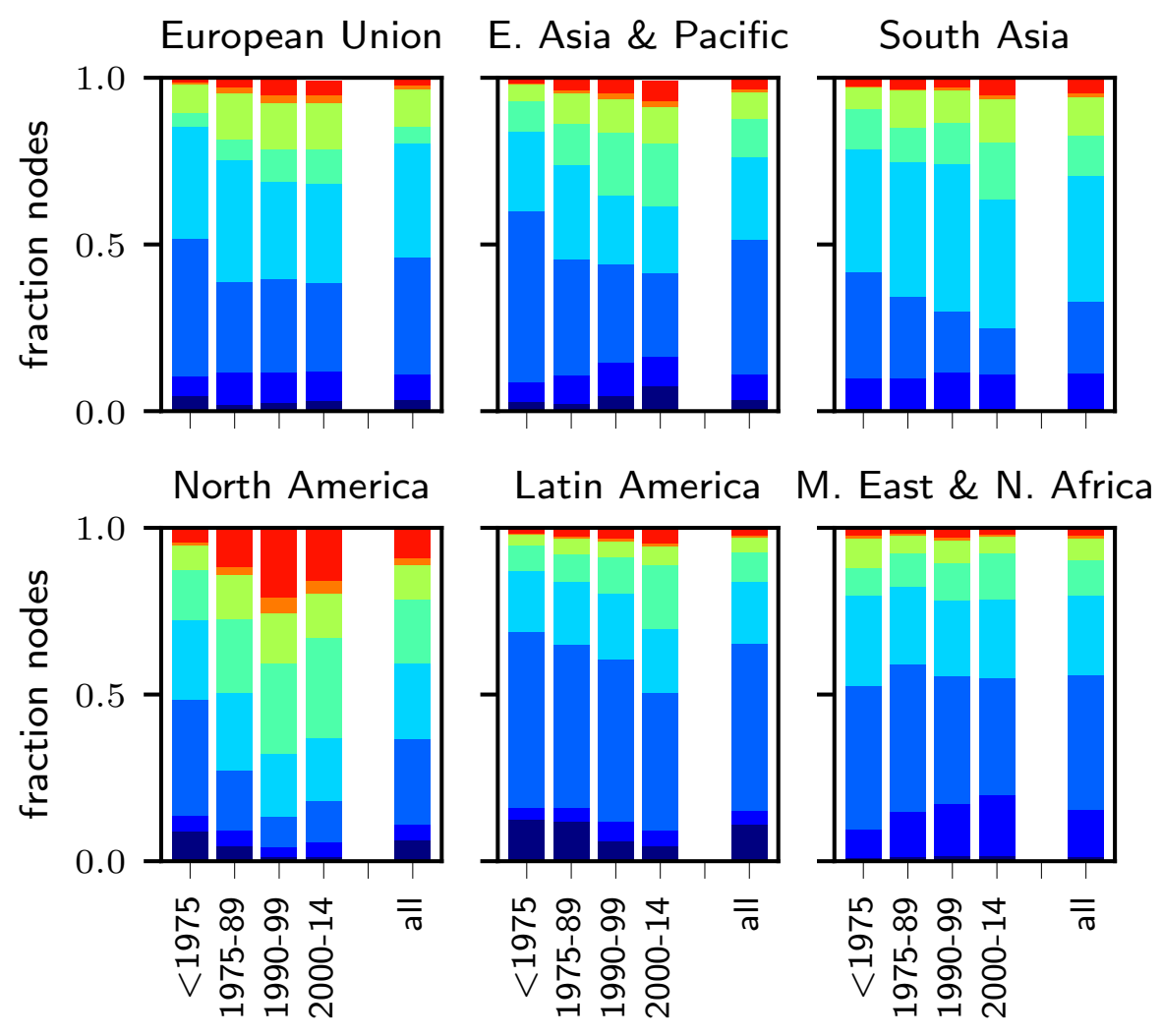

Figure 5: Trends in empirical types by world region. The fraction of nodes that fall into each of the empirical types is given for selected World Bank-defined regions. Plots for additional regions, for both the fraction of nodes and the fraction of grid cells that fall into each type, are shown in the SI. 


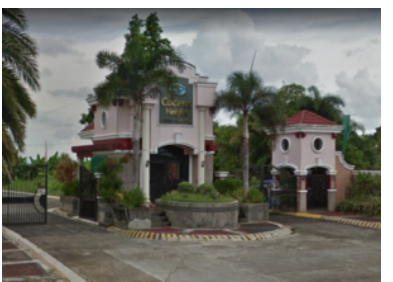

$13.65^{\circ} \times 123.2^{\circ}$

Phiippines

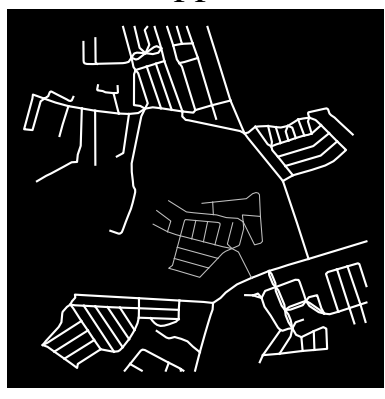

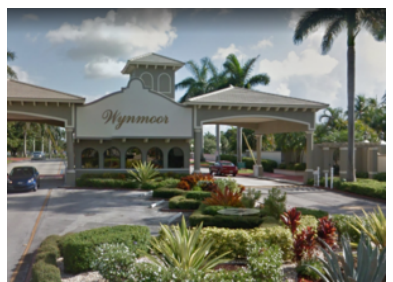

$26.25^{\circ} \times-80.17^{\circ}$

USA

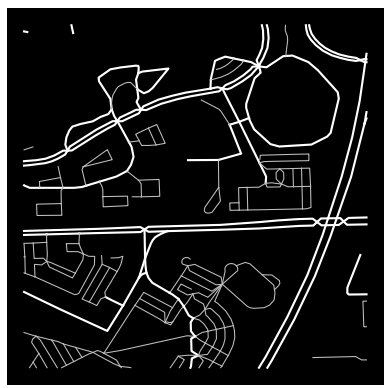

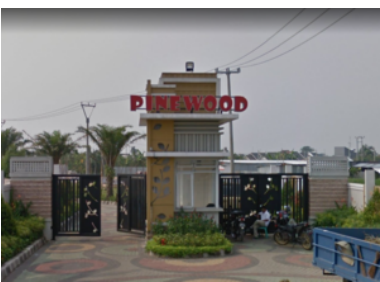

$-6.54^{\circ} \times 106.79^{\circ}$

Indonesia

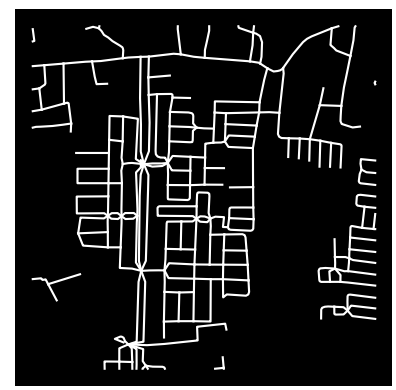

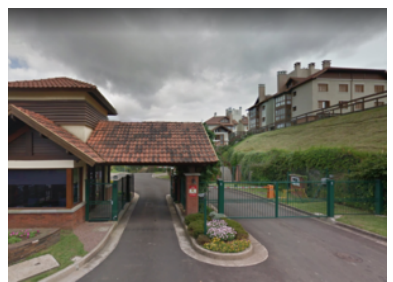

$-29.38^{\circ} \times-50.89^{\circ}$

Brazil

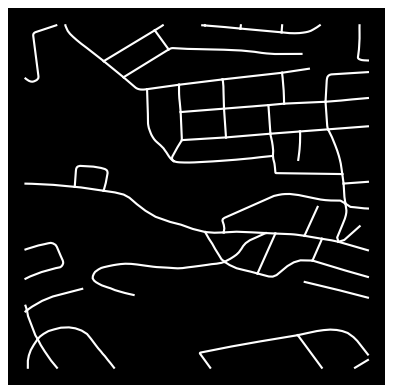

Figure 6: Gated community examples. These examples are from grid cells close to the centroid of Type E.

\section{Policy and conclusion}

In this paper, we use a globally consistent composite measure, SNDi, to quantify trends in streetnetwork sprawl in countries and large cities worldwide. While sprawl has increased in many of the "usual suspects" such as São Paulo, Los Angeles and Lagos, our findings show that some of the least connected street networks are found in places that have received less attention in the literature. The growth of large cities in China has been the subject of considerable media and academic interest, but these urban centers have moderate and relatively stable levels of street connectivity. In contrast, the most sprawling cities on the planet - and those that are trending towards even greater extremes - are found in southeast Asia, and have attracted more limited attention.

We also identify the diversity of ways in which street networks can grow in a connected or less connected pattern. Gridded street networks are a primary means through which Latin American countries such as Bolivia, Argentina, and Peru have maintained their high levels of connectivity - and the move away from the grid characterizes sprawl in large Brazilian cities such as São Paulo. However, Japan has maintained low levels of sprawl via a more organic, irregular grid pattern. Northern European countries such as Germany, Denmark and the UK, meanwhile, have maintained moderate levels of street connectivity through dedicated pedestrian and bicycle pathways, meaning that the network for non-motorized travel is far more connected than that for cars and trucks.

Our work has some natural limitations. First, our rationale for prioritizing a street-network measure of sprawl is in part based on causal pathways which still require further empirical 


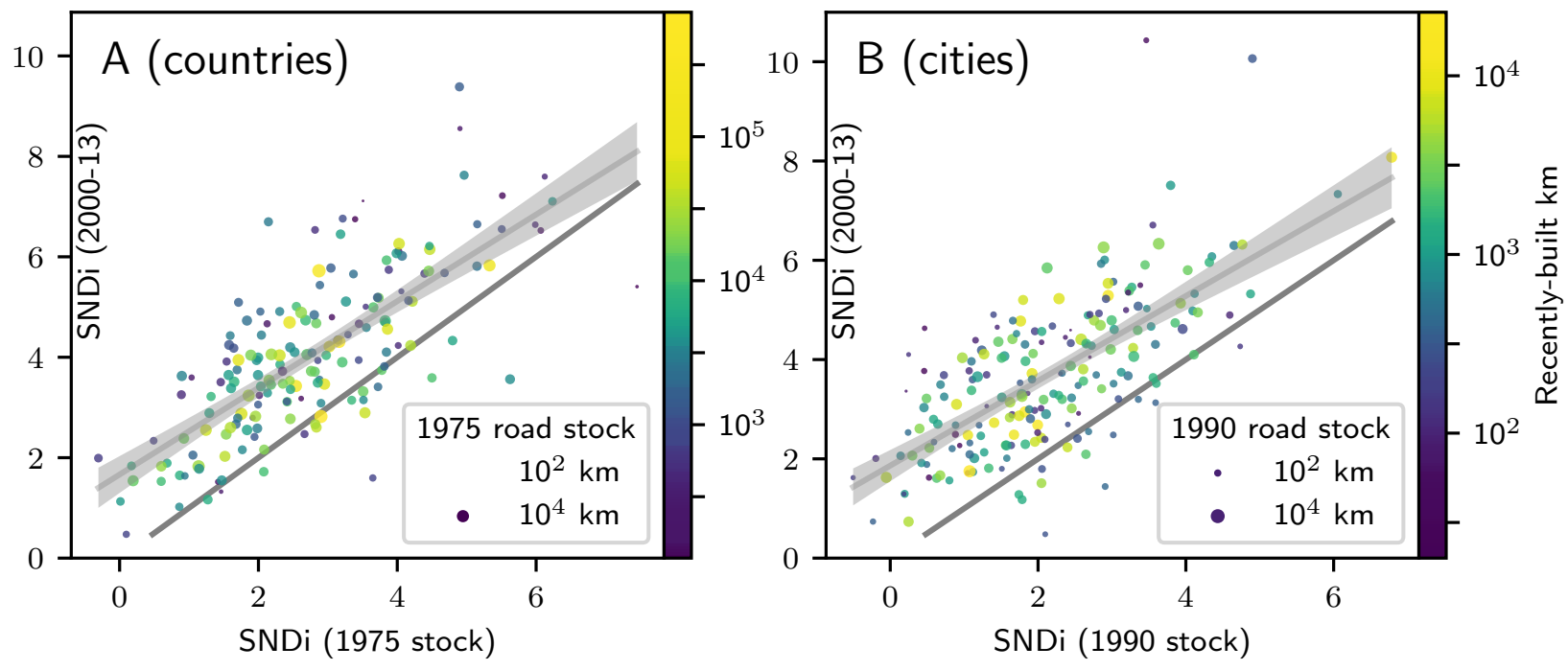

Figure 7: Path dependence in street-network sprawl. SNDi of recent (2000-2013) construction is closely correlated with that of the earlier road stock in 1975 (countries, A) and 1990 (cities, B). Circle size denotes the length of original road stock, while color indicates the scale of recent construction. Only cities and countries with at least $100 \mathrm{~km}$ of new roads are shown. Linear fits characterizing the persistence relationship (gray shaded confidence region) are nearly parallel to the 45 degree line of perfect persistence (dark grey line) indicating a relatively uniform shift (on average $\Delta \mathrm{SNDi}=+1.56$ for cities, +1.26 for countries; see Table 3 ) away from earlier high connectivity. A zoomable version of this figure with labels for cities and countries is in the SI. 
investigation. While SNDi and its constituent components, along with related measures of urban form such as density and housing type, are strong predictors of current car ownership and travel behavior [29, 8, 30, 31, 32], the relationship between initial street-network connectivity and the subsequent long-run evolution of density remains a ripe subject for future work. Our global SNDi time series should facilitate such research.

Second, an important premise of our current analysis is a sufficient completeness of the underlying street-network database, which we take from OpenStreetMap (OSM). We have demonstrated elsewhere that OSM is relatively complete [24], but those estimates excluded pedestrian and bicycle paths and service roads, which we incorporate in our measure of SNDi because they are demonstrably important to connectivity in some places. This leaves our work dependent also on the sufficient completeness of OSM's pedestrian and bicycle path records. Nevertheless, our inspections suggest that where such paths are numerous, they are well mapped in OSM. Where they are prominent, but possibly incompletely recorded in OSM, we may be underestimating connectivity.

\section{Worsening sprawl and its consequences}

Overall, our analysis shows that in large parts of the world, recent urban growth has increasingly resulted in inflexible and disconnected street networks. Countries with road networks that are among both the fastest-growing and the most disconnected include Thailand, the Philippines, Indonesia, and the United States, while cities of the same description include Bangkok, Johannesburg, Raleigh, Los Angeles, New York, Ho Chi Minh City, and São Paulo. However, our data reveal variation in development style within countries as well as within cities.

Our network-centered approach to quantifying sprawl therefore breaks from the dominant extant emphasis on low density and land use dispersal [33]. Urban outcomes in the short term have to do with much more than the street network. However, in the long run, sidewalk and transit provision, densities, land uses and both formal and informal rule enforcement are malleable to social, economic, and policy influences. By contrast, streets are a more permanent feature of cities; once laid down, their routes almost never change, even in the face of natural disasters such as earthquakes or fires [34]. Given that many cities will continue to grow for decades, density may change and outlying regions may be subsumed into more continuous development, but disconnected street routes will remain as a fundamental constraint. Thus we have previously conjectured that in the long term, low-connectivity street networks lack resilience to adapt to changing pressures and resources and ultimately densify towards mixed-use, transit-integrated, energy-efficient urban form. In this sense, they are effectively "density-proof," i.e., resistant to changing the mix of uses, modes of transportation, and density [29] In addition, in a practical policy context, the regulation of development style and infrastructure is somewhat separable from decisions about the conversion of agricultural and natural lands into urban use. Based largely on this logic, we expect our street-network measure to be a key predictor of future climate, energy, health, and social outcomes related to urban form.

The impact of today's street connectivity decisions on climate and other outcomes is ampli- 
fied by the tendency of new development to mimic existing urban form (Table 3). One mechanism we have proposed for this [10,29] is a spatial spillover from existing settlement structure onto the choices of future, neighbouring land developers. A neighbourhood with highly permeable streets is more likely to allow transit to access an adjacent future development, more likely to contain local services and jobs accessible to pedestrians living nearby, and so on. Building high-connectivity, pedestrian-navigable streets in the adjacent development therefore has economic complementarities with the connectivity of the existing street network. In other words, one interpretation of our findings of persistence is a long-run path-dependence in urban evolution, rendering any initial design decision all the more pivotal for future human and environmental outcomes.

In our categorical analysis of street-network types, gated communities arose as a particularly illustrative instance of low-connectivity planning. While gated communities have been documented across every continent, including in Istanbul, Indonesia, the United Kingdom and the United States, and single-country or qualitative studies have suggested their increasing prevalence $[35,28,13]$, ours is the first global analysis that documents the extent of their reach. In addition to their association with low walkability, car orientation, and land-use segregation, gated communities have obvious significance for other global challenges related to economic disparities and social segregation.

\section{The need for policy attention}

What, then, do these widespread trends imply for policy, especially given the rapid pace of urban road construction in many parts of the world - a process that is likely to be largely completed this century? The costs of high street-network sprawl are largely externalized to neighboring developments and to future generations, so regulatory intervention is a natural approach. Several feasible policies might be sufficient to increase connectivity in new developments. The simplest would be to require that, where possible, new communities are completely gridded, given that grids do well according to all of our street-network sprawl metrics. An alternative requirement would be a "three-ways-out" rule, which requires that three non-touching routes exist from every new intersection to points outside a new development. Gated communities could be discouraged or outright prohibited.

Market approaches can be used in place of regulatory policies, or in combination with them. For example, a tax on dead-ends and 3-way intersections, which we call a "cul-de-tax", could internalize some of the external costs of street-network sprawl. Moreover, broader environmental tax policies - such as carbon taxes, motor fuel taxes or congestion pricing - have led to increased residential densities and decreased construction on the urban periphery [6]; they might reasonably be expected to encourage developers to build more connected street networks as well.

Design guidance can also play a role. For example, the turnaround in the United Kingdom as a whole and in several British cities occurred in 2000, when new national planning guidance emphasized the importance of permeability for pedestrians in site design, and called for the 
creation of well-connected streets that avoid "introverted" dead-end layouts [36]. A subsequent design manual further emphasized the need to encourage walking and cycling through "networks of streets that provide permeability and connectivity to main destinations and a choice of routes," and presented a hierarchy of road users with pedestrians at the top [37]. In Ahmedabad, India, where recent development has been among the most connected of all Indian cities, boundaries of private landholdings are adjusted to allow for the creation of a regular grid as the city expands [38]. In neighboring Bhuj, post-earthquake planning efforts led to the interconnection of all culs-de-sac, motivated in part by the lack of access to dead-end streets that were blocked by falling rubble in the 2001 earthquake [39]. In China, while much post-1949 development consists of often-gated superblocks, guidelines issued by the Chinese State Council in 2016 call for a reversal of that approach, promoting a more fine-grained network and urging a cessation of enclosed (i.e. gated) residential neighborhoods [40].

Some policies are likely to be more internationally transferable than others. Fundamentally, however, the examples of Japan and many countries in the Middle East, along with the historical street patterns in Latin America, show that street-network sprawl is far from inevitable. Their experience suggests that building connected streets can achieve not just environmental goals, but contribute to vibrant, economically prosperous urban centers. The world has much to learn from cities and countries that have turned the corner and are building more connected street networks - and from those that, often with little fanfare, have been doing so all along.

\section{Materials and Methods}

We calculate properties named dendricity and sinuosity for street-network edges and properties named circuity and nodal degree associated with street-network nodes. These measures address both graph-theoretic and more geographic concepts of street-network connectivity. A summary measure, derived through principal components analysis and dubbed the Street-Network Disconnectedness index (SNDi), best captures the global, high-resolution variance of the constituent connectivity measures. Full details are provided in the SI accompanying [8]. Also described in [8] is a classification of all $\sim 4.1$ million 30 -arc second $\left(\sim 1 \mathrm{~km}^{2}\right)$ urban grid cells into eight empirical types using $k$-means cluster analysis.

We make use of two time series derived from satellite remote sensing data, the Global Human Settlement Layer (GHSL) [16] and the Atlas of Urban Expansion [41, 18], to classify each street segment as to (i) whether it forms part of a built-up development or not, and (ii) the time period when it was developed. The GHSL approach yields four epochs $(<1975,1975-1990,1990-1999$ and 2000-14), while the Atlas approach yields three $(<1990$, 1990-1999 and 2000-13). Our method makes use of the permanence of roads, once built. However, we also validate our approach to assigning development dates using an independent method available in the USA [10], and through analyzing the consistency of the time series developed through GHSL and the Atlas methods (see SI).

The majority of our analysis employs the time series from GHSL, an open-data project pro- 
viding global spatial information about the human presence on the planet over time [16]. Data are available online (http: / / ghsl.jrc.ec.europa.eu). We use the built-up grid which is derived from analysis of Landsat image collections, and provides built-up year classifications with approximately $38 \mathrm{~m}$ resolution. Pixels are classified as follows: land not built-up in any epoch; built-up from 2000 to 2014 epochs; built-up from 1990 to 2000 epochs; built-up from 1975 to 1990 epochs; built-up before 1975 epoch. For computational reasons, we aggregate to $306 \mathrm{~m}$ resolution, and calculate the built-up year of the aggregated grid cells as the modal builtup year of individual pixels. Each edge and node is assigned the modal epoch of the intersecting pixels.

Our city-level aggregations utilize the time series from Atlas of Urban Expansion [41, 18], an open-data online database of city boundaries. The Atlas includes a sample of 200 of the world's metropolitan areas that had 100,000 people or more in 2010 and provides urban extents at three time points: circa 1990, circa 2000, and circa 2013. We calculate spatial differences between successive time points in order to generate boundaries for new development during the periods 1990-1999 and 2000-2013. We then aggregate our street-level metrics to these regions to characterize development over time in these cities.

The SI reports results for all areas (including non-urban), and discusses our methods in detail, including extensive robustness checks. Complete open-source computer code for quantifying street-network sprawl and reproducing our results are, along with our resulting dataset, linked from the SI.

\section{References}

[1] International Energy Agency. World Energy Outlook 2017. Technical report, Organization for Economic Cooperation and Development/International Energy Agency, Paris, 2017.

[2] IPCC. Summary for policymakers. Technical report, Cambridge, 2014.

[3] Felix Creutzig, Patrick Jochem, Oreane Y Edelenbosch, Linus Mattauch, Detlef P van Vuuren, David McCollum, and Jan Minx. Transport: A roadblock to climate change mitigation? Science, 350(6263):911-2, Nov 2015.

[4] Felix Creutzig. Evolving Narratives of Low-Carbon Futures in Transportation. Transport Reviews, 36(3):341-360, 2016.

[5] Reid Ewing and Robert Cervero. Travel and the Built Environment. Journal of the American Planning Association, 76(3):265-294, 2010.

[6] K.C. Seto, S. Dhakal, A. Bigio, H. Blanco, G.C. Delgado, D. Dewar, L. Huang, A. Inaba, A. Kansal, S. Lwasa, J.E. McMahon, D.B. Müller, J. Murakami, H. Nagendra, and 
A. Ramaswami. Human settlements, infrastructure and spatial planning. In O. Edenhofer, R. Pichs-Madruga, Y. Sokona, E. Farahani, S. Kadner, K. Seyboth, A. Adler, I. Baum, S. Brunner, P. Eickemeier, B. Kriemann, J. Savolainen, S. Schlmer, C. von Stechow, T. Zwickel, and J.C. Minx, editors, Climate Change 2014: Mitigation of Climate Change. Contribution of Working Group III to the Fifth Assessment Report of the Intergovernmental Panel on Climate Change, chapter 12. Cambridge University Press, 2014.

[7] Felix Creutzig, Giovanni Baiocchi, Robert Bierkandt, Peter-Paul Pichler, and Karen C. Seto. Global typology of urban energy use and potentials for an urbanization mitigation wedge. Proceedings of the National Academy of Sciences, 112(20):201315545, 2015.

[8] Christopher Barrington-Leigh and Adam Millard-Ball. A global assessment of street network sprawl. Under review at PLOS ONE, 2019.

[9] Christopher Kennedy, Julia Steinberger, Barrie Gasson, Yvonne Hansen, Timothy Hillman, Miroslav Havranek, Diane Pataki, Aumnad Phdungsilp, Anu Ramaswami, and Gara Villalba Mendez. Greenhouse Gas Emissions from Global Cities. Environmental Science \& Technology, 43:7297-7302, 2009.

[10] Christopher Barrington-Leigh and Adam Millard-Ball. A century of sprawl in the United States. Proceedings of the National Academy of Sciences, 112(27):8244-8249, 2015.

[11] Sarah Rock, Aoife Ahern, and Brian Caulfield. The economic boom, bust and transport inequity in suburban Dublin, Ireland. Research in Transportation Economics, 57:32 - 43, 2016.

[12] Brian Caulfield and Aoife Ahern. The green fields of Ireland: The legacy of Dublin's housing boom and the impact on commuting. Case Studies on Transport Policy, 2(1):20 27, 2014.

[13] Harald Leisch. Gated communities in Indonesia. Cities, 19(5):341-350, 2002.

[14] Christien Klaufus. Watching the city grow: remittances and sprawl in intermediate Central American cities. Environment and Urbanization, 22(1):125-137, 2010.

[15] Fernando Castillo Cabrera and Dagmar Haase. Guatemala City: A socio-ecological profile. Cities, 72:379 - 390, 2018.

[16] Martino Pesaresi, Guo Huadong, Xavier Blaes, Daniele Ehrlich, Stefano Ferri, Lionel Gueguen, Matina Halkia, Mayeul Kauffmann, Thomas Kemper, Linlin Lu, et al. A global human settlement layer from optical HR/VHR RS data: concept and first results. IEEE Journal of Selected Topics in Applied Earth Observations and Remote Sensing, 6(5):21022131, 2013. 
[17] World Bank. World Bank Open Data, 2016. https://blogs.worldbank.org/opendata/newcountry-classifications-2016.

[18] Shlomo Angel, Alejandro M. Blei, Jason Parent, Patrick Lamson-Hall, Nicolás Galarza Sánchez, with Daniel L. Civco, Rachel Qian Lei, and Kevin Thom. Atlas of Urban Expansion - 2016 Edition: Volume 1: Areas and Densities. NYU Urban Expansion Program at New York University, UN-Habitat, and the Lincoln Institute of Land Policy, 102016.

[19] Peter Newman and Jeffrey Kenworthy. Sustainability and Cities. Overcoming Automobile Dependence. Island Press, Washington, DC, 1999.

[20] Michael E Lewyn. Sprawl in Canada and the United States. Urban Lawyer, 44:85-133, 2012.

[21] Marjo Kasanko, José I. Barredo, Carlo Lavalle, Niall McCormick, Luca Demicheli, Valentina Sagris, and Arne Brezger. Are European cities becoming dispersed?: A comparative analysis of 15 European urban areas. Landscape and Urban Planning, 77(1):111 $-130,2006$.

[22] Phillip Y Lipscy and Lee Schipper. Energy efficiency in the Japanese transport sector. Energy Policy, 56:248-258, 2013.

[23] Robert C. Smith. Colonial Towns of Spanish and Portuguese America. Journal of the Society of Architectural Historians, 14(4):3-12, 1955.

[24] Christopher Barrington-Leigh and Adam Millard-Ball. The world's user-generated road map is more than 80\% complete. PLOS ONE, 12(8):1-20, 082017.

[25] Manish Shirgaokar, Elizabeth Deakin, and Nicolae Duduta. Integrating building energy efficiency with land use and transportation planning in Jinan, China. Energies, 6(2):646661, 2013.

[26] Jiangyan Wang and Dongquan He. Sustainable urban development in China: challenges and achievements. Mitigation and Adaptation Strategies for Global Change, 20(5):665682, Jun 2015.

[27] A. Paolo Masucci, Kiril Stanilov, and Michael Batty. Limited Urban Growth: London's Street Network Dynamics since the 18th Century. PLoS ONE, 8(8):e69469, 2013.

[28] Rowland Atkinson and Sarah Blandy, editors. Gated Communities. Routledge, Abingdon, Oxon, 2006.

[29] Chris Barrington-Leigh and Adam Millard-Ball. More connected urban roads reduce US GHG emissions. Environmental Research Letters, 12(4):044008, 2017. 
[30] Wesley Marshall and Norman Garrick. Effect of Street Network Design on Walking and Biking. Transportation Research Record: Journal of the Transportation Research Board, 2198:103-115, 2010.

[31] Pavithra Parthasarathi, Hartwig Hochmair, and David Levinson. Street network structure and household activity spaces. Urban Studies, 52(6):1090-1112, July 2015.

[32] Deborah Salon, Marlon G. Boarnet, Susan Handy, Steven Spears, and Gil Tal. How do local actions affect VMT? A critical review of the empirical evidence. Transportation Research Part D: Transport and Environment, 17(7):495-508, October 2012.

[33] Alice Colsaet, Yann Laurans, and Harold Levrel. What drives land take and urban land expansion? A systematic review. Land Use Policy, 79:339 - 349, 2018.

[34] Philip L. Fradkin. The Great Earthquake and Firestorms of 1906. How San Francisco Nearly Destroyed Itself. University of California Press, Berkeley, 2005.

[35] Aliye Ahu Akgün and Tüzin Baycan. Gated communities in Istanbul: the new walls of the city. Town Planning Review, 83(1):87-109, 2011.

[36] Department for Transport, Local Government and the Regions and Commission for Architecture and the Built Environment. Better places to live by design. A companion guide to PPG3. Thomas Telford Publishing, London, 2001.

[37] Department for Transport. Manual for Streets. Thomas Telford Publishing, London, 2007.

[38] The Economist. Sprawls well. How one Indian city cracked the problem of urban sprawl, November 2018.

[39] Sweta Byahut and Jay Mittal. Using land readjustment in rebuilding the earthquakedamaged city of Bhuj, India. Journal of Urban Planning and Development, 143(1):05016012, 2017.

[40] Har Ye Kan, Ann Forsyth, and Peter Rowe. Redesigning China's superblock neighbourhoods: policies, opportunities and challenges. Journal of Urban Design, 22(6):757-777, 2017.

[41] Shlomo Angel, Alejandro M Blei, Daniel L Civco, and Jason Parent. Atlas of urban expansion. Lincoln Institute of Land Policy, Cambridge, MA, 2012. 


\title{
Supporting Information: Global trends towards urban street-network sprawl
}

\author{
March 2019 \\ DRAFT in revision/review: \\ please cite as OSF.io preprint \\ DOI:10.31219/osf.io/2cp5u \\ Christopher Barrington-Leigh ${ }^{1, \diamond}$, Adam Millard-Ball ${ }^{2, \diamond}$,
}

1 McGill University; Institute for Health and Social Policy; and McGill School of Environment; Montreal, Canada

2 University of California Santa Cruz; Environmental Studies Department; Santa Cruz, California

Authors are listed alphabetically and contributed equally to this work.

\section{Contents}

$\begin{array}{ll}\text { A Urban development time series } & 3\end{array}$

$\begin{array}{ll}\text { B Persistence } & 7\end{array}$

$\begin{array}{ll}\text { C Sensitivity analysis } & 9\end{array}$

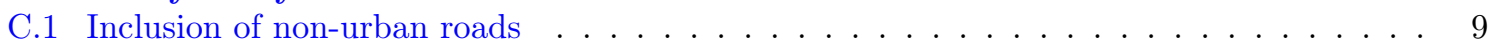

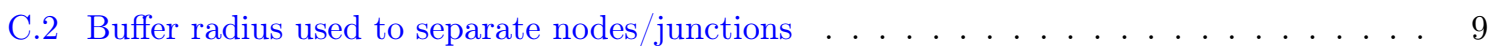

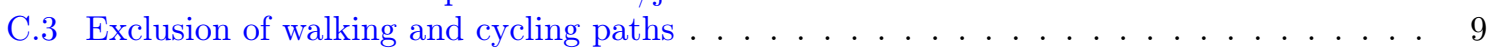

$\begin{array}{ll}\text { D Data and code release } & 12\end{array}$

$\begin{array}{ll}\text { E Citation and contact } & 12\end{array}$

F Supplemental reference book: results 12

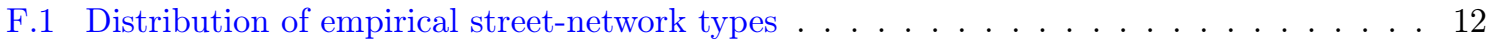

F.2 Trends and global distributions of key variables . . . . . . . . . . . . . . 15

F.3 Summary trend plots for selected street-network sprawl measures . . . . . . . . . . . . 16

F.4 Road growth rates and connectivity . . . . . . . . . . . . . . . . . 26

F.5 Countries ranked by urban street-network sprawl (SNDi) of recent road development . . 28

F.6 Cities ranked by urban street-network sprawl (SNDi) of recent road development . . . . 35

F.7 City maps . . . . . . . . . . . . . . . . . . . . . . . 42

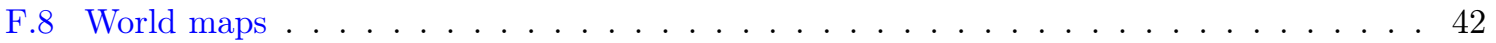

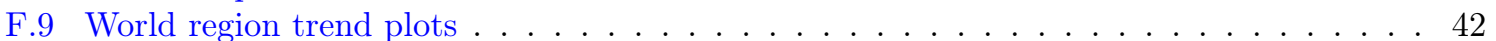

F.10 Country trend plots with sub-national regional distributions . . . . . . . . . . . 47

F.11 City trend plots (by region) $\ldots \ldots \ldots \ldots \ldots$

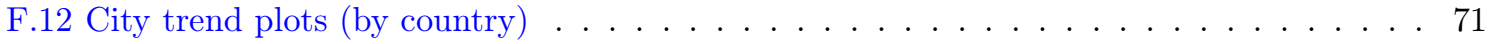




\section{List of Figures}

S1 Comparison of GHSL and Atlas . . . . . . . . . . . . . . . . . . . . 4

S2 Comparison of GHSL with parcel- and census-based measures, USA . . . . . . . . . . 5

S3 Validation of connectivity time series, using house construction dates . . . . . . . . . 6

S4 Path dependence in street-network sprawl . . . . . . . . . . . . . . . . . 8

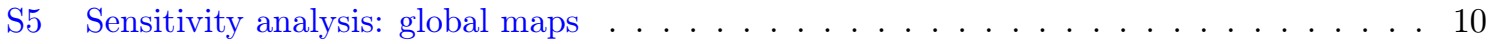

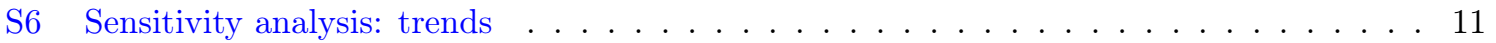

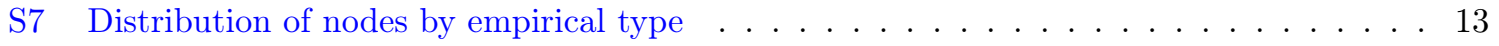

S8 Distribution of grid cells by empirical type . . . . . . . . . . . . . . . . . . 14

S9 Global shifts over time . . . . . . . . . . . . . . . . . . . . . 15

S10 Rate of road growth and SNDi. . . . . . . . . . . . . . . . 27

\section{List of Tables}

S1 Countries listed in order of recent urban street-network sprawl (SNDi) . . . . . . . . . 29

S2 Cities listed in order of their recent urban street-network sprawl (SNDi) $\ldots \ldots \ldots$ 


\section{A Urban development time series}

We obtain time-of-construction information from two sources, the Global Human Settlement Layer (GHSL) and the Atlas of Urban Expansion, described further in the main text. Here, we analyze the consistency of the development dates from each source, through comparing them to each other, and to our earlier work in the USA.

Figure S1 shows the consistency of our two data sources where they overlap. The GHSL dataset tends to assign an earlier year-built to each node, but the trends are consistent.

For the USA, we also compare the GHSL-based method of generating a time series to our earlier work, which used census and county parcel assessment data [Barrington-Leigh and Millard-Ball, 2015]. The census-based method covers the entire USA and assigns to each block group households' median report of the year when their house was constructed. The parcel-based method covers only about a third of the USA but makes use of county records' building construction date for every residential property in order to assign an original construction date for each street segment. As shown in Figure S2, the methods assign closely matching dates to road segments, even though the data sources are completely independent: one relies solely on remote sensing data, while the others rely on self-reported house construction dates. For years through 1999, the inter-quartile range of the census- and parcel-data methods matches GHSL almost exactly. For the most recent period (2000-13), while the median years align (solid red lines), the inter-quartile range does not fully overlap. This is likely due to aggregation bias in census geography, as the block group boundaries do not reflect more recent development.

Consistency in the time series of road network evolution translates into consistency in our main results, which concern the evolution of connectivity over time. Figure S3 presents comparisons of trends in mean degree and fraction of deadends, the two metrics used to characterize sprawl by BarringtonLeigh and Millard-Ball [2015], for the entire USA and for one metropolitan region with good coverage by parcel-based data. 

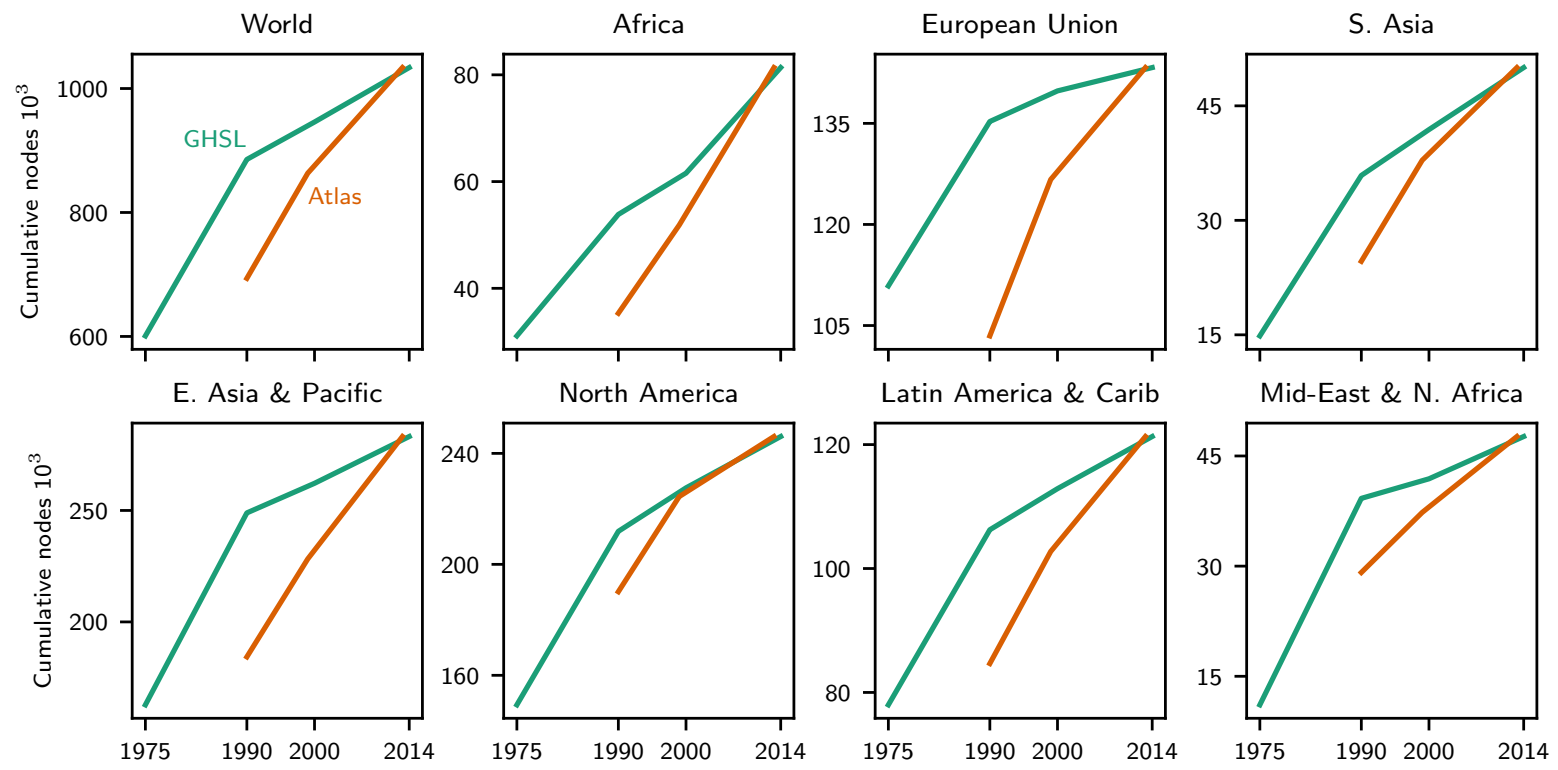

Figure S1: Comparison of GHSL and Atlas. Each plot shows the cumulative number of nodes within the Atlas cities, for the entire world and by select World Bank-defined regions. By construction, the cumulative number is equal in 2014. 


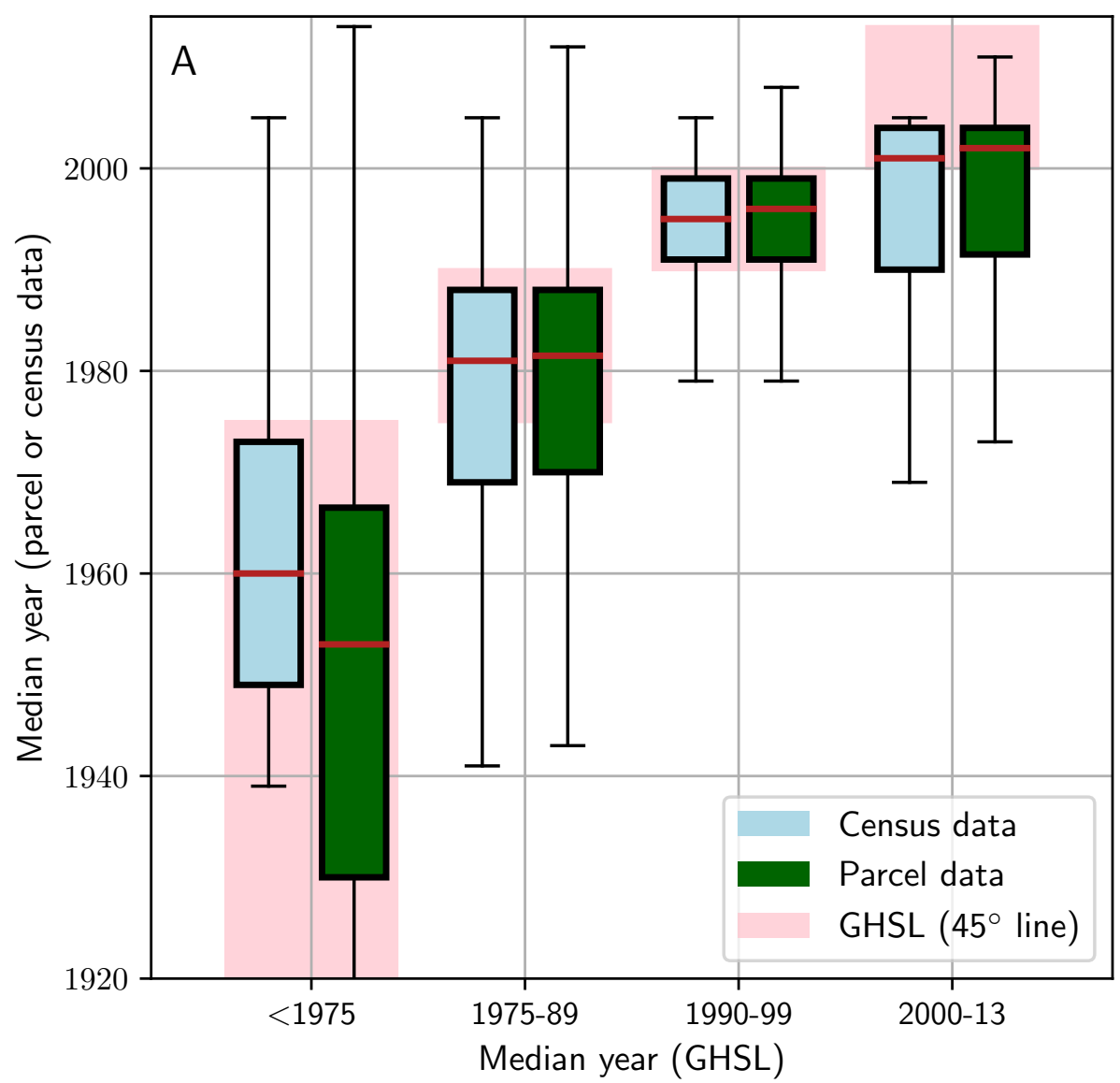

Figure S2: Comparison of GHSL with parcel- and census-based measures, USA. The units of analysis are census block groups in urban areas. We take the median GHSL year of each node with a block group, and compare that to the median year built of residential units within the block group ("census data"), and the median year of nodes within the block group, calculated from parcel assessment data on construction years ("parcel data"). Note that the census data have complete coverage, while the parcel-data sample accounts for about one-third of the urban US [Barrington-Leigh and Millard-Ball, 2015]. 

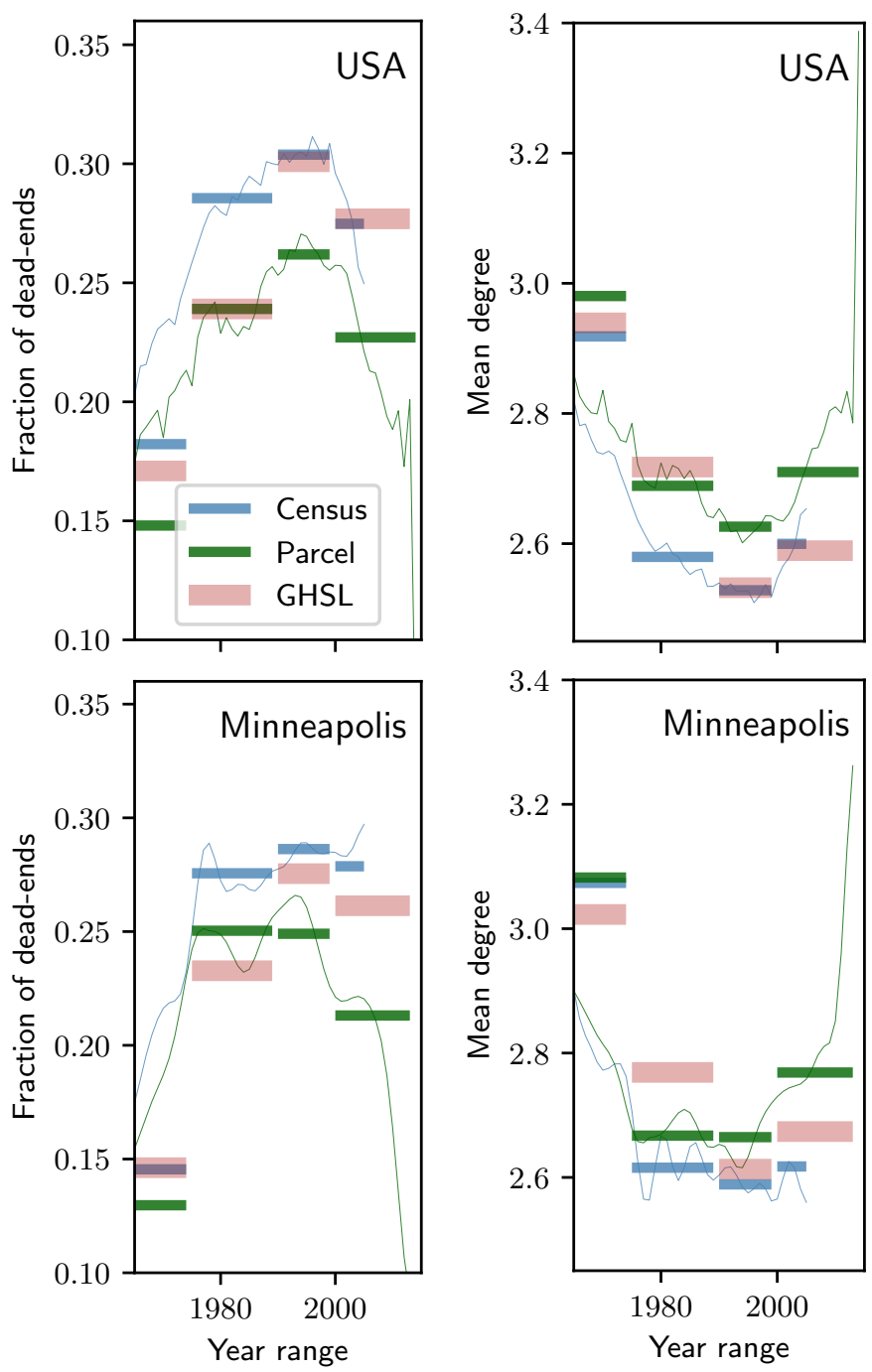

Figure S3: Validation of connectivity time series, using house construction dates. The time series of street-network sprawl (measured by the fraction of deadends) in our earlier work [BarringtonLeigh and Millard-Ball, 2015] is consistent with that generated by the remote-sensing method (GHSL) used in our global analysis. We show two connectivity measures calculated for the urban USA in our earlier work (top plots), as well as for the metropolitan area (Minneapolis-St Paul) where tax parcel data have the greatest coverage. For parcel and census data, thin lines show yearly averages (smoothed in the case of Minneapolis) while bars show period averages for comparison with GHSL. The first period average is the stock value up to 1974 . 
B Persistence 


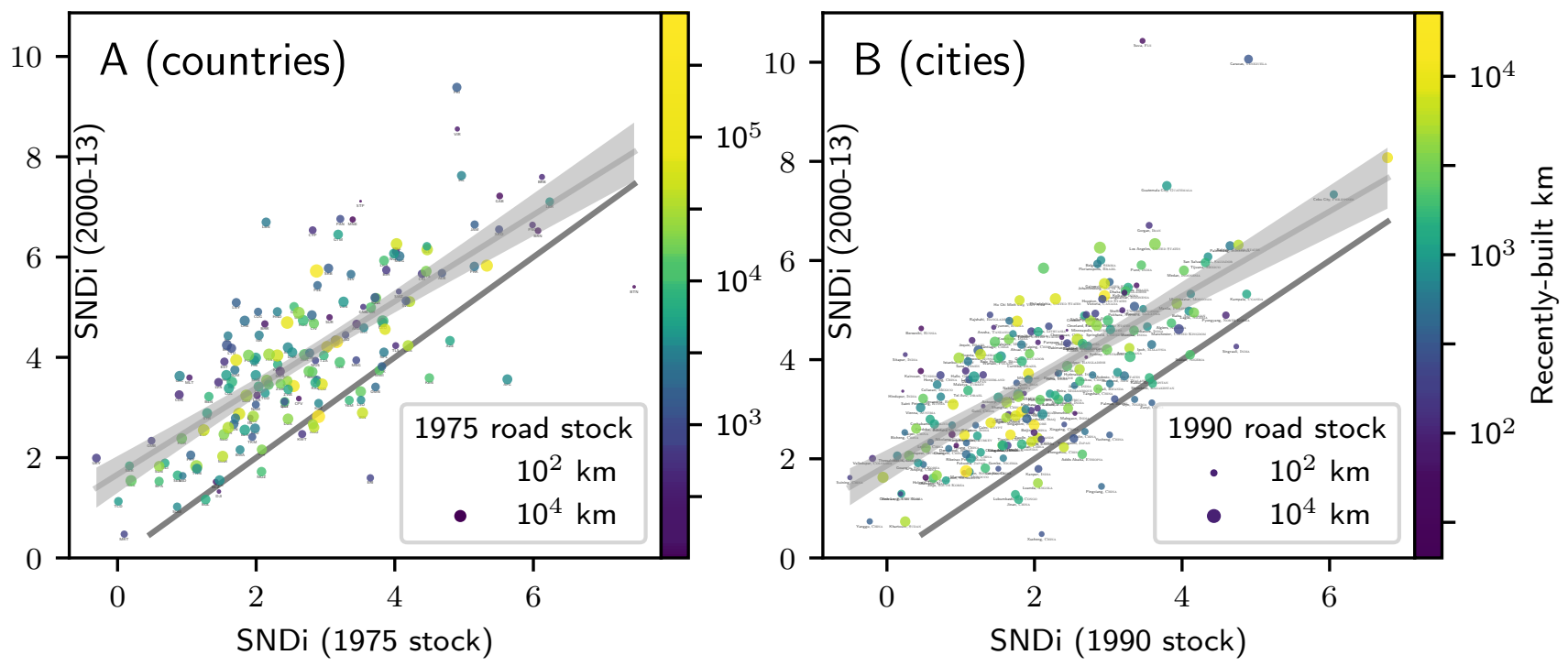

Figure S4: Path dependence in street-network sprawl. This figure is repeated from the main text, with the addition of small labels on cities and countries (three-letter ISO) visible by zooming in. SNDi of recent (2000-2013) construction is closely correlated with that of the earlier road stock in 1975 (countries, A) and 1990 (cities, B). Circle size denotes the length of original road stock, while color indicates the scale of recent construction. Only cities and countries with at least $100 \mathrm{~km}$ of new roads are shown. Linear fits characterizing the persistence relationship (gray shaded confidence region) are nearly parallel to the 45 degree line of perfect persistence (dark grey line) indicating a relatively uniform shift (on average $\Delta \mathrm{SNDi}=+1.56$ for cities, +1.26 for countries) away from earlier high connectivity. 


\section{Sensitivity analysis}

\section{C.1 Inclusion of non-urban roads}

While our preferred metrics are based only on the portions of road network we classify as urban, which account for $75 \%$ of nodes and $77 \%$ of edges (see Barrington-Leigh and Millard-Ball [2019] for details), we also calculate all measures on the full global set of nodes and metrics. Figure S5 and Figure S6 (top-right panels) compare this analysis to the corresponding figures from the main text (top-left panels), and show that including the remaining non-urban nodes and edges makes no qualitative, and only subtle quantitative, differences. There is a small rightward shift in the distribution of SNDi, shown in the inset to Figure S5, particularly in Russia and some countries in northern South America, indicating that non-urban streets tend to be less connected. The qualitative conclusions, however, are unchanged.

\section{C.2 Buffer radius used to separate nodes/junctions}

We reran our entire analysis using a radius of $7 \mathrm{~m}$ for merging intersections into nodes in our network representation (lower-left panels in Figure S5 and Figure S6). Aggregate findings are nearly identical to the $10 \mathrm{~m}$ version used in our primary analysis.

\section{C.3 Exclusion of walking and cycling paths}

Our main results aggregate the properties of only those edges and nodes that are accessible by motor vehicle. However, walking and cycling paths, as well as service roads such as driveways, are considered when calculating connectivity. For example, two adjacent culs-de-sac that are connected by a pedestrian path would not be considered deadends. (See Barrington-Leigh and Millard-Ball [2019] for details.) Figure S5 and Figure S6 (lower-right panels) show the results of an analysis that excludes all walking and cycling paths and driveways. Several countries and cities, particularly in the UK, Scandinavia and other parts of Europe, show substantially higher SNDi when the extra paths are completely excluded, indicating that such paths make a major contribution to the connectivity of the street network. The increase in SNDi in London is particularly marked. The discussion in the main text elaborates on the implications for policy. 


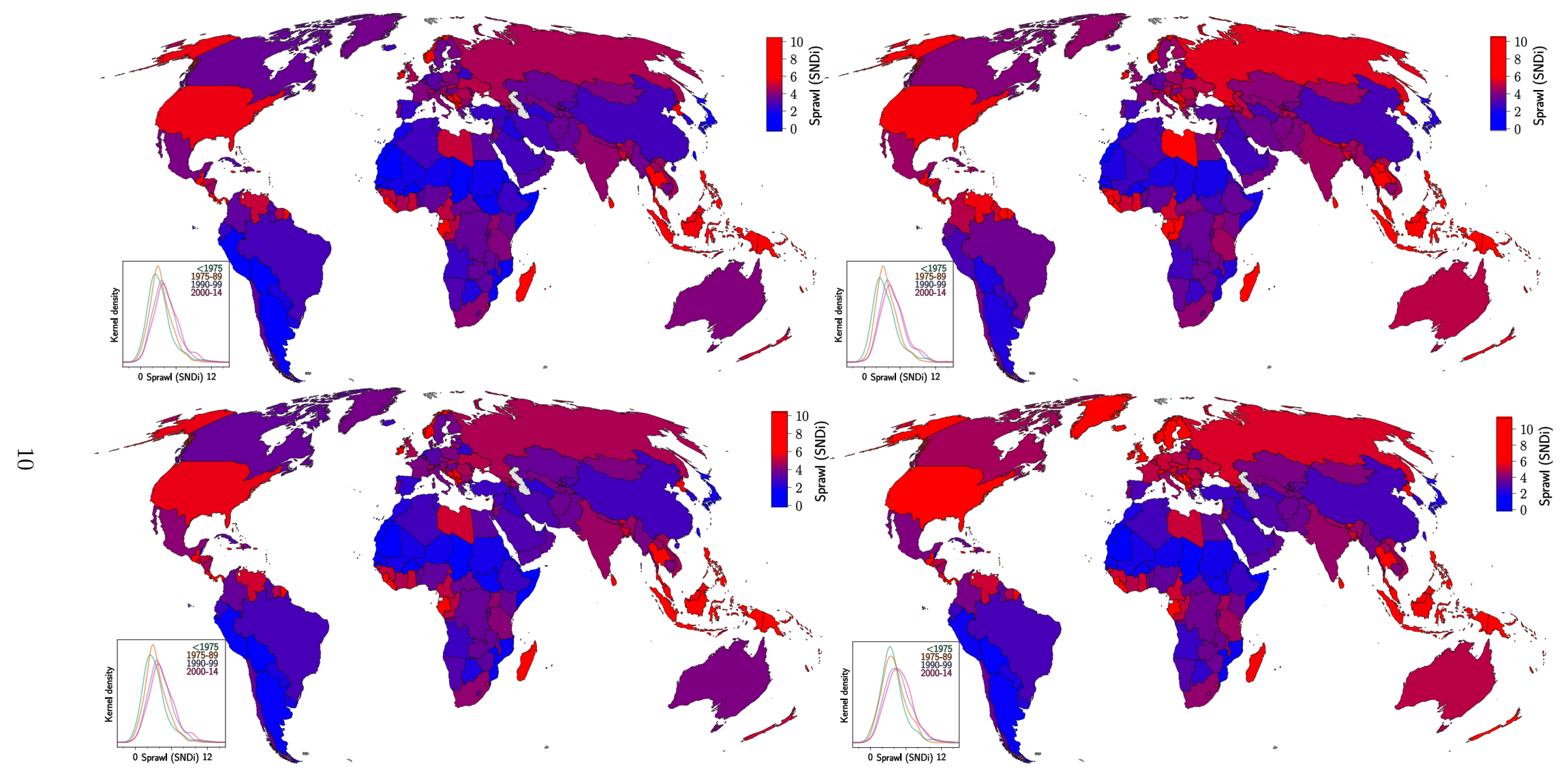

Figure S5: Sensitivity analysis for Figure 1 from the main text. The top-left map reproduces Figure 1, recent SNDi, from the main text. At top-right is a version calculated using all (i.e., urban and non-urban) nodes and edges, rather than only those we designate as "urban." The lower left map is a version calculated with an alternative intersection buffer radius $(7 \mathrm{~m})$, and the lower right one is calculated with the exclusion of walking and bicycling paths and service roads. 

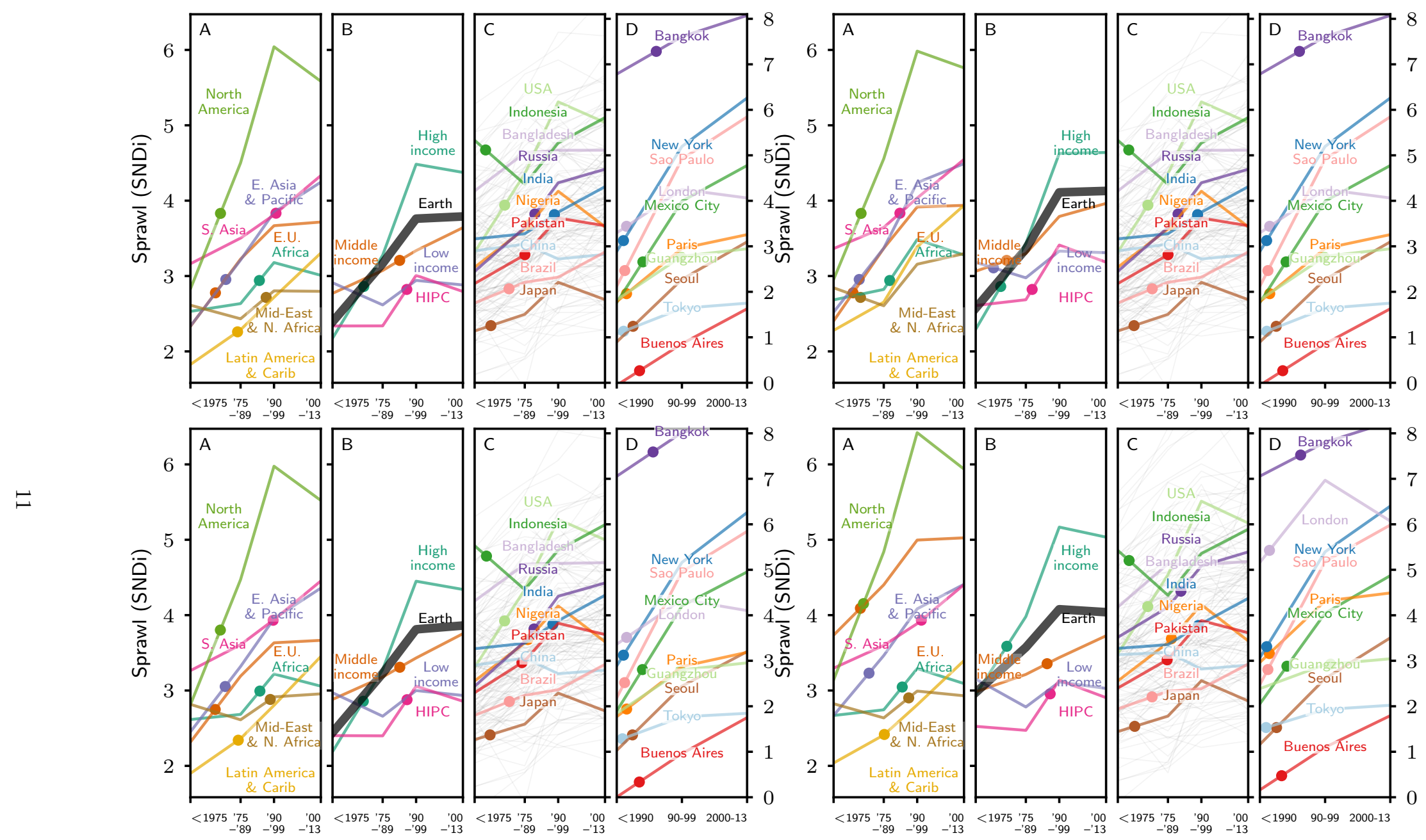

Figure S6: Top left: Sensitivity analysis for Figure 2 from the main text. The top-left set of panels reproduces Figure 2, trends in SNDi, from the main text. At top-right is a version calculated using all (i.e., urban and non-urban) nodes and edges, rather than only those we designate as "urban." The lower left panels are a version calculated with an alternative intersection buffer radius (7 m), and the lower right set are calculated with the exclusion of walking and bicycling paths and service roads. In each panel, the left two sub-plots share an ordinate scale, and the right two share a separate ordinate scale. 


\section{Data and code release}

All data used for this work are open. Freely available sources are listed under "Data Release" in Barrington-Leigh and Millard-Ball [2019] and in the Materials and Methods section of the main text. Our code to reproduce the data and analysis, which itself leverages exclusively open-source tools, is released under the GNU General Public License v3.0 as an open source project, permanently available at:

https://alum.mit.edu/www/cpbl/publications/draft2019sprawl/code

That site includes the following description of the code: https://gitlab.com/cpbl/global-sprawl-2019/blob/master/README.md

In addition, we provide the data corresponding to our street-network sprawl metrics aggregated to various levels described in more detail in Barrington-Leigh and Millard-Ball [2019]. Data are served from the following site:

https://alum.mit.edu/www/cpbl/publications/draft2019sprawl/data

Moreover, an interactive map interface to our high-resolution results, with links to data downloads, is available at http://sprawl.research.mcgill.ca/worldmap/.

\section{E Citation and contact}

For any use of the data or code, please cite the main paper.

For further questions, please contact:

Christopher Barrington-Leigh, McGill University

Adam Millard-Ball, University of California, Santa Cruz

\section{References}

Christopher Barrington-Leigh and Adam Millard-Ball. A century of sprawl in the United States. Proceedings of the National Academy of Sciences, 112(27):8244-8249, 2015.

Christopher Barrington-Leigh and Adam Millard-Ball. A global assessment of street network sprawl. Under review at PLOS ONE, 2019.

World Bank. World Bank Open Data, 2016. URL https://blogs.worldbank.org/ opendata/new-country-classifications-2016. https://blogs.worldbank.org/opendata/newcountry-classifications-2016.

\section{F Supplemental reference book: results}

The sections which follow contain more detailed tabular and graphical renditions of our findings. In addition, extensive online visualizations of our results are available at: https://alum.mit.edu/www/cpbl/publications/draft2019sprawl including an interactive map interface to our high-resolution results at: http://sprawl.research.mcgill.ca/worldmap/.

\section{F.1 Distribution of empirical street-network types}

Figure S7 shows the trends over time in the distribution of empirical street-network types by World Bank-defined regions; it is similar to the plot in the main text, but includes additional regions. Figure S8 repeats the figure, but shows the distribution according to the fraction of grid cells (rather than the fraction of nodes) that fall into each cluster. 

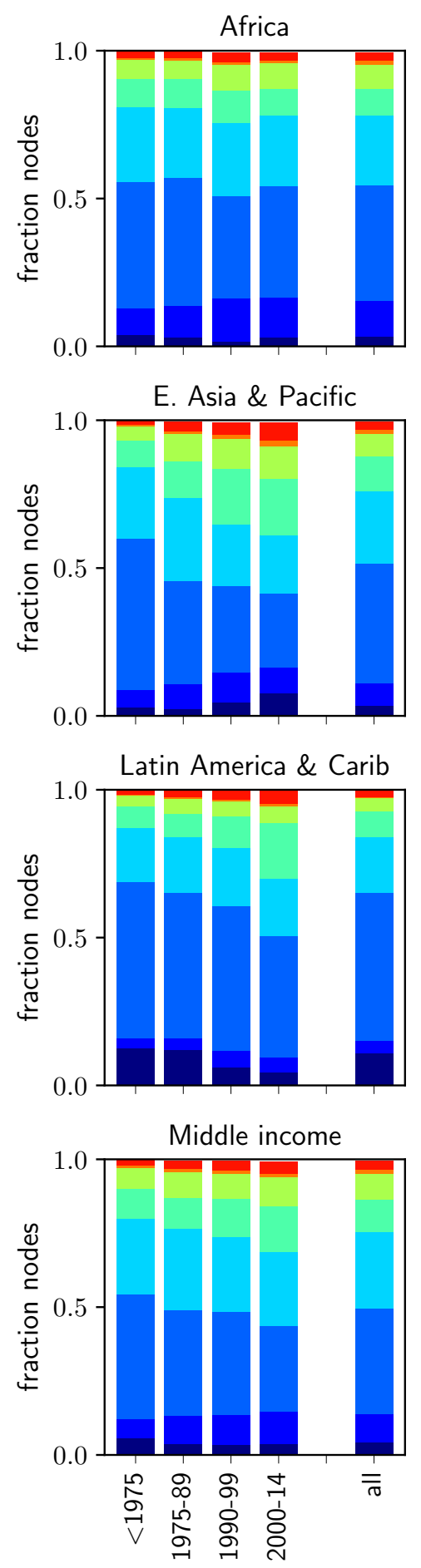
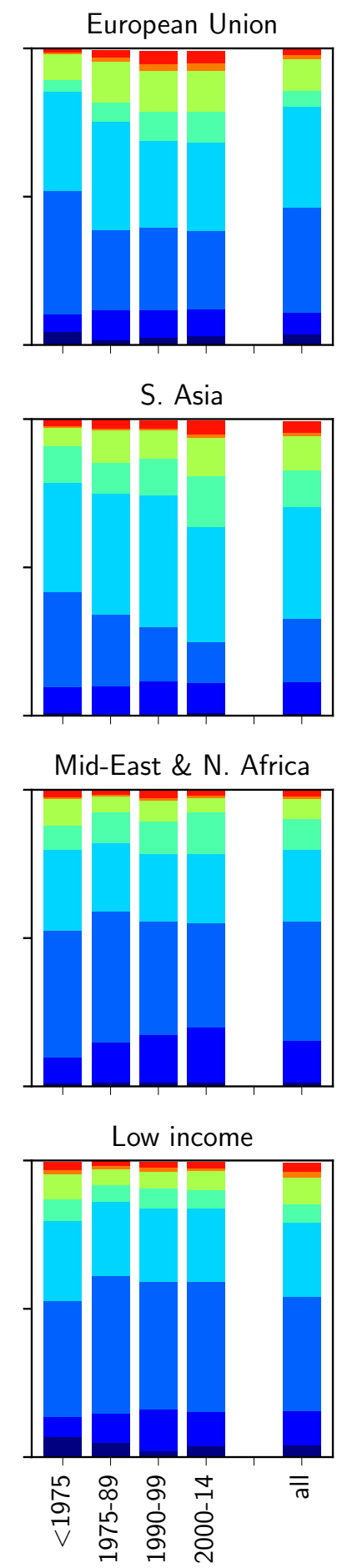

H: Disconnected

G: Dendritic

F: Dead ends

E: Circuitous

D: Broken grid

C: Irregular grid

B: Degree-3

A: Grid

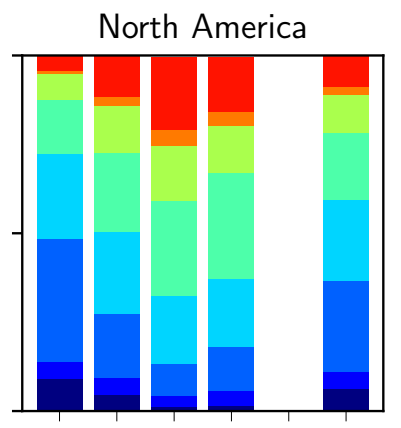

High income

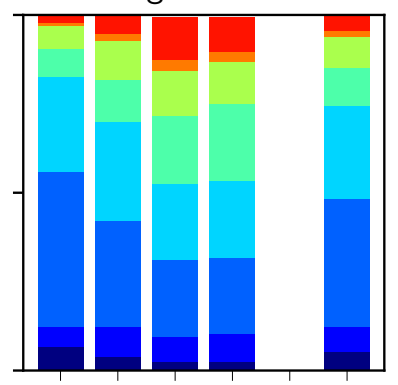

HIPC

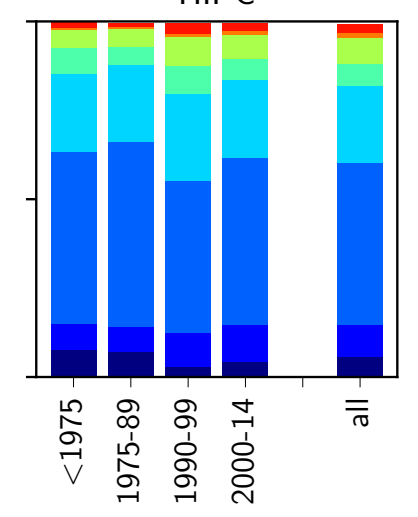

Figure S7: Distribution of nodes by empirical type, by World Bank-defined region and year. The bars represent the fraction of nodes in each type. 

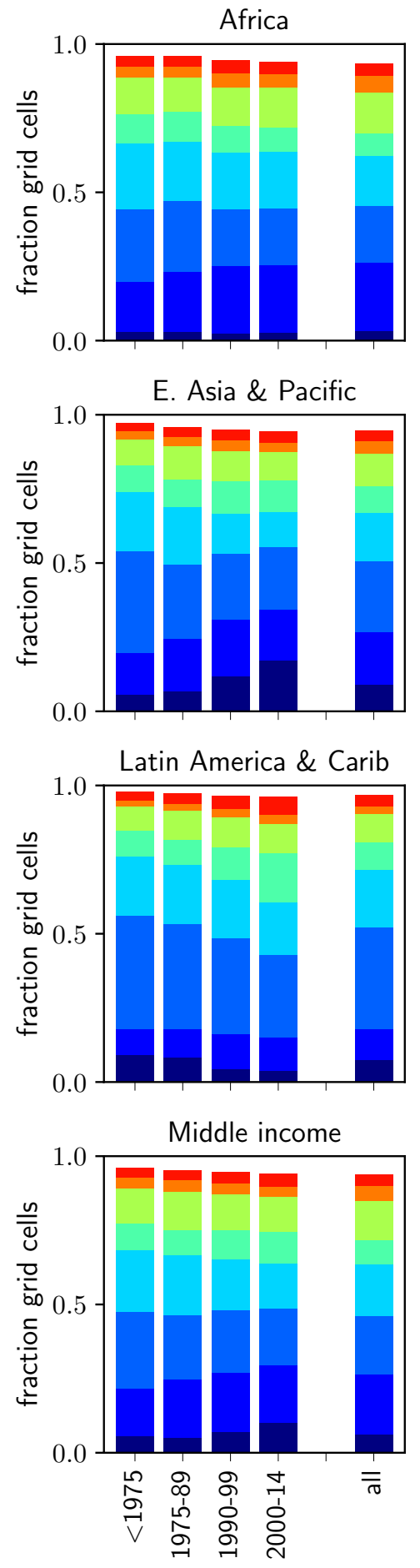
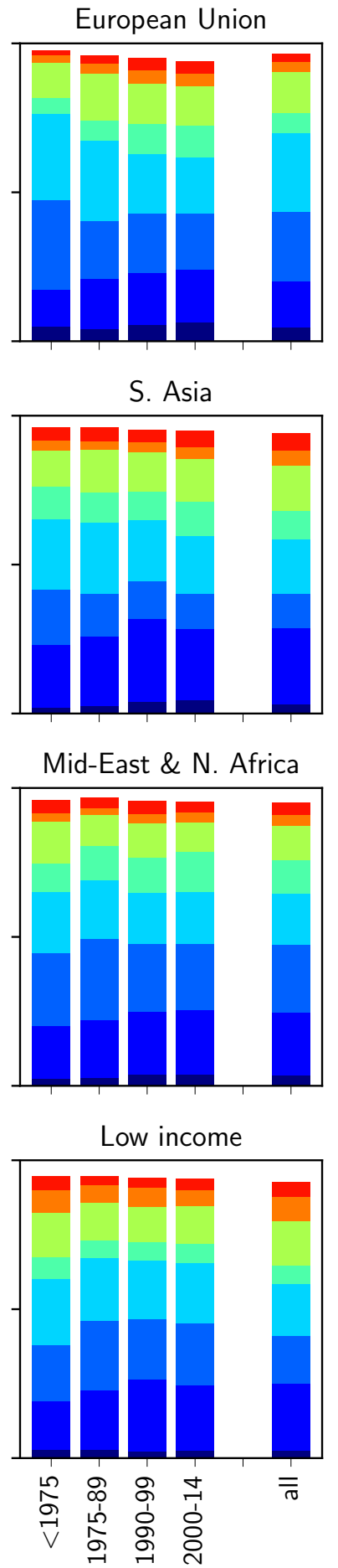

H: Disconnected

G: Dendritic

F: Dead ends

E: Circuitous

D: Broken grid

C: Irregular grid

B: Degree-3

A: Grid

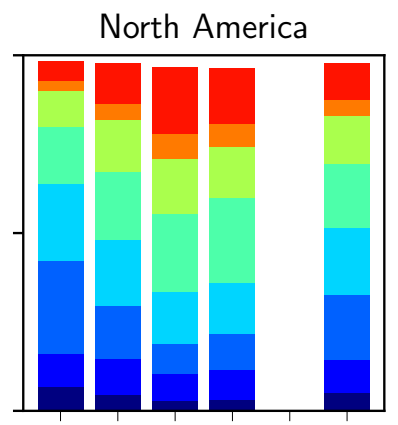

High income

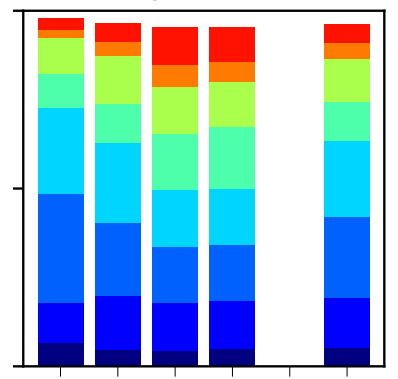

HIPC

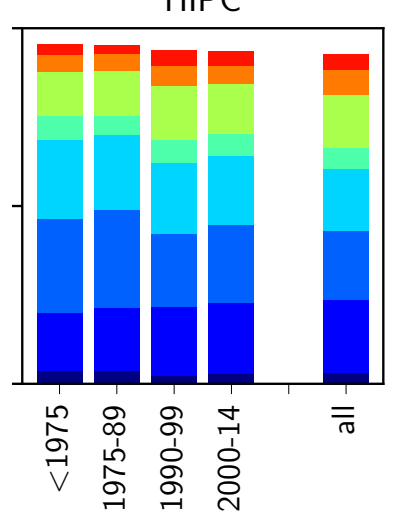

Figure S8: Distribution of grid cells by empirical type, by World Bank-defined region and year. The bars represent the fraction of grid cells in each type. (The two types that were dropped are not shown; hence, the bars do not add up to 100\%.) 

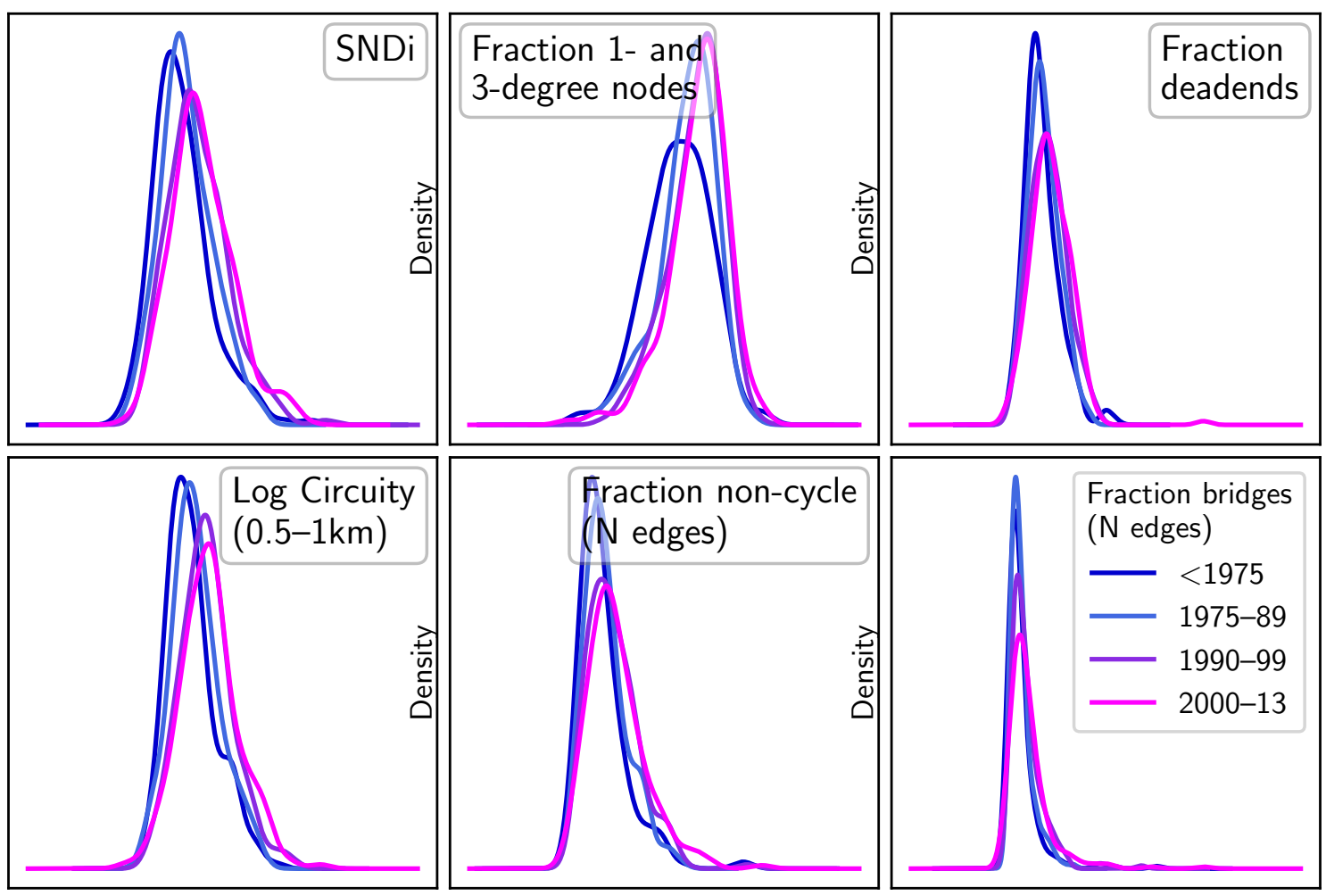

Figure S9: Global shifts over time. Curves show kernel density estimates of unweighted countrylevel means over urban nodes/edges, using built-up year classifications based on GHSL.

\section{F.2 Trends and global distributions of key variables}

Our analysis emphasizes our aggregate (first principal component) measure of street-network sprawl, SNDi. Figure S9 shows how the global distributions of SNDi and five of its individual connectivity measures have evolved over time. In each case, there is a significant shift towards lower connectivity, but with a partial leveling off in the latest time period. 


\section{F.3 Summary trend plots for selected street-network sprawl measures}

The following pages contain plots in the format of Figure 2 in the main text, but show trends of individual connectivity metrics making up our SNDi index. In each plot, the left two panels share a vertical axis, and the right two panels share a separate vertical axis. 


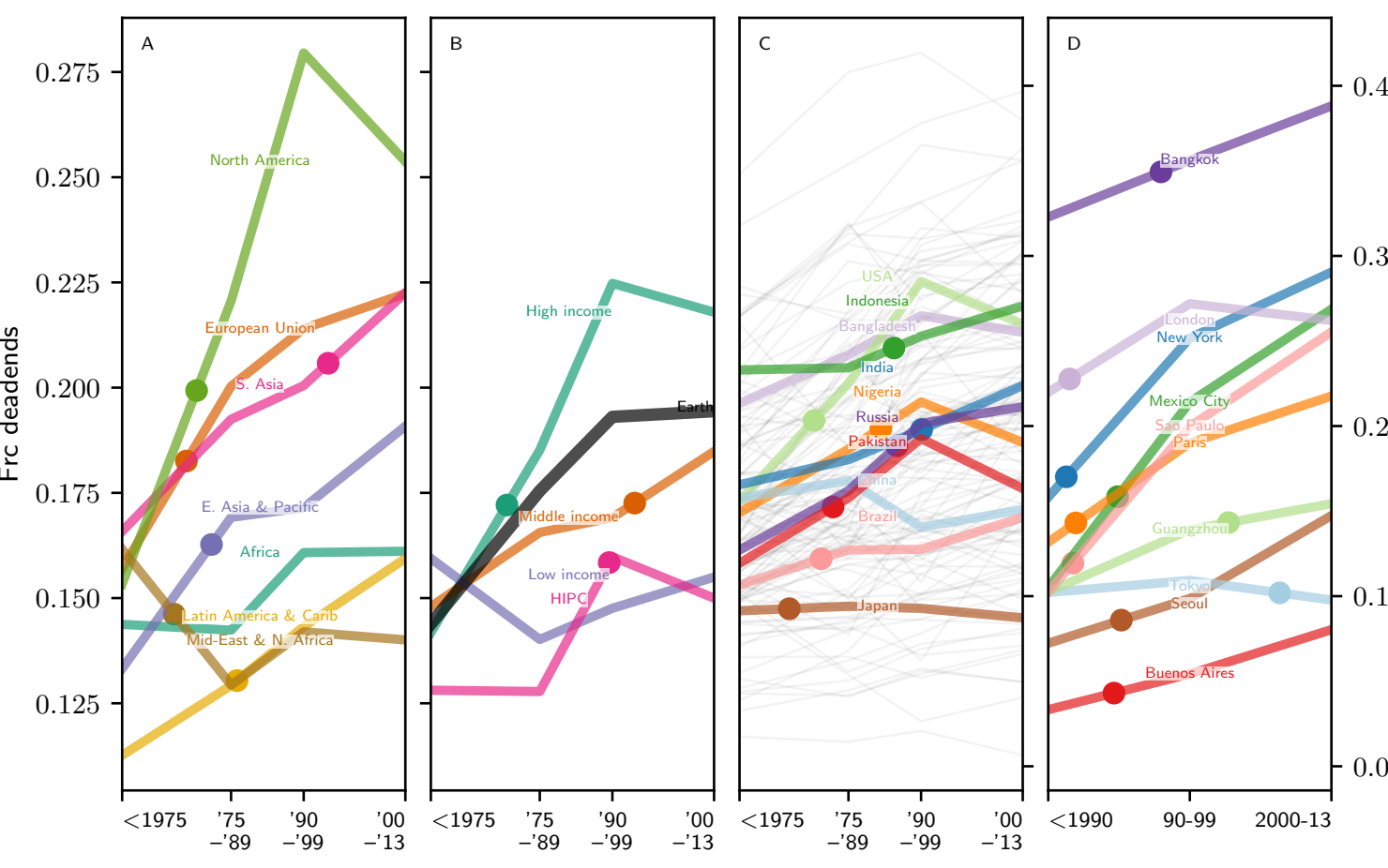




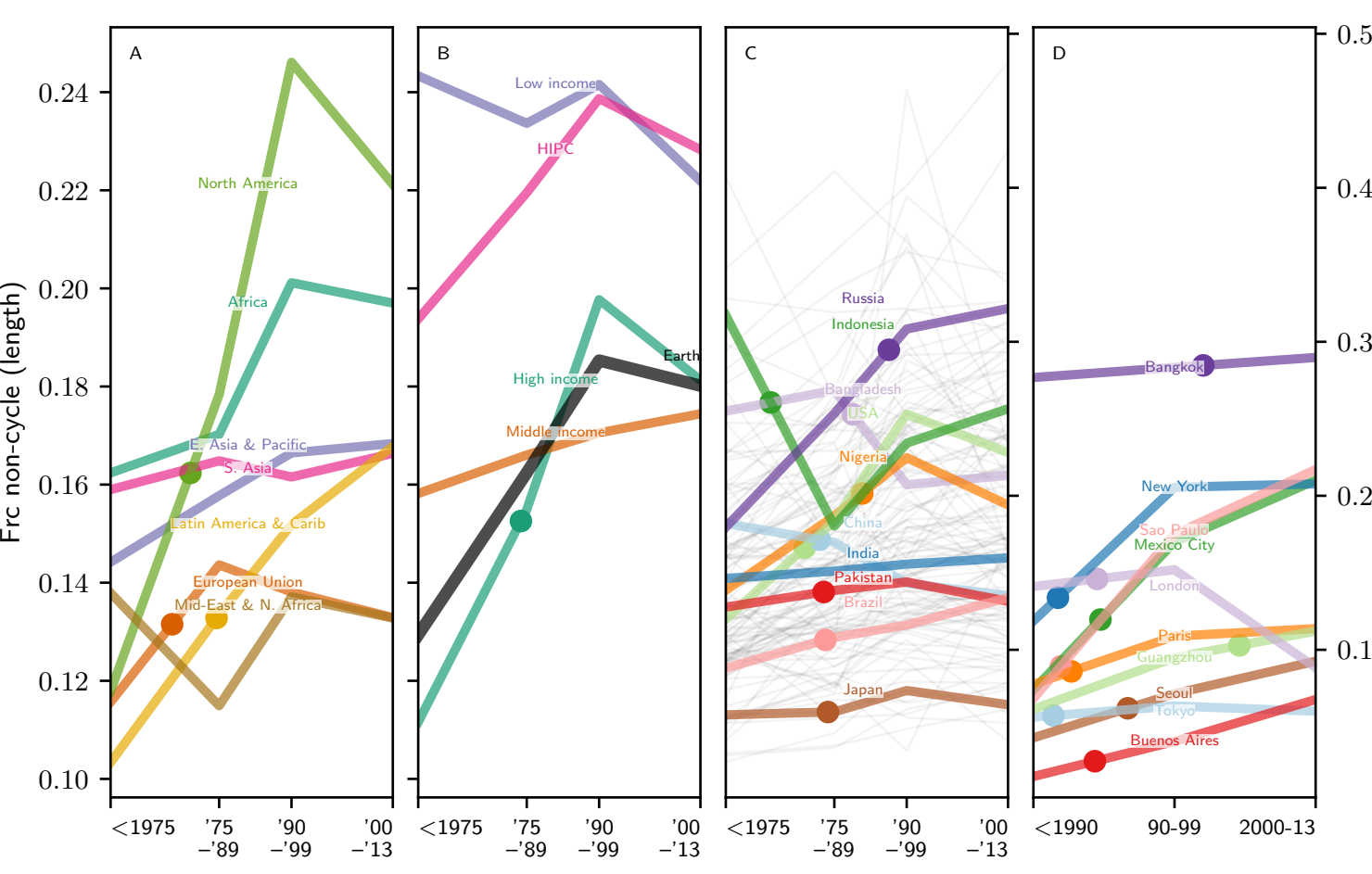




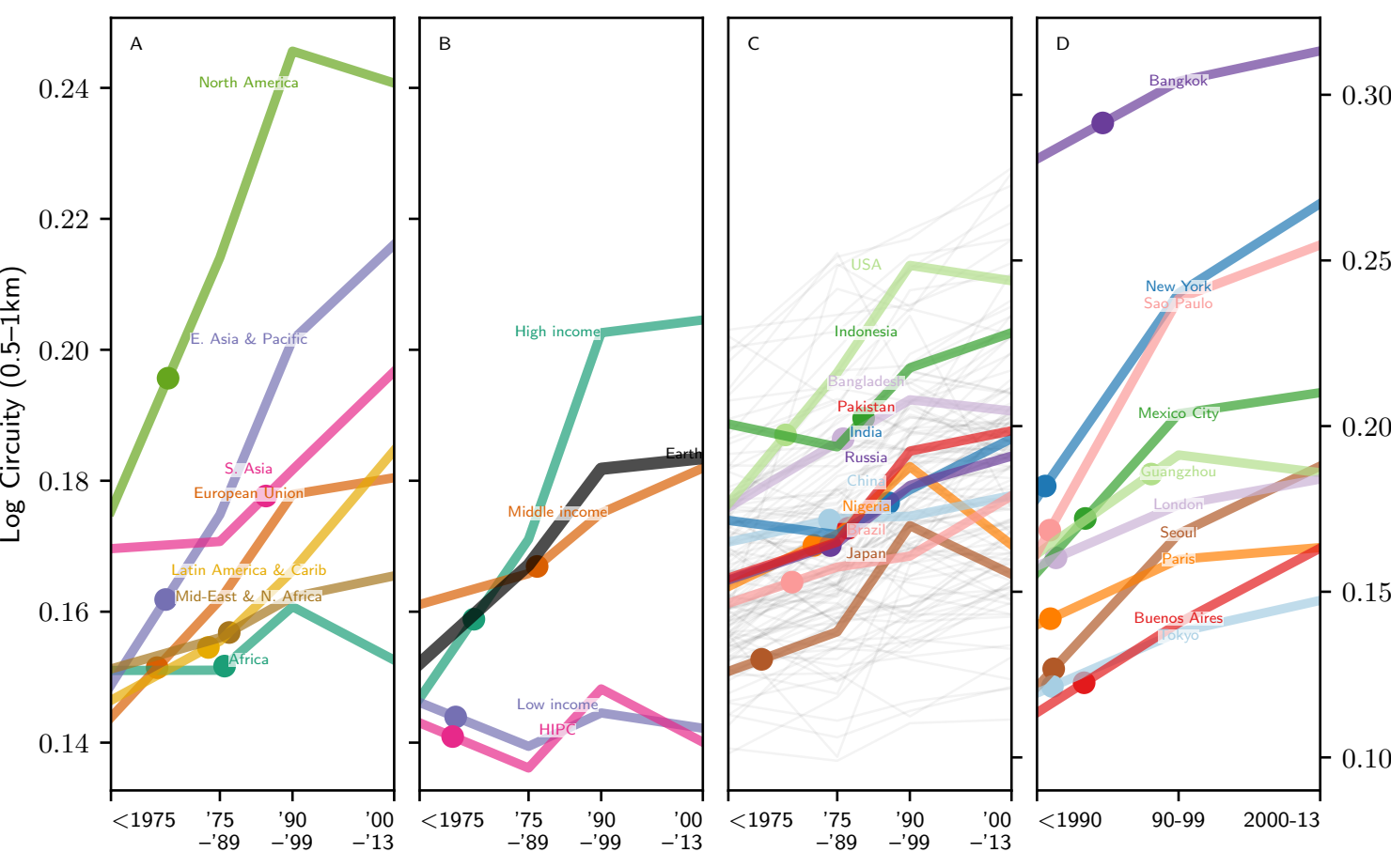




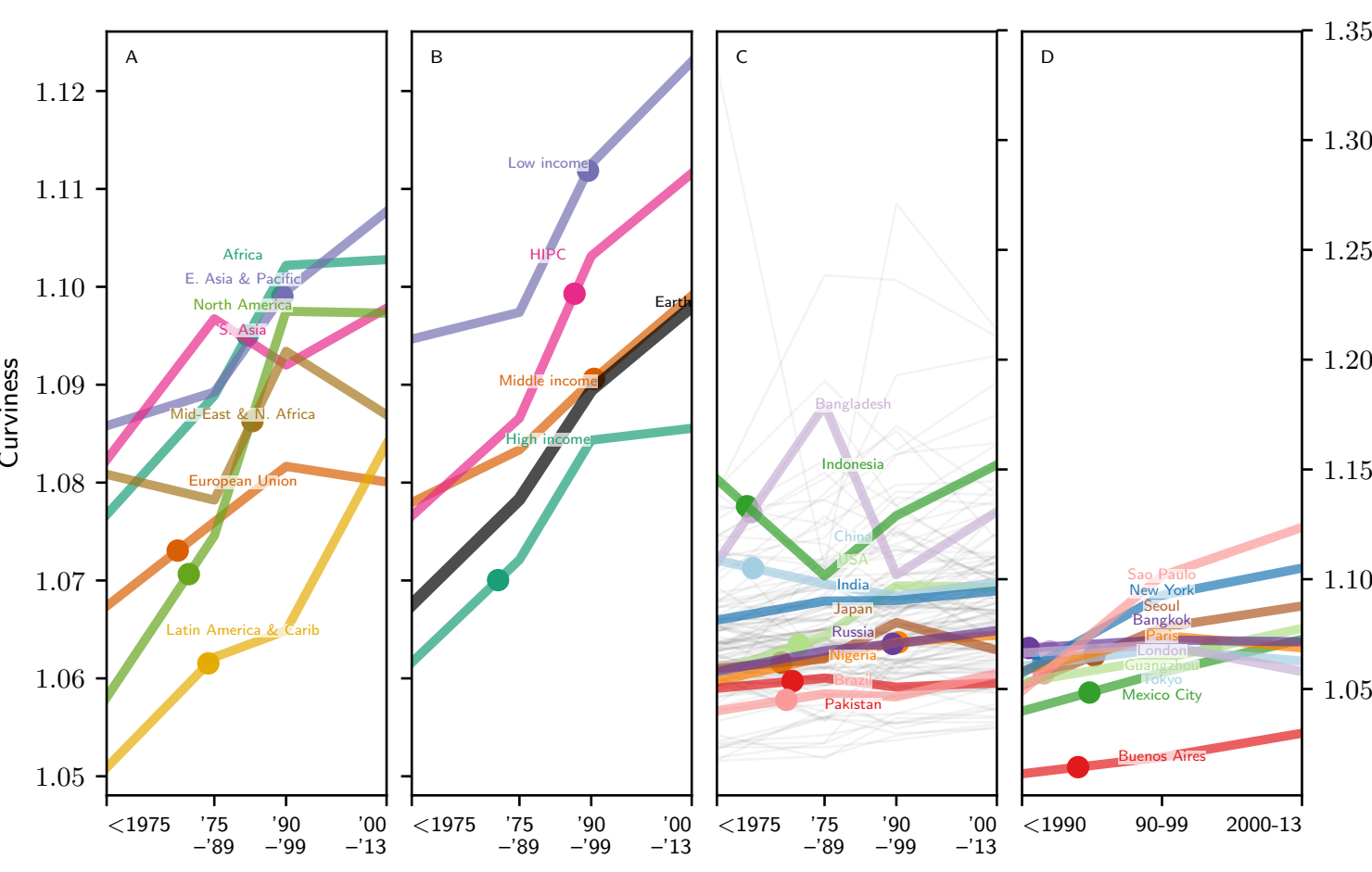




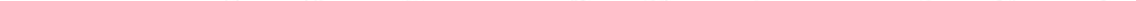




\section{F.4 Road growth rates and connectivity}

Our aggregations from individual road segments (edges) according to GHSL-determined epochs naturally produce estimates of the rate of road growth in each GADM region, grid cell, and Atlas of Urban Expansion city. Of course, these estimates are subject to the same uncertainties as our other calculations, namely the completeness of the OSM street database and the accuracy of GHSL and Atlas classifications.

Because global trends are driven by the size of additions to road stock, we explore the relationship between SNDi and the length of recent additions to the road stock, by city and by country (Figure S10 top row). There is no statistical relationship across cities, and only a weak one across countries. The countries with the largest road growth - China, India, United States, Nigeria, Indonesia, and South Africa - span the range of relatively low to relatively high SNDi. China's construction of 655,000 $\mathrm{km}$ of urban roads during this period is equal to nearly half the entire urban stock in the USA in 1975. Among cities, Bangkok and Tokyo stand out again; Bangkok is among the fastest growing cities, as well as an outlier in the low connectivity of its new street development. Meanwhile, Tokyo and Guangzhou are examples of equally fast or faster growth but with high connectivity. Houston appears to be a (fast-growing) low-connectivity city in the global picture.

In addition to analyzing SNDi against the magnitude of growth in roads, we compare it to the rate of growth. We define the growth rate of road networks as $R /(S-R)$, where $R$ is the addition to length in the most recent period (2000-2013) and $S$ is the length of the current stock. Figure S10 (bottom row) shows the relationship between recent SNDi and the road growth rate. Faster-growing cities tend to be building more-connected roads, perhaps largely due to the existence of rapidly-growing, initially-small cities in China. While a relationship holds also across countries, it does not hold statistically within any of our world regions (not shown). In terms of growth rate, the largest countries are in Africa. Similarly, as measured by road length per capita (not shown), African countries make up ten of the top 14 fastest builders. Notably, China is a significant investor in growing African infrastructure. 

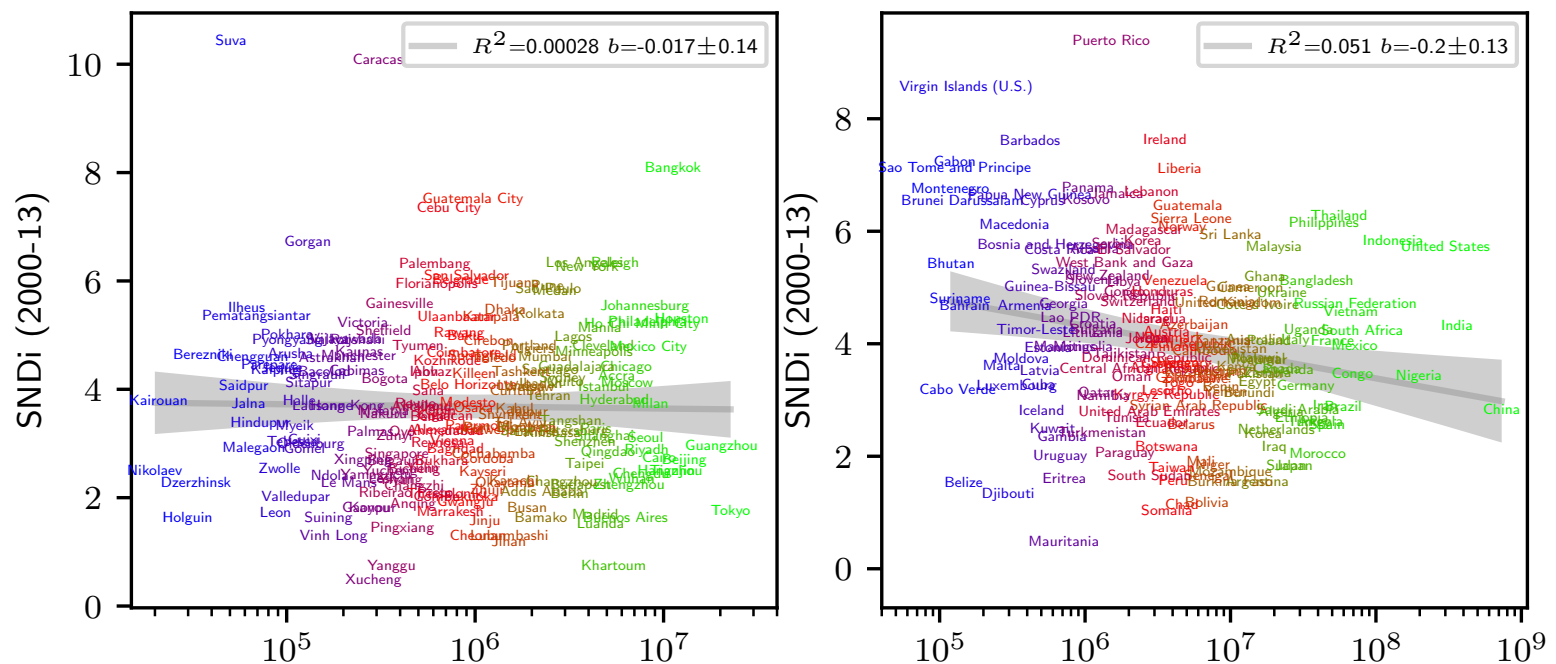

Recent road stock growth (m, 2000-13)

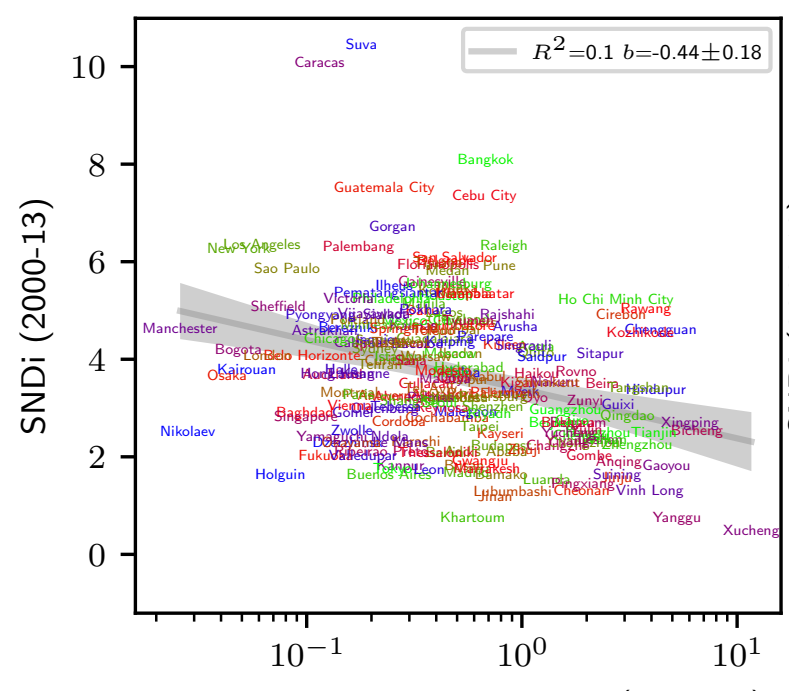

Recent road stock growth $(\mathrm{m}, 2000-13)$

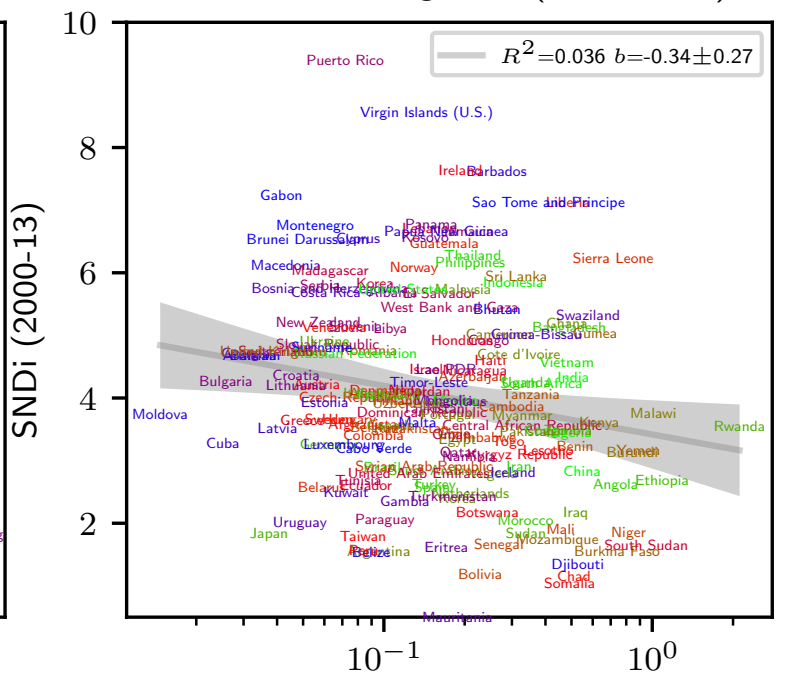

Recent road stock growth rate (2000-13)

Figure S10: Rate of road growth and SNDi. Relationships between recently-constructed (2000-2013) street-network sprawl and (top row) recent additions to road stock or (bottom row) recent growth rate of road stock. Cities are shown on the left, and countries on the right. Coefficients (b) from OLS fits are shown with 95\% confidence range. Colors in the lower panels are defined by the abscissa of the upper ones. 
F.5 Countries ranked by urban street-network sprawl (SNDi) of recent road development 
Table S1: Countries listed in order of recent urban streetnetwork sprawl (SNDi). Countries with large ( $>20 \mathrm{M})$ population are listed in bold.

\begin{tabular}{|c|c|c|c|c|c|c|c|c|c|c|c|c|c|c|c|}
\hline & \multicolumn{5}{|c|}{ Sprawl (SNDi) } & \multicolumn{5}{|c|}{ Nodal degree } & \multicolumn{5}{|c|}{ N(nodes) } \\
\hline & $<1975$ & $75-89$ & $90-99$ & $2000-13$ & Stock & $<1975$ & $75-89$ & 90-99 & 2000-13 & Stock & $<1975$ & 75-89 & 90-99 & $2000-13$ & Stock \\
\hline Puerto Rico & 4.9 & 7.7 & 8.9 & 9.4 & 6.5 & 2.7 & 2.4 & 2.3 & 2.3 & 2.5 & $54 \mathrm{k}$ & $47 \mathrm{k}$ & $12 \mathrm{k}$ & $8.2 \mathrm{k}$ & $120 \mathrm{k}$ \\
\hline $\begin{array}{l}\text { Virgin } \\
\text { (U.S.) }\end{array}$ & 4.9 & 7.9 & 8.1 & 8.6 & 7.4 & 2.8 & 2.4 & 2.4 & 2.4 & 2.5 & $1.1 \mathrm{k}$ & $2.5 \mathrm{k}$ & 880 & 690 & $5.3 \mathrm{k}$ \\
\hline $\begin{array}{l}\text { Trinidad and To- } \\
\text { bago }\end{array}$ & 6.1 & & 7.4 & 8.5 & 6.2 & 2.5 & & 2.3 & 2.3 & 2.5 & $28 \mathrm{k}$ & & 750 & 470 & $30 \mathrm{k}$ \\
\hline Ireland & 5.0 & 6.4 & 7.7 & 7.6 & 5.9 & 2.7 & 2.5 & 2.4 & 2.4 & 2.6 & $57 \mathrm{k}$ & $22 \mathrm{k}$ & $17 \mathrm{k}$ & $19 \mathrm{k}$ & $120 \mathrm{k}$ \\
\hline Barbados & 6.1 & & 7.2 & 7.6 & 6.4 & 2.5 & & 2.4 & 2.3 & 2.4 & $9.3 \mathrm{k}$ & & 960 & $2 \mathrm{k}$ & $13 \mathrm{k}$ \\
\hline Gabon & 5.5 & 5.8 & 5.8 & 7.2 & 5.9 & 2.6 & 2.5 & 2.5 & 2.4 & 2.5 & $3.3 \mathrm{k}$ & $8.1 \mathrm{k}$ & $2.3 \mathrm{k}$ & 500 & $15 \mathrm{k}$ \\
\hline Liberia & 6.2 & 7.7 & 7.6 & 7.1 & 6.9 & 2.6 & 2.4 & 2.4 & 2.4 & 2.5 & $13 \mathrm{k}$ & $2.4 \mathrm{k}$ & $2.4 \mathrm{k}$ & $3 \mathrm{k}$ & $22 \mathrm{k}$ \\
\hline Panama & 3.2 & 4.7 & 6.1 & 6.8 & 4.6 & 3.0 & 2.8 & 2.6 & 2.5 & 2.8 & $15 \mathrm{k}$ & $9.3 \mathrm{k}$ & $7.1 \mathrm{k}$ & $4.8 \mathrm{k}$ & $37 \mathrm{k}$ \\
\hline Montenegro & 3.4 & 5.0 & 5.9 & 6.7 & 4.5 & 2.9 & 2.6 & 2.5 & 2.3 & 2.7 & $3.7 \mathrm{k}$ & $3.7 \mathrm{k}$ & 310 & 340 & $8.6 \mathrm{k}$ \\
\hline Lebanon & 2.1 & 5.5 & 6.3 & 6.7 & 3.9 & 3.0 & 2.6 & 2.5 & 2.5 & 2.7 & $17 \mathrm{k}$ & $18 \mathrm{k}$ & $4 \mathrm{k}$ & $3.9 \mathrm{k}$ & $45 \mathrm{k}$ \\
\hline Jamaica & 5.2 & 6.3 & 6.3 & 6.6 & 5.6 & 2.6 & 2.5 & 2.5 & 2.5 & 2.6 & $19 \mathrm{k}$ & $5.5 \mathrm{k}$ & $3.8 \mathrm{k}$ & $3.2 \mathrm{k}$ & $33 \mathrm{k}$ \\
\hline Papua New Guinea & 6.0 & 5.5 & 7.1 & 6.6 & 6.5 & 2.6 & 2.6 & 2.4 & 2.7 & 2.6 & $3.7 \mathrm{k}$ & 870 & 270 & 250 & $6.2 \mathrm{k}$ \\
\hline Kosovo & 5.5 & 6.8 & 7.1 & 6.6 & 6.4 & 2.5 & 2.3 & 2.3 & 2.4 & 2.3 & $14 \mathrm{k}$ & $18 \mathrm{k}$ & $2.3 \mathrm{k}$ & $3.5 \mathrm{k}$ & $41 \mathrm{k}$ \\
\hline Cyprus & 2.8 & 4.0 & 5.6 & 6.5 & 4.2 & 2.8 & 2.7 & 2.6 & 2.5 & 2.7 & $6.7 \mathrm{k}$ & $26 \mathrm{k}$ & $4.8 \mathrm{k}$ & $2.9 \mathrm{k}$ & $41 \mathrm{k}$ \\
\hline Brunei Darussalam & 6.1 & 7.4 & 7.0 & 6.5 & 6.7 & 2.5 & 2.3 & 2.4 & 2.5 & 2.4 & $6.2 \mathrm{k}$ & $5.3 \mathrm{k}$ & $1.5 \mathrm{k}$ & 610 & $14 \mathrm{k}$ \\
\hline Guatemala & 3.2 & 4.7 & 6.1 & 6.5 & 4.6 & 3.0 & 2.9 & 2.7 & 2.7 & 2.9 & $32 \mathrm{k}$ & $41 \mathrm{k}$ & $12 \mathrm{k}$ & $11 \mathrm{k}$ & $110 \mathrm{k}$ \\
\hline Bahamas, The & 4.8 & 4.5 & 6.2 & 6.3 & 4.8 & 2.7 & 2.8 & 2.6 & 2.6 & 2.7 & $4.8 \mathrm{k}$ & $3.1 \mathrm{k}$ & 630 & 320 & $9.2 \mathrm{k}$ \\
\hline Thailand & 4.0 & 4.7 & 4.8 & 6.3 & 4.9 & 2.8 & 2.8 & 2.7 & 2.6 & 2.7 & $140 \mathrm{k}$ & $470 \mathrm{k}$ & $74 \mathrm{k}$ & $120 \mathrm{k}$ & $920 \mathrm{k}$ \\
\hline Sierra Leone & 4.5 & 6.6 & 6.0 & 6.2 & 5.7 & 2.7 & 2.5 & 2.5 & 2.5 & 2.6 & $8.7 \mathrm{k}$ & $3.2 \mathrm{k}$ & $2.6 \mathrm{k}$ & $9 \mathrm{k}$ & $25 \mathrm{k}$ \\
\hline Philippines & 4.5 & 5.3 & 5.6 & 6.1 & 5.4 & 3.0 & 2.8 & 2.8 & 2.8 & 2.8 & $130 \mathrm{k}$ & $200 \mathrm{k}$ & $51 \mathrm{k}$ & $59 \mathrm{k}$ & $500 \mathrm{k}$ \\
\hline Macedonia, FYR & 4.0 & 4.7 & 5.3 & 6.1 & 4.6 & 2.7 & 2.6 & 2.5 & 2.4 & 2.6 & $9 \mathrm{k}$ & $24 \mathrm{k}$ & $1.3 \mathrm{k}$ & 800 & $36 \mathrm{k}$ \\
\hline Norway & 4.0 & 4.8 & 5.7 & 6.1 & 4.6 & 2.9 & 2.7 & 2.6 & 2.6 & 2.8 & $62 \mathrm{k}$ & $57 \mathrm{k}$ & $10 \mathrm{k}$ & $19 \mathrm{k}$ & $170 \mathrm{k}$ \\
\hline Madagascar & 4.1 & 4.6 & 7.3 & 6.0 & 5.3 & 3.1 & 2.8 & 2.6 & 2.6 & 2.7 & $5.8 \mathrm{k}$ & $8.7 \mathrm{k}$ & $1.6 \mathrm{k}$ & $2.1 \mathrm{k}$ & $39 \mathrm{k}$ \\
\hline Sri Lanka & 3.8 & 5.9 & 5.4 & 5.9 & 5.5 & 2.7 & 2.5 & 2.6 & 2.5 & 2.5 & $22 \mathrm{k}$ & $78 \mathrm{k}$ & $8 \mathrm{k}$ & $26 \mathrm{k}$ & $150 \mathrm{k}$ \\
\hline Indonesia & 5.3 & 4.4 & 5.3 & 5.8 & 5.1 & 2.7 & 2.7 & 2.7 & 2.6 & 2.7 & $660 \mathrm{k}$ & $470 \mathrm{k}$ & $140 \mathrm{k}$ & $220 \mathrm{k}$ & $1.6 \mathrm{M}$ \\
\hline $\begin{array}{l}\text { Korea, Dem. } \\
\text { People's Rep. }\end{array}$ & 5.1 & 6.1 & 5.1 & 5.8 & 5.4 & 2.6 & 2.5 & 2.6 & 2.5 & 2.6 & $39 \mathrm{k}$ & $7.2 \mathrm{k}$ & $2.2 \mathrm{k}$ & $2.8 \mathrm{k}$ & $58 \mathrm{k}$ \\
\hline Serbia & 3.0 & 4.3 & 5.3 & 5.8 & 3.8 & 2.9 & 2.7 & 2.5 & 2.5 & 2.8 & $56 \mathrm{k}$ & $32 \mathrm{k}$ & $4.1 \mathrm{k}$ & $4.7 \mathrm{k}$ & $100 \mathrm{k}$ \\
\hline $\begin{array}{l}\text { Bosnia and Herze- } \\
\text { govina }\end{array}$ & 3.9 & 5.3 & 4.9 & 5.7 & 4.8 & 2.8 & 2.6 & 2.6 & 2.5 & 2.6 & $19 \mathrm{k}$ & $17 \mathrm{k}$ & $1.7 \mathrm{k}$ & $2 \mathrm{k}$ & $42 \mathrm{k}$ \\
\hline
\end{tabular}




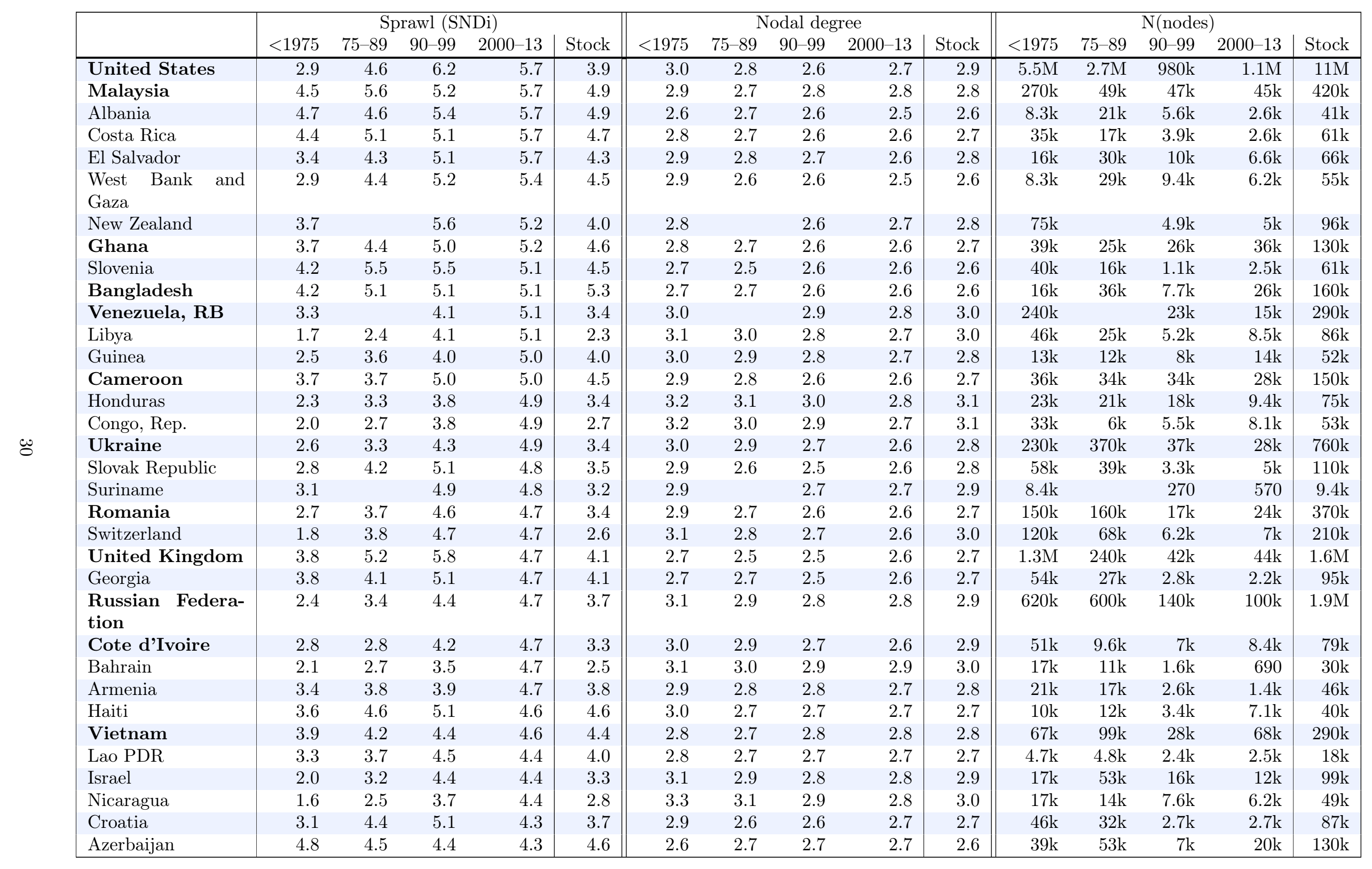




\begin{tabular}{|c|c|c|c|c|c|c|c|c|c|c|c|c|c|c|c|c|}
\hline \multirow{3}{*}{\multicolumn{2}{|c|}{ Trdis }} & \multicolumn{5}{|c|}{ Sprawl (SNDi) } & \multicolumn{5}{|c|}{ Nodal degree } & \multicolumn{5}{|c|}{$\mathrm{N}$ (nodes) } \\
\hline & & $<1975$ & $75-89$ & $90-99$ & $2000-13$ & Stock & $<1975$ & $75-89$ & $90-99$ & $2000-13$ & Stock & $<1975$ & $75-89$ & $90-99$ & $2000-13$ & Stock \\
\hline & & 3.2 & 3.3 & 3.8 & 4.3 & 3.7 & 2.9 & 2.9 & 2.8 & 2.7 & 2.8 & $510 \mathrm{k}$ & $740 \mathrm{k}$ & $320 \mathrm{k}$ & $550 \mathrm{k}$ & $2.4 \mathrm{M}$ \\
\hline \multirow{33}{*}{$\stackrel{\oplus}{\oplus}$} & Bulgaria & 1.6 & 1.7 & 4.1 & 4.2 & 1.8 & 3.1 & 3.0 & 2.7 & 2.7 & 3.0 & $98 \mathrm{k}$ & $110 \mathrm{k}$ & $4.2 \mathrm{k}$ & $4 \mathrm{k}$ & $230 \mathrm{k}$ \\
\hline & Uganda & 4.2 & 3.4 & 3.9 & 4.2 & 4.7 & 2.7 & 2.8 & 2.8 & 2.7 & 2.6 & $11 \mathrm{k}$ & $4.4 \mathrm{k}$ & $11 \mathrm{k}$ & $15 \mathrm{k}$ & $120 \mathrm{k}$ \\
\hline & South Africa & 3.0 & 3.8 & 3.7 & 4.2 & 3.6 & 3.0 & 2.9 & 2.9 & 2.8 & 2.9 & $170 \mathrm{k}$ & $240 \mathrm{k}$ & $110 \mathrm{k}$ & $110 \mathrm{k}$ & $660 \mathrm{k}$ \\
\hline & Austria & 2.5 & 3.4 & 4.6 & 4.2 & 2.9 & 3.0 & 2.8 & 2.7 & 2.7 & 2.9 & $150 \mathrm{k}$ & $76 \mathrm{k}$ & $13 \mathrm{k}$ & $13 \mathrm{k}$ & $260 \mathrm{k}$ \\
\hline & Lithuania & 1.6 & 2.7 & 3.7 & 4.2 & 2.9 & 3.2 & 3.0 & 2.8 & 2.8 & 2.9 & $16 \mathrm{k}$ & $15 \mathrm{k}$ & $3.6 \mathrm{k}$ & $1.9 \mathrm{k}$ & $57 \mathrm{k}$ \\
\hline & Nepal & 3.8 & 3.2 & 2.9 & 4.1 & 4.0 & 2.8 & 2.8 & 2.9 & 2.7 & 2.7 & $19 \mathrm{k}$ & $9.6 \mathrm{k}$ & $3.6 \mathrm{k}$ & $5.3 \mathrm{k}$ & $63 \mathrm{k}$ \\
\hline & Denmark & 2.5 & 3.1 & 3.6 & 4.1 & 2.9 & 2.9 & 2.8 & 2.8 & 2.7 & 2.9 & $130 \mathrm{k}$ & $77 \mathrm{k}$ & $9.7 \mathrm{k}$ & $19 \mathrm{k}$ & $240 \mathrm{k}$ \\
\hline & Jordan & 2.8 & 2.6 & 3.5 & 4.1 & 3.0 & 3.0 & 3.0 & 2.8 & 2.8 & 2.9 & $5.4 \mathrm{k}$ & $56 \mathrm{k}$ & $13 \mathrm{k}$ & $11 \mathrm{k}$ & $93 \mathrm{k}$ \\
\hline & Italy & 2.2 & 3.5 & 4.0 & 4.1 & 2.8 & 3.0 & 2.8 & 2.8 & 2.7 & 2.9 & $790 \mathrm{k}$ & $580 \mathrm{k}$ & $60 \mathrm{k}$ & $74 \mathrm{k}$ & $1.5 \mathrm{M}$ \\
\hline & Australia & 2.7 & 4.5 & 5.3 & 4.1 & 3.5 & 3.0 & 2.7 & 2.6 & 2.8 & 2.9 & $380 \mathrm{k}$ & $220 \mathrm{k}$ & $42 \mathrm{k}$ & $64 \mathrm{k}$ & $710 \mathrm{k}$ \\
\hline & Poland & 1.9 & 3.0 & 3.9 & 4.0 & 2.6 & 3.1 & 2.9 & 2.7 & 2.7 & 2.9 & $230 \mathrm{k}$ & $210 \mathrm{k}$ & $25 \mathrm{k}$ & $39 \mathrm{k}$ & $530 \mathrm{k}$ \\
\hline & Tanzania & 3.0 & 2.4 & 3.8 & 4.0 & 3.5 & 2.9 & 2.9 & 2.8 & 2.8 & 2.8 & $25 \mathrm{k}$ & $13 \mathrm{k}$ & $20 \mathrm{k}$ & $31 \mathrm{k}$ & $110 \mathrm{k}$ \\
\hline & France & 2.3 & 3.6 & 3.9 & 4.0 & 2.9 & 3.0 & 2.8 & 2.7 & 2.7 & 2.9 & $1.1 \mathrm{M}$ & $780 \mathrm{k}$ & $140 \mathrm{k}$ & $150 \mathrm{k}$ & $2.2 \mathrm{M}$ \\
\hline & Czech Republic & 2.0 & 3.2 & 3.7 & 4.0 & 2.6 & 3.0 & 2.8 & 2.7 & 2.7 & 2.9 & $150 \mathrm{k}$ & $89 \mathrm{k}$ & $7.4 \mathrm{k}$ & $15 \mathrm{k}$ & $270 \mathrm{k}$ \\
\hline & Mexico & 1.7 & 2.4 & 3.1 & 3.9 & 2.6 & 3.2 & 3.1 & 3.0 & 3.0 & 3.1 & $430 \mathrm{k}$ & $760 \mathrm{k}$ & $240 \mathrm{k}$ & $280 \mathrm{k}$ & $1.9 \mathrm{M}$ \\
\hline & Mongolia & 3.4 & 4.2 & 4.6 & 3.9 & 3.7 & 2.8 & 2.7 & 2.8 & 2.8 & 2.8 & $1.5 \mathrm{k}$ & $6.5 \mathrm{k}$ & 830 & $3.4 \mathrm{k}$ & $27 \mathrm{k}$ \\
\hline & Finland & 2.0 & 2.8 & 3.5 & 3.9 & 3.1 & 3.2 & 3.0 & 2.9 & 2.9 & 2.9 & $54 \mathrm{k}$ & $40 \mathrm{k}$ & $11 \mathrm{k}$ & $15 \mathrm{k}$ & $160 \mathrm{k}$ \\
\hline & Mauritius & 2.9 & & & 3.9 & 3.0 & 2.9 & & & 2.8 & 2.8 & $17 \mathrm{k}$ & & & $3 \mathrm{k}$ & $21 \mathrm{k}$ \\
\hline & Estonia & 1.5 & 2.4 & 4.1 & 3.9 & 2.6 & 3.2 & 3.0 & 2.8 & 2.9 & 3.0 & $12 \mathrm{k}$ & $9.6 \mathrm{k}$ & $1.2 \mathrm{k}$ & $1.5 \mathrm{k}$ & $33 \mathrm{k}$ \\
\hline & $\begin{array}{l}\text { Hong Kong SAR, } \\
\text { China }\end{array}$ & 1.1 & 2.1 & 1.5 & 3.9 & 1.4 & 3.3 & 3.2 & 3.4 & 3.1 & 3.3 & $7.5 \mathrm{k}$ & $3 \mathrm{k}$ & 530 & 130 & $11 \mathrm{k}$ \\
\hline & Uzbekistan & 3.2 & 3.1 & 3.9 & 3.9 & 3.5 & 2.9 & 2.9 & 2.8 & 2.7 & 2.8 & $78 \mathrm{k}$ & $65 \mathrm{k}$ & $13 \mathrm{k}$ & $18 \mathrm{k}$ & $210 \mathrm{k}$ \\
\hline & Cambodia & 2.3 & 2.8 & 3.2 & 3.9 & 3.3 & 3.1 & 2.9 & 2.9 & 2.9 & 2.9 & $2.5 \mathrm{k}$ & $11 \mathrm{k}$ & $4.4 \mathrm{k}$ & $12 \mathrm{k}$ & $41 \mathrm{k}$ \\
\hline & Tajikistan & 3.8 & 3.3 & 3.5 & 3.8 & 4.0 & 2.8 & 2.9 & 2.8 & 2.8 & 2.8 & $9.9 \mathrm{k}$ & $8.3 \mathrm{k}$ & $1.5 \mathrm{k}$ & $4.1 \mathrm{k}$ & $33 \mathrm{k}$ \\
\hline & $\begin{array}{l}\text { Dominican Repub- } \\
\text { lic }\end{array}$ & 1.7 & 3.1 & 2.8 & 3.7 & 2.7 & 3.2 & 3.0 & 3.0 & 2.9 & 3.0 & $35 \mathrm{k}$ & $43 \mathrm{k}$ & $20 \mathrm{k}$ & $12 \mathrm{k}$ & $110 \mathrm{k}$ \\
\hline & Malawi & 3.8 & 3.6 & 3.9 & 3.7 & 3.7 & 2.8 & 2.8 & 2.7 & 2.7 & 2.8 & $11 \mathrm{k}$ & $6.1 \mathrm{k}$ & $6.6 \mathrm{k}$ & $23 \mathrm{k}$ & $58 \mathrm{k}$ \\
\hline & Portugal & 2.8 & 3.2 & 3.8 & 3.7 & 3.1 & 3.0 & 2.9 & 2.8 & 2.8 & 2.9 & $170 \mathrm{k}$ & $140 \mathrm{k}$ & $45 \mathrm{k}$ & $33 \mathrm{k}$ & $390 \mathrm{k}$ \\
\hline & Moldova & 2.3 & 2.7 & 3.1 & 3.7 & 2.6 & 2.9 & 2.9 & 2.8 & 2.7 & 2.9 & $29 \mathrm{k}$ & $54 \mathrm{k}$ & $2.6 \mathrm{k}$ & $1.4 \mathrm{k}$ & $88 \mathrm{k}$ \\
\hline & Myanmar & 2.8 & 2.8 & 2.0 & 3.7 & 3.0 & 3.0 & 3.0 & 3.1 & 2.9 & 2.9 & $30 \mathrm{k}$ & $49 \mathrm{k}$ & $29 \mathrm{k}$ & $35 \mathrm{k}$ & $180 \mathrm{k}$ \\
\hline & Hungary & 1.6 & 2.8 & 3.5 & 3.6 & 2.3 & 3.1 & 2.9 & 2.8 & 2.7 & 2.9 & $120 \mathrm{k}$ & $86 \mathrm{k}$ & $8.8 \mathrm{k}$ & $11 \mathrm{k}$ & $230 \mathrm{k}$ \\
\hline & Sweden & 2.0 & 3.1 & 3.6 & 3.6 & 2.6 & 3.1 & 2.9 & 2.9 & 2.9 & 3.0 & $170 \mathrm{k}$ & $61 \mathrm{k}$ & $11 \mathrm{k}$ & $15 \mathrm{k}$ & $300 \mathrm{k}$ \\
\hline & Greece & 0.9 & 2.4 & 3.2 & 3.6 & 1.5 & 3.2 & 2.9 & 2.8 & 2.8 & 3.1 & $200 \mathrm{k}$ & $140 \mathrm{k}$ & $13 \mathrm{k}$ & $11 \mathrm{k}$ & $380 \mathrm{k}$ \\
\hline & Malta & 1.0 & 1.9 & 3.1 & 3.6 & 1.7 & 3.3 & 3.1 & 2.9 & 2.8 & 3.1 & $4.5 \mathrm{k}$ & $7.2 \mathrm{k}$ & 290 & 580 & $13 \mathrm{k}$ \\
\hline & Kenya & 4.5 & 4.1 & 4.9 & 3.6 & 4.1 & 2.8 & 2.8 & 2.7 & 2.8 & 2.7 & $3.2 \mathrm{k}$ & $12 \mathrm{k}$ & $7.5 \mathrm{k}$ & $20 \mathrm{k}$ & $58 \mathrm{k}$ \\
\hline
\end{tabular}




\begin{tabular}{|c|c|c|c|c|c|c|c|c|c|c|c|c|c|c|c|}
\hline & \multicolumn{5}{|c|}{ Sprawl (SNDi) } & \multicolumn{5}{|c|}{ Nodal degree } & \multicolumn{5}{|c|}{$\mathrm{N}($ nodes $)$} \\
\hline & $<1975$ & $75-89$ & 90-99 & $2000-13$ & Stock & $<1975$ & $75-89$ & $90-99$ & $2000-13$ & Stock & $<1975$ & $75-89$ & 90-99 & $2000-13$ & Stock \\
\hline Afghanistan & 5.6 & 3.8 & 5.3 & 3.6 & 4.8 & 2.6 & 2.8 & 2.6 & 3.0 & 2.7 & $6 \mathrm{k}$ & $13 \mathrm{k}$ & $2.1 \mathrm{k}$ & $8.3 \mathrm{k}$ & $97 \mathrm{k}$ \\
\hline $\begin{array}{l}\text { Central African Re- } \\
\text { public }\end{array}$ & 2.9 & 3.7 & 3.9 & 3.6 & 3.6 & 3.0 & 3.0 & 3.0 & 3.0 & 3.0 & $5.3 \mathrm{k}$ & $1.3 \mathrm{k}$ & $2.3 \mathrm{k}$ & $1.5 \mathrm{k}$ & $12 \mathrm{k}$ \\
\hline Canada & 2.2 & 3.2 & 3.7 & 3.5 & 2.7 & 3.1 & 3.0 & 2.9 & 3.0 & 3.0 & $370 \mathrm{k}$ & $190 \mathrm{k}$ & $49 \mathrm{k}$ & $66 \mathrm{k}$ & $720 \mathrm{k}$ \\
\hline Rwanda & 2.5 & 3.4 & 3.5 & 3.5 & 3.7 & 3.0 & 2.9 & 2.9 & 2.9 & 2.8 & 470 & $3.6 \mathrm{k}$ & $1.2 \mathrm{k}$ & $7.3 \mathrm{k}$ & $15 \mathrm{k}$ \\
\hline Belgium & 1.6 & 2.8 & 3.4 & 3.5 & 2.2 & 3.1 & 2.9 & 2.8 & 2.7 & 3.0 & $160 \mathrm{k}$ & $93 \mathrm{k}$ & $15 \mathrm{k}$ & $18 \mathrm{k}$ & $290 \mathrm{k}$ \\
\hline Latvia & 1.5 & 2.3 & 3.7 & 3.5 & 2.6 & 3.2 & 3.0 & 2.8 & 2.9 & 2.9 & $14 \mathrm{k}$ & $13 \mathrm{k}$ & $2.2 \mathrm{k}$ & $1.5 \mathrm{k}$ & $46 \mathrm{k}$ \\
\hline Kazakhstan & 2.9 & 2.5 & 3.2 & 3.5 & 3.0 & 3.0 & 3.1 & 3.0 & 3.0 & 3.0 & $33 \mathrm{k}$ & $64 \mathrm{k}$ & $9.4 \mathrm{k}$ & $15 \mathrm{k}$ & $150 \mathrm{k}$ \\
\hline Zambia & 2.4 & 2.9 & 3.3 & 3.5 & 3.3 & 3.0 & 3.0 & 2.9 & 2.9 & 2.9 & $27 \mathrm{k}$ & $9.7 \mathrm{k}$ & $4 \mathrm{k}$ & $15 \mathrm{k}$ & $73 \mathrm{k}$ \\
\hline $\begin{array}{l}\text { Congo, Dem. } \\
\text { Rep. }\end{array}$ & 3.0 & 3.2 & 3.3 & 3.5 & 3.6 & 3.1 & 3.1 & 3.0 & 2.9 & 2.9 & $86 \mathrm{k}$ & $55 \mathrm{k}$ & $36 \mathrm{k}$ & $63 \mathrm{k}$ & $290 \mathrm{k}$ \\
\hline Pakistan & 2.2 & 2.8 & 3.6 & 3.5 & 2.8 & 3.1 & 2.9 & 2.9 & 2.9 & 3.0 & $78 \mathrm{k}$ & $78 \mathrm{k}$ & $23 \mathrm{k}$ & $53 \mathrm{k}$ & $250 \mathrm{k}$ \\
\hline Nigeria & 2.5 & 3.4 & 4.2 & 3.4 & 3.5 & 2.9 & 2.8 & 2.7 & 2.8 & 2.8 & $160 \mathrm{k}$ & $260 \mathrm{k}$ & $110 \mathrm{k}$ & $430 \mathrm{k}$ & $1.3 \mathrm{M}$ \\
\hline Chile & 2.0 & 2.6 & 3.2 & 3.4 & 2.6 & 3.1 & 3.0 & 2.9 & 2.9 & 3.0 & $130 \mathrm{k}$ & $80 \mathrm{k}$ & $46 \mathrm{k}$ & $51 \mathrm{k}$ & $320 \mathrm{k}$ \\
\hline Oman & 3.7 & 2.8 & 3.5 & 3.4 & 3.4 & 2.7 & 3.0 & 2.8 & 2.9 & 2.8 & $7.7 \mathrm{k}$ & $11 \mathrm{k}$ & $8.4 \mathrm{k}$ & $7.6 \mathrm{k}$ & $53 \mathrm{k}$ \\
\hline Colombia & 1.6 & -0.1 & 2.8 & 3.4 & 1.8 & 3.2 & 3.3 & 3.0 & 2.9 & 3.2 & $290 \mathrm{k}$ & 120 & $22 \mathrm{k}$ & $23 \mathrm{k}$ & $350 \mathrm{k}$ \\
\hline Zimbabwe & 2.5 & 3.0 & 3.4 & 3.4 & 3.1 & 3.0 & 2.9 & 2.9 & 2.9 & 2.9 & $8 \mathrm{k}$ & $25 \mathrm{k}$ & $14 \mathrm{k}$ & $9.6 \mathrm{k}$ & $66 \mathrm{k}$ \\
\hline $\begin{array}{l}\text { Egypt, Arab } \\
\text { Rep. }\end{array}$ & 3.5 & 3.1 & 3.4 & 3.3 & 3.4 & 2.8 & 2.9 & 2.8 & 2.9 & 2.9 & $240 \mathrm{k}$ & $110 \mathrm{k}$ & $31 \mathrm{k}$ & $54 \mathrm{k}$ & $460 \mathrm{k}$ \\
\hline Togo & 2.1 & 2.0 & 2.3 & 3.3 & 2.6 & 3.0 & 3.0 & 3.0 & 2.8 & 2.9 & $14 \mathrm{k}$ & $12 \mathrm{k}$ & $8.1 \mathrm{k}$ & $11 \mathrm{k}$ & $53 \mathrm{k}$ \\
\hline Cuba & 0.9 & 2.2 & 2.7 & 3.3 & 1.4 & 3.3 & 3.0 & 2.9 & 2.8 & 3.1 & $60 \mathrm{k}$ & $37 \mathrm{k}$ & $3 \mathrm{k}$ & $2.3 \mathrm{k}$ & $100 \mathrm{k}$ \\
\hline Luxembourg & 2.0 & 2.9 & 3.2 & 3.2 & 2.4 & 3.1 & 2.9 & 2.9 & 2.8 & 3.0 & $8.3 \mathrm{k}$ & $5.3 \mathrm{k}$ & $1.3 \mathrm{k}$ & 910 & $16 \mathrm{k}$ \\
\hline Germany & 1.9 & 3.0 & 3.2 & 3.2 & 2.3 & 3.1 & 2.9 & 2.8 & 2.8 & 3.0 & $1.4 \mathrm{M}$ & $640 \mathrm{k}$ & $100 \mathrm{k}$ & $110 \mathrm{k}$ & $2.3 \mathrm{M}$ \\
\hline Benin & 1.3 & 2.1 & 2.3 & 3.2 & 2.5 & 3.1 & 3.0 & 3.0 & 2.8 & 2.9 & $12 \mathrm{k}$ & $18 \mathrm{k}$ & $15 \mathrm{k}$ & $17 \mathrm{k}$ & $68 \mathrm{k}$ \\
\hline Cabo Verde & 2.6 & & & 3.2 & 2.8 & 3.1 & & & 3.0 & 3.1 & $3.3 \mathrm{k}$ & & & 480 & $5.7 \mathrm{k}$ \\
\hline Lesotho & 3.5 & 2.8 & 2.7 & 3.1 & 3.4 & 2.8 & 2.9 & 2.9 & 2.9 & 2.8 & 800 & $8.4 \mathrm{k}$ & $9.1 \mathrm{k}$ & $12 \mathrm{k}$ & $43 \mathrm{k}$ \\
\hline Yemen, Rep. & 3.3 & 2.2 & 3.4 & 3.1 & 3.3 & 3.0 & 3.1 & 3.0 & 3.0 & 3.0 & $4 \mathrm{k}$ & $13 \mathrm{k}$ & $3 \mathrm{k}$ & $19 \mathrm{k}$ & $48 \mathrm{k}$ \\
\hline Qatar & 2.4 & 3.0 & 3.2 & 3.1 & 2.9 & 3.1 & 3.0 & 3.0 & 3.0 & 3.0 & $7.5 \mathrm{k}$ & $17 \mathrm{k}$ & $1.6 \mathrm{k}$ & $4.2 \mathrm{k}$ & $33 \mathrm{k}$ \\
\hline Burundi & 2.4 & 3.2 & 3.7 & 3.1 & 3.3 & 3.2 & 2.9 & 2.9 & 2.9 & 2.9 & $1.5 \mathrm{k}$ & $2.7 \mathrm{k}$ & $2.7 \mathrm{k}$ & $6.9 \mathrm{k}$ & $20 \mathrm{k}$ \\
\hline Kyrgyz Republic & 2.9 & 3.2 & 3.0 & 3.1 & 3.2 & 2.9 & 2.9 & 2.9 & 2.9 & 2.9 & $11 \mathrm{k}$ & $17 \mathrm{k}$ & $5.3 \mathrm{k}$ & $13 \mathrm{k}$ & $52 \mathrm{k}$ \\
\hline Namibia & 2.0 & 2.2 & 3.4 & 3.1 & 2.8 & 3.1 & 3.1 & 2.9 & 3.0 & 3.0 & $2.3 \mathrm{k}$ & $5 \mathrm{k}$ & $4 \mathrm{k}$ & $3.9 \mathrm{k}$ & $18 \mathrm{k}$ \\
\hline $\begin{array}{l}\text { Iran, } \quad \text { Islamic } \\
\text { Rep. }\end{array}$ & 3.5 & 2.7 & 3.0 & 2.9 & 3.0 & 2.7 & 2.9 & 2.9 & 2.9 & 2.9 & $210 \mathrm{k}$ & $370 \mathrm{k}$ & $79 \mathrm{k}$ & $200 \mathrm{k}$ & $950 \mathrm{k}$ \\
\hline $\begin{array}{l}\text { Syrian Arab Re- } \\
\text { public }\end{array}$ & 1.3 & 1.8 & 2.3 & 2.9 & 1.7 & 3.1 & 3.1 & 2.9 & 2.9 & 3.0 & $81 \mathrm{k}$ & $70 \mathrm{k}$ & $12 \mathrm{k}$ & $17 \mathrm{k}$ & $190 \mathrm{k}$ \\
\hline Brazil & 1.8 & 2.2 & 2.3 & 2.9 & 2.1 & 3.2 & 3.1 & 3.1 & 3.0 & 3.1 & $1.6 \mathrm{M}$ & $820 \mathrm{k}$ & $430 \mathrm{k}$ & $280 \mathrm{k}$ & $3.4 \mathrm{M}$ \\
\hline
\end{tabular}




\begin{tabular}{|c|c|c|c|c|c|c|c|c|c|c|c|c|c|c|c|}
\hline & \multicolumn{5}{|c|}{ Sprawl (SNDi) } & \multicolumn{5}{|c|}{ Nodal degree } & \multicolumn{5}{|c|}{$\mathrm{N}($ nodes $)$} \\
\hline & $<1975$ & $75-89$ & $90-99$ & $2000-13$ & Stock & $<1975$ & $75-89$ & $90-99$ & 2000-13 & Stock & $<1975$ & $75-89$ & $90-99$ & $2000-13$ & Stock \\
\hline Saudi Arabia & 2.0 & 2.3 & 2.8 & 2.8 & 2.9 & 3.2 & 3.1 & 3.1 & 3.1 & 3.1 & $58 \mathrm{k}$ & $160 \mathrm{k}$ & $40 \mathrm{k}$ & $66 \mathrm{k}$ & $420 \mathrm{k}$ \\
\hline China & 2.9 & 3.0 & 2.7 & 2.8 & 3.1 & 3.0 & 3.0 & 3.1 & 3.1 & 3.0 & $340 \mathrm{k}$ & $520 \mathrm{k}$ & $220 \mathrm{k}$ & $460 \mathrm{k}$ & $1.9 \mathrm{M}$ \\
\hline Iceland & 1.9 & & 3.3 & 2.8 & 2.5 & 3.1 & & 2.9 & 3.0 & 3.0 & $5.6 \mathrm{k}$ & & 960 & $2.4 \mathrm{k}$ & $12 \mathrm{k}$ \\
\hline $\begin{array}{l}\text { United Arab Emi- } \\
\text { rates }\end{array}$ & 1.7 & 1.2 & 2.2 & 2.8 & 1.9 & 3.2 & 3.2 & 3.1 & 3.1 & 3.1 & $40 \mathrm{k}$ & $11 \mathrm{k}$ & $5.4 \mathrm{k}$ & $9.3 \mathrm{k}$ & $90 \mathrm{k}$ \\
\hline Algeria & 2.5 & 2.1 & 2.1 & 2.8 & 2.3 & 3.0 & 3.1 & 3.1 & 3.0 & 3.0 & $35 \mathrm{k}$ & $240 \mathrm{k}$ & $63 \mathrm{k}$ & $57 \mathrm{k}$ & $410 \mathrm{k}$ \\
\hline Tunisia & 1.7 & 2.0 & 1.9 & 2.7 & 1.9 & 3.1 & 3.0 & 3.1 & 3.0 & 3.0 & $37 \mathrm{k}$ & $83 \mathrm{k}$ & $21 \mathrm{k}$ & $9.5 \mathrm{k}$ & $150 \mathrm{k}$ \\
\hline Ethiopia & 2.8 & 2.5 & 2.4 & 2.7 & 2.7 & 3.0 & 3.0 & 3.1 & 3.1 & 3.0 & $6.7 \mathrm{k}$ & $23 \mathrm{k}$ & $21 \mathrm{k}$ & $99 \mathrm{k}$ & $190 \mathrm{k}$ \\
\hline Angola & 2.8 & 3.4 & 3.4 & 2.6 & 2.9 & 3.0 & 2.9 & 3.0 & 3.1 & 3.0 & $27 \mathrm{k}$ & $24 \mathrm{k}$ & $11 \mathrm{k}$ & $59 \mathrm{k}$ & $150 \mathrm{k}$ \\
\hline Turkey & 1.6 & 1.5 & 2.1 & 2.6 & 1.9 & 3.1 & 3.1 & 3.1 & 3.0 & 3.1 & $260 \mathrm{k}$ & $510 \mathrm{k}$ & $150 \mathrm{k}$ & $100 \mathrm{k}$ & $1.1 \mathrm{M}$ \\
\hline Ecuador & 2.0 & & 2.5 & 2.6 & 2.2 & 3.1 & & 3.1 & 3.1 & 3.1 & $150 \mathrm{k}$ & & $12 \mathrm{k}$ & $17 \mathrm{k}$ & $210 \mathrm{k}$ \\
\hline Belarus & 1.8 & 2.2 & 2.7 & 2.6 & 2.8 & 3.2 & 3.0 & 3.0 & 3.0 & 2.9 & $39 \mathrm{k}$ & $34 \mathrm{k}$ & $8.6 \mathrm{k}$ & $6.7 \mathrm{k}$ & $160 \mathrm{k}$ \\
\hline Spain & 1.2 & 2.1 & 2.6 & 2.6 & 1.8 & 3.2 & 3.0 & 3.0 & 3.0 & 3.1 & $580 \mathrm{k}$ & $470 \mathrm{k}$ & $130 \mathrm{k}$ & $110 \mathrm{k}$ & $1.4 \mathrm{M}$ \\
\hline Kuwait & 2.7 & 4.1 & 3.1 & 2.5 & 3.0 & 3.2 & 3.2 & 3.2 & 3.2 & 3.2 & $20 \mathrm{k}$ & $10 \mathrm{k}$ & $2 \mathrm{k}$ & $2.5 \mathrm{k}$ & $37 \mathrm{k}$ \\
\hline Netherlands & 1.5 & 2.2 & 2.2 & 2.5 & 1.9 & 3.2 & 3.1 & 3.1 & 3.0 & 3.1 & $260 \mathrm{k}$ & $140 \mathrm{k}$ & $52 \mathrm{k}$ & $54 \mathrm{k}$ & $500 \mathrm{k}$ \\
\hline Turkmenistan & 1.9 & 2.3 & 2.1 & 2.4 & 2.4 & 3.2 & 3.1 & 3.1 & 3.1 & 3.1 & $5 \mathrm{k}$ & $7.1 \mathrm{k}$ & $2.7 \mathrm{k}$ & $3.6 \mathrm{k}$ & $26 \mathrm{k}$ \\
\hline Korea, Rep. & 0.9 & 1.4 & 2.0 & 2.4 & 1.4 & 3.2 & 3.2 & 3.1 & 3.1 & 3.2 & $160 \mathrm{k}$ & $120 \mathrm{k}$ & $37 \mathrm{k}$ & $37 \mathrm{k}$ & $370 \mathrm{k}$ \\
\hline Gambia, The & 0.5 & 1.5 & 1.6 & 2.3 & 1.4 & 3.2 & 3.1 & 3.1 & 2.9 & 3.1 & $5.7 \mathrm{k}$ & $5.1 \mathrm{k}$ & $4.8 \mathrm{k}$ & $1.6 \mathrm{k}$ & $19 \mathrm{k}$ \\
\hline Iraq & 2.1 & 1.8 & 2.0 & 2.2 & 2.0 & 3.1 & 3.1 & 3.0 & 3.0 & 3.1 & $28 \mathrm{k}$ & $150 \mathrm{k}$ & $21 \mathrm{k}$ & $110 \mathrm{k}$ & $320 \mathrm{k}$ \\
\hline Botswana & 1.8 & 2.3 & 2.7 & 2.2 & 2.2 & 3.0 & 3.0 & 2.9 & 3.0 & 3.0 & $4.3 \mathrm{k}$ & $20 \mathrm{k}$ & $14 \mathrm{k}$ & $11 \mathrm{k}$ & $71 \mathrm{k}$ \\
\hline Paraguay & 1.1 & 1.5 & 1.6 & 2.1 & 1.4 & 3.3 & 3.2 & 3.2 & 3.2 & 3.2 & $34 \mathrm{k}$ & $21 \mathrm{k}$ & $9.8 \mathrm{k}$ & $7.7 \mathrm{k}$ & $89 \mathrm{k}$ \\
\hline Morocco & 1.5 & 1.9 & 1.9 & 2.0 & 1.9 & 3.2 & 3.1 & 3.1 & 3.1 & 3.1 & $81 \mathrm{k}$ & $86 \mathrm{k}$ & $29 \mathrm{k}$ & $59 \mathrm{k}$ & $280 \mathrm{k}$ \\
\hline Uruguay & -0.3 & 0.5 & 1.7 & 2.0 & 0.4 & 3.5 & 3.3 & 3.1 & 3.0 & 3.4 & $24 \mathrm{k}$ & $29 \mathrm{k}$ & $6.9 \mathrm{k}$ & $2.9 \mathrm{k}$ & $66 \mathrm{k}$ \\
\hline Mali & 0.7 & 1.0 & 1.5 & 1.9 & 1.5 & 3.3 & 3.2 & 3.2 & 3.1 & 3.2 & $7.8 \mathrm{k}$ & $33 \mathrm{k}$ & $8.8 \mathrm{k}$ & $28 \mathrm{k}$ & $89 \mathrm{k}$ \\
\hline Niger & 0.2 & 0.6 & 1.3 & 1.8 & 1.4 & 3.3 & 3.3 & 3.2 & 3.2 & 3.2 & $4.2 \mathrm{k}$ & $8.1 \mathrm{k}$ & $4.5 \mathrm{k}$ & $17 \mathrm{k}$ & $46 \mathrm{k}$ \\
\hline Sudan & 0.6 & 1.1 & 1.6 & 1.8 & 1.6 & 3.3 & 3.4 & 3.3 & 3.3 & 3.3 & $64 \mathrm{k}$ & $52 \mathrm{k}$ & $12 \mathrm{k}$ & $92 \mathrm{k}$ & $320 \mathrm{k}$ \\
\hline Japan & 1.1 & 1.5 & 2.2 & 1.8 & 1.3 & 3.2 & 3.1 & 3.1 & 3.1 & 3.1 & $2.8 \mathrm{M}$ & $990 \mathrm{k}$ & $130 \mathrm{k}$ & $110 \mathrm{k}$ & $4 \mathrm{M}$ \\
\hline Taiwan, China & 1.1 & 2.1 & 2.0 & 1.8 & 1.3 & 3.2 & 3.1 & 3.2 & 3.2 & 3.2 & $130 \mathrm{k}$ & $12 \mathrm{k}$ & $7.9 \mathrm{k}$ & $7.5 \mathrm{k}$ & $160 \mathrm{k}$ \\
\hline Mozambique & 2.1 & 1.2 & 1.7 & 1.7 & 1.8 & 3.1 & 3.1 & 3.1 & 3.0 & 3.0 & $16 \mathrm{k}$ & $33 \mathrm{k}$ & $16 \mathrm{k}$ & $38 \mathrm{k}$ & $130 \mathrm{k}$ \\
\hline Senegal & 0.9 & 1.2 & 1.3 & 1.6 & 1.5 & 3.3 & 3.3 & 3.2 & 3.1 & 3.2 & $30 \mathrm{k}$ & $47 \mathrm{k}$ & $19 \mathrm{k}$ & $31 \mathrm{k}$ & $150 \mathrm{k}$ \\
\hline South Sudan & 0.9 & 0.6 & 2.4 & 1.6 & 1.9 & 3.4 & 3.4 & 3.4 & 3.3 & 3.3 & $2 \mathrm{k}$ & $1.2 \mathrm{k}$ & $1.1 \mathrm{k}$ & $11 \mathrm{k}$ & $21 \mathrm{k}$ \\
\hline Eritrea & 3.6 & 2.6 & 3.0 & 1.6 & 2.6 & 3.0 & 3.1 & 3.1 & 3.2 & 3.1 & $2.2 \mathrm{k}$ & $1.7 \mathrm{k}$ & 630 & $2.4 \mathrm{k}$ & $18 \mathrm{k}$ \\
\hline Peru & 1.5 & 0.8 & 1.5 & 1.5 & 1.5 & 3.2 & 3.3 & 3.2 & 3.2 & 3.2 & $190 \mathrm{k}$ & $11 \mathrm{k}$ & $9.1 \mathrm{k}$ & $23 \mathrm{k}$ & $280 \mathrm{k}$ \\
\hline Argentina & 0.2 & 0.5 & 1.1 & 1.5 & 0.6 & 3.5 & 3.4 & 3.3 & 3.3 & 3.4 & $300 \mathrm{k}$ & $310 \mathrm{k}$ & $84 \mathrm{k}$ & $69 \mathrm{k}$ & $820 \mathrm{k}$ \\
\hline Burkina Faso & 0.6 & 1.3 & 1.4 & 1.5 & 1.5 & 3.3 & 3.2 & 3.2 & 3.1 & 3.1 & $16 \mathrm{k}$ & $10 \mathrm{k}$ & $12 \mathrm{k}$ & $28 \mathrm{k}$ & $74 \mathrm{k}$ \\
\hline Belize & 1.4 & 2.1 & 2.8 & 1.5 & 2.2 & 3.1 & 3.1 & 3.0 & 3.1 & 3.0 & $2.7 \mathrm{k}$ & $1.6 \mathrm{k}$ & $2.1 \mathrm{k}$ & 620 & $9 \mathrm{k}$ \\
\hline
\end{tabular}




\begin{tabular}{|c|c|c|c|c|c|c|c|c|c|c|c|c|c|c|c|}
\hline & \multicolumn{5}{|c|}{ Sprawl (SNDi) } & \multicolumn{5}{|c|}{ Nodal degree } & \multicolumn{5}{|c|}{$\mathrm{N}$ (nodes) } \\
\hline & $<1975$ & $75-89$ & $90-99$ & $2000-13$ & Stock & $<1975$ & $75-89$ & $90-99$ & $2000-13$ & Stock & $<1975$ & $75-89$ & $90-99$ & $2000-13$ & Stock \\
\hline Bolivia & 1.3 & 1.1 & 1.0 & 1.2 & 1.5 & 3.3 & 3.3 & 3.3 & 3.3 & 3.2 & $42 \mathrm{k}$ & $34 \mathrm{k}$ & $26 \mathrm{k}$ & $36 \mathrm{k}$ & $170 \mathrm{k}$ \\
\hline Singapore & 1.9 & & 1.3 & 1.1 & 1.9 & 3.3 & & 3.4 & 3.5 & 3.3 & $17 \mathrm{k}$ & & 380 & 170 & $18 \mathrm{k}$ \\
\hline Chad & 0.0 & 1.2 & 1.0 & 1.1 & 1.2 & 3.4 & 3.4 & 3.3 & 3.3 & 3.3 & $5.6 \mathrm{k}$ & $3.1 \mathrm{k}$ & $4.9 \mathrm{k}$ & $12 \mathrm{k}$ & $34 \mathrm{k}$ \\
\hline Somalia & 0.9 & 0.9 & 1.6 & 1.0 & 1.1 & 3.4 & 3.3 & 3.3 & 3.3 & 3.3 & $16 \mathrm{k}$ & $16 \mathrm{k}$ & $4.7 \mathrm{k}$ & $19 \mathrm{k}$ & $60 \mathrm{k}$ \\
\hline Mauritania & 0.1 & 0.2 & 0.5 & 0.5 & 0.6 & 3.4 & 3.3 & 3.3 & 3.3 & 3.3 & $5.8 \mathrm{k}$ & $3.5 \mathrm{k}$ & $2.1 \mathrm{k}$ & $4.1 \mathrm{k}$ & $26 \mathrm{k}$ \\
\hline Maldives & -0.6 & & & -0.3 & 0.7 & 3.3 & & & 3.3 & 3.0 & 440 & & & 280 & $7 \mathrm{k}$ \\
\hline
\end{tabular}


F.6 Cities ranked by urban street-network sprawl (SNDi) of recent road development 
Table S2: Cities listed in order of their recent urban streetnetwork sprawl (SNDi).

\begin{tabular}{|c|c|c|c|c|c|c|c|c|c|c|c|c|}
\hline & \multicolumn{4}{|c|}{ Sprawl (SNDi) } & \multicolumn{4}{|c|}{ Nodal degree } & \multicolumn{4}{|c|}{$\mathrm{N}($ nodes $)$} \\
\hline & $<1990$ & 90-99 & '00-13 & Stock & $<1990$ & $90-99$ & '00-13 & Stock & $<1990$ & $90-99$ & '00-13 & Stock \\
\hline Suva, FiJI & 3.5 & 8.4 & 10.4 & 8.2 & 2.9 & 2.3 & 2.1 & 2.4 & 150 & $1.4 \mathrm{k}$ & 150 & $1.7 \mathrm{k}$ \\
\hline Caracas, Venezuela & 4.9 & 10.4 & 10.1 & 5.3 & 2.8 & 2.3 & 2.3 & 2.8 & $11 \mathrm{k}$ & 770 & 540 & $12 \mathrm{k}$ \\
\hline Bangkok, Thailand & 6.8 & 7.6 & 8.1 & 7.3 & 2.5 & 2.5 & 2.4 & 2.5 & $74 \mathrm{k}$ & $30 \mathrm{k}$ & $46 \mathrm{k}$ & $150 \mathrm{k}$ \\
\hline Guatemala City, Guatemala & 3.8 & 5.6 & 7.5 & 4.5 & 3.0 & 2.8 & 2.5 & 2.9 & $22 \mathrm{k}$ & $7.3 \mathrm{k}$ & $4.7 \mathrm{k}$ & $34 \mathrm{k}$ \\
\hline Cebu City, Philippines & 6.1 & 6.9 & 7.3 & 6.6 & 2.6 & 2.5 & 2.6 & 2.6 & $5.7 \mathrm{k}$ & $2.3 \mathrm{k}$ & $4.5 \mathrm{k}$ & $12 \mathrm{k}$ \\
\hline Gorgan, Iran & 3.6 & 5.8 & 6.7 & 3.9 & 2.7 & 2.5 & 2.4 & 2.7 & $3.3 \mathrm{k}$ & 470 & 240 & $4 \mathrm{k}$ \\
\hline Los Angeles, United States & 3.6 & 6.2 & 6.3 & 3.9 & 2.9 & 2.6 & 2.6 & 2.9 & $250 \mathrm{k}$ & $26 \mathrm{k}$ & $9.7 \mathrm{k}$ & $290 \mathrm{k}$ \\
\hline Raleigh, United States & 4.8 & 5.4 & 6.3 & 5.6 & 2.8 & 2.7 & 2.5 & 2.6 & $11 \mathrm{k}$ & $21 \mathrm{k}$ & $19 \mathrm{k}$ & $51 \mathrm{k}$ \\
\hline Palembang, Indonesia & 4.7 & 5.6 & 6.3 & 5.2 & 2.6 & 2.5 & 2.5 & 2.6 & $15 \mathrm{k}$ & $19 \mathrm{k}$ & $3.9 \mathrm{k}$ & $39 \mathrm{k}$ \\
\hline New York, United States & 2.9 & 5.2 & 6.3 & 3.1 & 3.0 & 2.7 & 2.5 & 2.9 & $320 \mathrm{k}$ & $42 \mathrm{k}$ & $3.5 \mathrm{k}$ & $360 \mathrm{k}$ \\
\hline San Salvador, El Salvador & 4.4 & 7.1 & 6.1 & 5.0 & 2.8 & 2.5 & 2.6 & 2.7 & $11 \mathrm{k}$ & $1.7 \mathrm{k}$ & $4.7 \mathrm{k}$ & $17 \mathrm{k}$ \\
\hline Belgrade, Serbia & 2.9 & 6.6 & 6.0 & 4.2 & 3.0 & 2.3 & 2.4 & 2.7 & $9.1 \mathrm{k}$ & $2.2 \mathrm{k}$ & $4 \mathrm{k}$ & $15 \mathrm{k}$ \\
\hline Tijuana, Mexico & 4.3 & 3.6 & 6.0 & 4.4 & 2.9 & 3.0 & 2.7 & 2.9 & $15 \mathrm{k}$ & $9.2 \mathrm{k}$ & $8.5 \mathrm{k}$ & $33 \mathrm{k}$ \\
\hline Florianopolis, BrazIL & 2.9 & 5.9 & 5.9 & 4.1 & 2.9 & 2.5 & 2.6 & 2.8 & $7.2 \mathrm{k}$ & $2.5 \mathrm{k}$ & $3.2 \mathrm{k}$ & $13 \mathrm{k}$ \\
\hline Pune, India & 3.4 & 5.0 & 5.9 & 4.9 & 2.8 & 2.6 & 2.5 & 2.7 & $6.3 \mathrm{k}$ & $15 \mathrm{k}$ & $10 \mathrm{k}$ & $31 \mathrm{k}$ \\
\hline Sao Paulo, Brazil & 2.1 & 4.9 & 5.8 & 2.5 & 3.1 & 2.8 & 2.6 & 3.0 & $150 \mathrm{k}$ & $23 \mathrm{k}$ & $5.5 \mathrm{k}$ & $180 \mathrm{k}$ \\
\hline Medan, Indonesia & 4.0 & 5.2 & 5.8 & 4.9 & 2.7 & 2.5 & 2.5 & 2.6 & $20 \mathrm{k}$ & $29 \mathrm{k}$ & $16 \mathrm{k}$ & $64 \mathrm{k}$ \\
\hline Gainesville, United States & 3.0 & 6.4 & 5.6 & 3.8 & 3.1 & 2.7 & 2.8 & 3.0 & $3.9 \mathrm{k}$ & 800 & $1.2 \mathrm{k}$ & $5.8 \mathrm{k}$ \\
\hline Johannesburg, South Africa & 2.9 & 4.1 & 5.5 & 3.8 & 3.0 & 2.9 & 2.8 & 2.9 & $63 \mathrm{k}$ & $16 \mathrm{k}$ & $30 \mathrm{k}$ & $110 \mathrm{k}$ \\
\hline Dhaka, Bangladesh & 3.3 & 4.9 & 5.5 & 4.0 & 2.9 & 2.7 & 2.6 & 2.8 & $14 \mathrm{k}$ & $5.5 \mathrm{k}$ & $6.6 \mathrm{k}$ & $26 \mathrm{k}$ \\
\hline Kolkata, India & 3.2 & 4.6 & 5.4 & 3.9 & 2.9 & 2.7 & 2.6 & 2.8 & $20 \mathrm{k}$ & $10 \mathrm{k}$ & $6.4 \mathrm{k}$ & $36 \mathrm{k}$ \\
\hline Pematangsiantar, Indonesia & 3.2 & 4.6 & 5.4 & 3.7 & 2.9 & 2.8 & 2.6 & 2.9 & $1.5 \mathrm{k}$ & 300 & 280 & $2.1 \mathrm{k}$ \\
\hline Ulaanbaatar, Mongolia & 4.1 & 4.8 & 5.3 & 4.5 & 2.8 & 2.6 & 2.6 & 2.7 & $5.9 \mathrm{k}$ & $1.4 \mathrm{k}$ & $3.1 \mathrm{k}$ & $10 \mathrm{k}$ \\
\hline Kampala, UGANDA & 4.9 & 5.6 & 5.3 & 5.1 & 2.6 & 2.5 & 2.6 & 2.6 & $8.4 \mathrm{k}$ & $3.8 \mathrm{k}$ & $3.2 \mathrm{k}$ & $15 \mathrm{k}$ \\
\hline Houston, United States & 2.9 & 5.1 & 5.3 & 3.9 & 3.1 & 2.8 & 2.8 & 2.9 & $88 \mathrm{k}$ & $31 \mathrm{k}$ & $45 \mathrm{k}$ & $160 \mathrm{k}$ \\
\hline Philadelphia, United States & 2.3 & 4.9 & 5.2 & 2.8 & 3.1 & 2.8 & 2.7 & 3.0 & $120 \mathrm{k}$ & $25 \mathrm{k}$ & $15 \mathrm{k}$ & $160 \mathrm{k}$ \\
\hline Victoria, CANADA & 2.9 & 4.6 & 5.2 & 3.3 & 2.9 & 2.7 & 2.8 & 2.9 & $6.6 \mathrm{k}$ & $1.8 \mathrm{k}$ & 450 & $8.8 \mathrm{k}$ \\
\hline Ho Chi Minh City, Viet Nam & 1.8 & 4.2 & 5.2 & 4.6 & 3.2 & 2.8 & 2.6 & 2.7 & $6.1 \mathrm{k}$ & $13 \mathrm{k}$ & $45 \mathrm{k}$ & $64 \mathrm{k}$ \\
\hline Manila, Philippines & 3.9 & 5.1 & 5.1 & 4.4 & 3.0 & 2.9 & 2.9 & 2.9 & $62 \mathrm{k}$ & $26 \mathrm{k}$ & $29 \mathrm{k}$ & $120 \mathrm{k}$ \\
\hline Sheffield, United Kingdom & 3.4 & 5.1 & 5.1 & 3.5 & 2.8 & 2.5 & 2.5 & 2.7 & $29 \mathrm{k}$ & $2.5 \mathrm{k}$ & 810 & $32 \mathrm{k}$ \\
\hline Rawang, Malaysia & 3.5 & 4.7 & 5.0 & 4.7 & 3.0 & 3.0 & 2.9 & 2.9 & 540 & 820 & $3.8 \mathrm{k}$ & $5.1 \mathrm{k}$ \\
\hline Pokhara, Nepal & 3.2 & 4.5 & 5.0 & 3.6 & 2.7 & 2.6 & 2.5 & 2.7 & $1.8 \mathrm{k}$ & 280 & 470 & $2.6 \mathrm{k}$ \\
\hline Baku, Azerbaijan & 4.1 & 5.2 & 5.0 & 4.6 & 2.8 & 2.5 & 2.6 & 2.7 & $11 \mathrm{k}$ & $7.4 \mathrm{k}$ & $5.1 \mathrm{k}$ & $23 \mathrm{k}$ \\
\hline
\end{tabular}




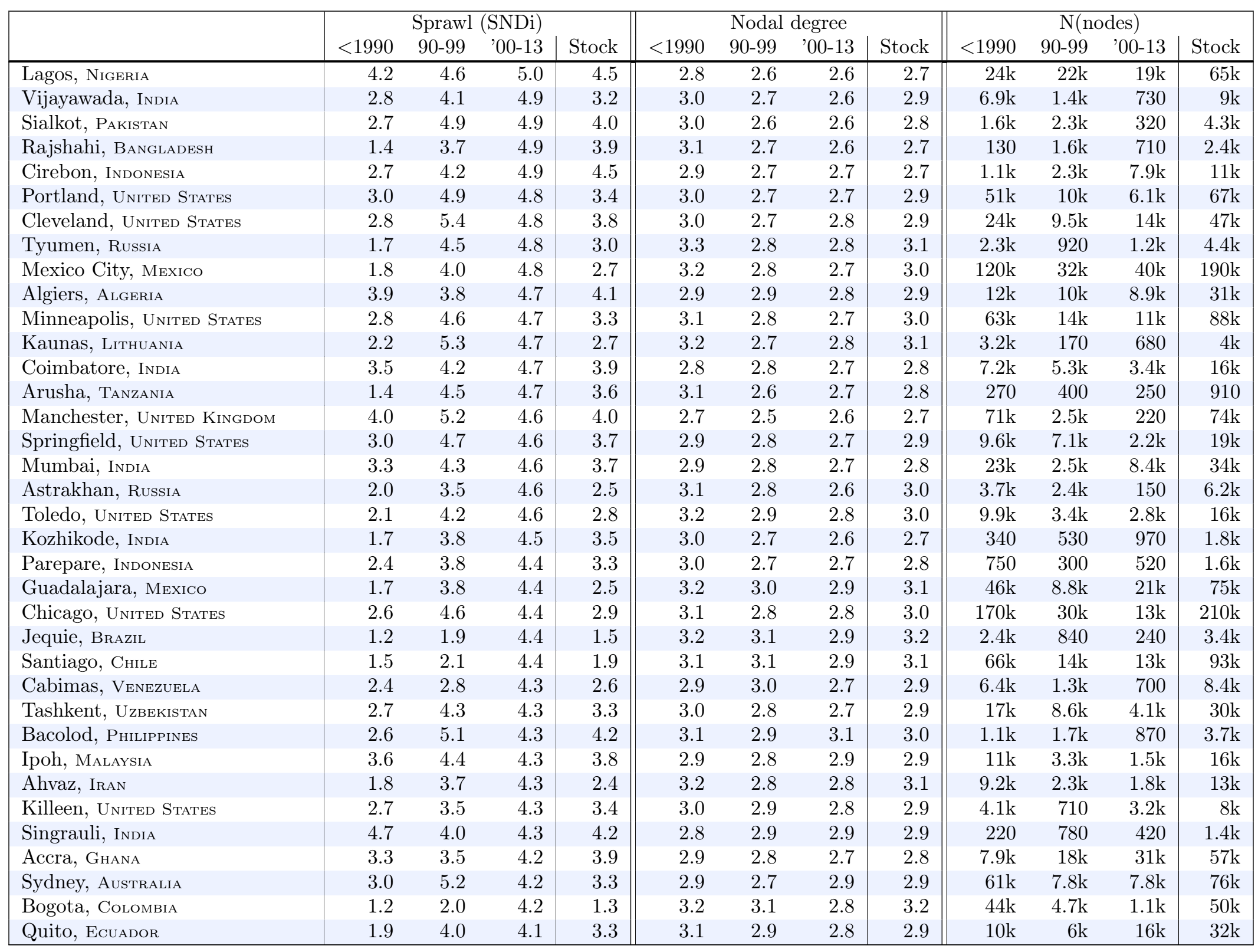




\begin{tabular}{|c|c|c|c|c|c|c|c|c|c|c|c|c|}
\hline & \multicolumn{4}{|c|}{ Sprawl (SNDi) } & \multicolumn{4}{|c|}{ Nodal degree } & \multicolumn{4}{|c|}{$\mathrm{N}$ (nodes) } \\
\hline & $<1990$ & $90-99$ & '00-13 & Stock & $<1990$ & $90-99$ & '00-13 & Stock & $<1990$ & $90-99$ & '00-13 & Stock \\
\hline Moscow, Russia & 1.3 & 3.3 & 4.1 & 2.2 & 3.4 & 3.0 & 2.9 & 3.2 & $30 \mathrm{k}$ & $11 \mathrm{k}$ & $13 \mathrm{k}$ & $54 \mathrm{k}$ \\
\hline Ibadan, Nigeria & 4.1 & 3.7 & 4.1 & 4.0 & 2.7 & 2.8 & 2.7 & 2.7 & $20 \mathrm{k}$ & $12 \mathrm{k}$ & $16 \mathrm{k}$ & $47 \mathrm{k}$ \\
\hline Belo Horizonte, BraziL & 1.5 & 3.7 & 4.1 & 1.8 & 3.2 & 2.9 & 2.9 & 3.2 & $42 \mathrm{k}$ & $4.7 \mathrm{k}$ & $2.8 \mathrm{k}$ & $50 \mathrm{k}$ \\
\hline London, United Kingdom & 3.3 & 4.3 & 4.1 & 3.4 & 2.8 & 2.7 & 2.7 & 2.8 & $150 \mathrm{k}$ & $25 \mathrm{k}$ & $2.8 \mathrm{k}$ & $180 \mathrm{k}$ \\
\hline Saidpur, Bangladesh & 2.7 & & 4.0 & 3.2 & 2.8 & & 2.6 & 2.8 & 270 & 19 & 130 & 420 \\
\hline Istanbul, Turkey & 1.0 & 1.6 & 4.0 & 1.5 & 3.2 & 3.2 & 2.8 & 3.2 & $76 \mathrm{k}$ & $48 \mathrm{k}$ & $21 \mathrm{k}$ & $140 \mathrm{k}$ \\
\hline Warsaw, Poland & 1.5 & 2.5 & 4.0 & 2.2 & 3.3 & 3.0 & 2.7 & 3.1 & $17 \mathrm{k}$ & $6.9 \mathrm{k}$ & $5.3 \mathrm{k}$ & $29 \mathrm{k}$ \\
\hline Curitiba, BrazIL & 1.8 & 3.0 & 4.0 & 2.4 & 3.2 & 3.0 & 2.8 & 3.1 & $23 \mathrm{k}$ & $15 \mathrm{k}$ & $6.8 \mathrm{k}$ & $45 \mathrm{k}$ \\
\hline Sana, Yemen & 1.1 & 2.5 & 4.0 & 1.5 & 3.2 & 3.0 & 2.8 & 3.1 & $9.2 \mathrm{k}$ & $1.1 \mathrm{k}$ & $1.1 \mathrm{k}$ & $11 \mathrm{k}$ \\
\hline Tehran, Iran & 2.4 & 3.5 & 3.9 & 2.6 & 3.0 & 2.9 & 2.8 & 2.9 & $63 \mathrm{k}$ & $11 \mathrm{k}$ & $7.7 \mathrm{k}$ & $82 \mathrm{k}$ \\
\hline Hyderabad, India & 2.6 & 3.1 & 3.8 & 3.1 & 2.9 & 2.9 & 2.8 & 2.9 & $53 \mathrm{k}$ & $41 \mathrm{k}$ & $43 \mathrm{k}$ & $140 \mathrm{k}$ \\
\hline Halle, Germany & 1.1 & 2.9 & 3.8 & 1.5 & 3.3 & 3.0 & 2.8 & 3.2 & $2.9 \mathrm{k}$ & 960 & 180 & $4.1 \mathrm{k}$ \\
\hline Modesto, United States & 3.1 & 3.6 & 3.7 & 3.4 & 2.9 & 2.8 & 2.8 & 2.8 & $7.3 \mathrm{k}$ & $3.2 \mathrm{k}$ & $2.6 \mathrm{k}$ & $13 \mathrm{k}$ \\
\hline Rovno, Ukraine & 2.3 & 3.1 & 3.7 & 3.0 & 3.1 & 2.8 & 2.8 & 2.9 & 930 & 250 & $1.3 \mathrm{k}$ & $2.5 \mathrm{k}$ \\
\hline Milan, Iтацy & 1.9 & 3.6 & 3.7 & 2.9 & 3.1 & 2.8 & 2.7 & 2.9 & $58 \mathrm{k}$ & $48 \mathrm{k}$ & $31 \mathrm{k}$ & $140 \mathrm{k}$ \\
\hline Lausanne, Switzerland & 1.3 & 2.7 & 3.7 & 1.8 & 3.4 & 3.1 & 2.8 & 3.2 & $2.6 \mathrm{k}$ & $1.1 \mathrm{k}$ & 290 & $4.1 \mathrm{k}$ \\
\hline Haikou, Сhina & 2.8 & 2.6 & 3.7 & 3.0 & 3.1 & 3.1 & 2.9 & 3.0 & $1.2 \mathrm{k}$ & 460 & $1 \mathrm{k}$ & $2.6 \mathrm{k}$ \\
\hline Hong Kong, Сhina & 0.7 & 1.7 & 3.7 & 0.9 & 3.4 & 3.3 & 3.0 & 3.4 & $5.1 \mathrm{k}$ & 820 & 220 & $6.1 \mathrm{k}$ \\
\hline Auckland, New Zealand & 3.2 & 4.0 & 3.7 & 3.3 & 2.9 & 2.9 & 3.0 & 2.9 & $17 \mathrm{k}$ & $1.8 \mathrm{k}$ & $1.7 \mathrm{k}$ & $20 \mathrm{k}$ \\
\hline Osaka, JAPAN & 1.2 & 2.8 & 3.7 & 1.3 & 3.2 & 3.0 & 2.9 & 3.2 & $160 \mathrm{k}$ & $12 \mathrm{k}$ & $2.7 \mathrm{k}$ & $180 \mathrm{k}$ \\
\hline Kabul, Afghanistan & 3.6 & 3.7 & 3.6 & 3.6 & 2.8 & 2.8 & 2.8 & 2.8 & $12 \mathrm{k}$ & $1.9 \mathrm{k}$ & $7 \mathrm{k}$ & $21 \mathrm{k}$ \\
\hline Qom, Iran & 1.9 & 2.3 & 3.6 & 2.2 & 3.1 & 3.1 & 2.9 & 3.0 & $7.2 \mathrm{k}$ & $1.7 \mathrm{k}$ & $2.2 \mathrm{k}$ & $11 \mathrm{k}$ \\
\hline Malatya, Turkey & 1.1 & 2.6 & 3.6 & 1.6 & 3.2 & 3.0 & 2.8 & 3.1 & $3.8 \mathrm{k}$ & 730 & 830 & $5.3 \mathrm{k}$ \\
\hline Jaipur, India & 2.6 & 3.1 & 3.6 & 3.1 & 3.0 & 2.9 & 2.8 & 2.9 & $8.6 \mathrm{k}$ & $19 \mathrm{k}$ & $13 \mathrm{k}$ & $40 \mathrm{k}$ \\
\hline Nakuru, Kenya & 1.8 & 3.5 & 3.5 & 2.5 & 3.1 & 2.9 & 2.8 & 3.0 & 820 & 180 & 650 & $1.6 \mathrm{k}$ \\
\hline Shymkent, Kazakhstan & 3.6 & 3.3 & 3.5 & 3.5 & 2.9 & 2.9 & 2.9 & 2.9 & $4.3 \mathrm{k}$ & 830 & $4.4 \mathrm{k}$ & $9.5 \mathrm{k}$ \\
\hline Kigali, Rwanda & 3.0 & 3.3 & 3.5 & 3.3 & 3.0 & 2.9 & 2.9 & 2.9 & 980 & $1.9 \mathrm{k}$ & $1.7 \mathrm{k}$ & $4.6 \mathrm{k}$ \\
\hline Culiacan, Mexico & 0.7 & 2.0 & 3.5 & 1.5 & 3.4 & 3.2 & 3.0 & 3.3 & $8.2 \mathrm{k}$ & $3.6 \mathrm{k}$ & $3.5 \mathrm{k}$ & $15 \mathrm{k}$ \\
\hline Beira, Mozambique & 2.5 & 4.5 & 3.5 & 3.2 & 3.0 & 2.9 & 2.8 & 2.9 & $1.3 \mathrm{k}$ & 110 & $2 \mathrm{k}$ & $3.4 \mathrm{k}$ \\
\hline Tangshan, China & 2.9 & 3.1 & 3.4 & 3.3 & 3.0 & 3.0 & 2.8 & 2.9 & $1.7 \mathrm{k}$ & 870 & $3.1 \mathrm{k}$ & $5.6 \mathrm{k}$ \\
\hline Tel Aviv, Israel & 1.1 & 2.5 & 3.4 & 2.0 & 3.2 & 3.1 & 3.0 & 3.1 & $9.6 \mathrm{k}$ & $14 \mathrm{k}$ & $4.2 \mathrm{k}$ & $28 \mathrm{k}$ \\
\hline Hindupur, India & & & 3.4 & 2.7 & & & 3.0 & 3.0 & 32 & 42 & 250 & 320 \\
\hline Myeik, Myanmar & 1.9 & 3.3 & 3.3 & 2.4 & 3.1 & 2.8 & 2.8 & 3.0 & 720 & 140 & 500 & $1.4 \mathrm{k}$ \\
\hline Palermo, Italy & 2.2 & 6.4 & 3.3 & 2.6 & 3.0 & 2.5 & 2.8 & 2.9 & $7.1 \mathrm{k}$ & 220 & $3.5 \mathrm{k}$ & $11 \mathrm{k}$ \\
\hline Montreal, Canada & 1.8 & 3.5 & 3.3 & 1.9 & 3.3 & 3.0 & 3.1 & 3.2 & $45 \mathrm{k}$ & $2.4 \mathrm{k}$ & $4.7 \mathrm{k}$ & $52 \mathrm{k}$ \\
\hline Port Elizabeth, South Africa & 2.3 & 4.2 & 3.3 & 2.7 & 3.0 & 2.8 & 3.0 & 3.0 & $9.1 \mathrm{k}$ & 990 & $6.3 \mathrm{k}$ & $16 \mathrm{k}$ \\
\hline
\end{tabular}




\begin{tabular}{|c|c|c|c|c|c|c|c|c|c|c|c|c|}
\hline & & Sprawl & SNDi) & & & Nodal & legree & & & $\mathrm{N}(\mathrm{n}$ & des) & \\
\hline & $<1990$ & $90-99$ & '00-13 & Stock & $<1990$ & $90-99$ & '00-13 & Stock & $<1990$ & $90-99$ & '00-13 & Stock \\
\hline Paris, France & 1.8 & 3.0 & 3.3 & 2.0 & 3.1 & 2.9 & 2.8 & 3.1 & $120 \mathrm{k}$ & $13 \mathrm{k}$ & $11 \mathrm{k}$ & $140 \mathrm{k}$ \\
\hline Alexandria, Egypt & 0.7 & 2.3 & 3.3 & 1.1 & 3.3 & 3.0 & 2.9 & 3.2 & $8.2 \mathrm{k}$ & $1.2 \mathrm{k}$ & $1.8 \mathrm{k}$ & $11 \mathrm{k}$ \\
\hline Antwerp, Belgium & 1.5 & 2.8 & 3.2 & 1.9 & 3.2 & 2.9 & 2.8 & 3.1 & $16 \mathrm{k}$ & $6.2 \mathrm{k}$ & $1.1 \mathrm{k}$ & $23 \mathrm{k}$ \\
\hline Ahmedabad, India & 2.5 & 3.5 & 3.2 & 2.7 & 3.0 & 2.8 & 2.9 & 2.9 & $8.9 \mathrm{k}$ & $1.5 \mathrm{k}$ & $1.5 \mathrm{k}$ & $12 \mathrm{k}$ \\
\hline Saint Petersburg, Russia & 0.5 & 3.4 & 3.2 & 1.9 & 3.6 & 2.9 & 3.0 & 3.3 & $9.6 \mathrm{k}$ & $3.6 \mathrm{k}$ & $6.8 \mathrm{k}$ & $20 \mathrm{k}$ \\
\hline Palmas, BraziL & 3.1 & 3.5 & 3.2 & 3.3 & 3.1 & 2.9 & 3.1 & 3.0 & $1.2 \mathrm{k}$ & $3 \mathrm{k}$ & $1.1 \mathrm{k}$ & $5.3 \mathrm{k}$ \\
\hline Lahore, Pakistan & 2.3 & 2.8 & 3.2 & 2.5 & 3.0 & 2.9 & 3.0 & 3.0 & $25 \mathrm{k}$ & $6 \mathrm{k}$ & $8.7 \mathrm{k}$ & $40 \mathrm{k}$ \\
\hline Oyo, Nigeria & 3.4 & 3.4 & 3.2 & 3.3 & 2.7 & 2.8 & 2.8 & 2.8 & $1.5 \mathrm{k}$ & 780 & $2.3 \mathrm{k}$ & $4.5 \mathrm{k}$ \\
\hline Kinshasa, DR ConGo & 2.1 & 3.2 & 3.2 & 2.7 & 3.2 & 3.0 & 2.9 & 3.1 & $19 \mathrm{k}$ & $13 \mathrm{k}$ & $15 \mathrm{k}$ & $46 \mathrm{k}$ \\
\hline Shanghai, Снina & 1.6 & 2.9 & 3.1 & 2.1 & 3.3 & 3.1 & 3.1 & 3.2 & $22 \mathrm{k}$ & $10 \mathrm{k}$ & $4.3 \mathrm{k}$ & $36 \mathrm{k}$ \\
\hline Zunyi, Снina & 3.6 & 3.4 & 3.1 & 3.3 & 2.9 & 3.0 & 3.1 & 3.0 & 450 & 210 & 400 & $1.1 \mathrm{k}$ \\
\hline Seoul, South Korea & 0.9 & 2.3 & 3.1 & 1.2 & 3.2 & 3.1 & 3.0 & 3.2 & $87 \mathrm{k}$ & $23 \mathrm{k}$ & $15 \mathrm{k}$ & $130 \mathrm{k}$ \\
\hline Guixi, China & 1.3 & & 3.1 & 2.5 & 3.0 & & 2.8 & 2.9 & 120 & 98 & 150 & 370 \\
\hline Vienna, Austria & 0.5 & 2.3 & 3.0 & 1.0 & 3.4 & 3.0 & 2.9 & 3.3 & $16 \mathrm{k}$ & $5.9 \mathrm{k}$ & $1.5 \mathrm{k}$ & $23 \mathrm{k}$ \\
\hline Tebessa, Algeria & 2.0 & 2.6 & 3.0 & 2.2 & 3.1 & 3.1 & 2.9 & 3.1 & $2.5 \mathrm{k}$ & 850 & 370 & $3.8 \mathrm{k}$ \\
\hline Shenzhen, Снina & 2.5 & 2.6 & 3.0 & 2.7 & 3.1 & 3.1 & 3.0 & 3.1 & $6.8 \mathrm{k}$ & $10 \mathrm{k}$ & $5.6 \mathrm{k}$ & $23 \mathrm{k}$ \\
\hline Reynosa, Mexico & 1.9 & 2.9 & 3.0 & 2.2 & 3.2 & 3.2 & 3.0 & 3.2 & $7.5 \mathrm{k}$ & 720 & $3 \mathrm{k}$ & $11 \mathrm{k}$ \\
\hline Oldenburg, Germany & 2.0 & 3.0 & 3.0 & 2.2 & 3.2 & 3.0 & 2.9 & 3.1 & $2.5 \mathrm{k}$ & 670 & 400 & $3.5 \mathrm{k}$ \\
\hline Guangzhou, Сhina & 1.8 & 2.8 & 2.9 & 2.8 & 3.2 & 3.0 & 3.0 & 3.0 & $5.6 \mathrm{k}$ & $34 \mathrm{k}$ & $33 \mathrm{k}$ & $73 \mathrm{k}$ \\
\hline Baghdad, Iraq & 2.1 & 3.3 & 2.9 & 2.2 & 3.1 & 2.8 & 2.9 & 3.1 & $45 \mathrm{k}$ & 800 & $1.1 \mathrm{k}$ & $47 \mathrm{k}$ \\
\hline Gomel, Belarus & 1.6 & 2.4 & 2.9 & 2.0 & 3.3 & 3.0 & 2.9 & 3.1 & $1.4 \mathrm{k}$ & $1.1 \mathrm{k}$ & 190 & $2.7 \mathrm{k}$ \\
\hline Riyadh, Saudi Arabia & 1.7 & 2.7 & 2.9 & 2.1 & 3.2 & 3.1 & 3.1 & 3.1 & $50 \mathrm{k}$ & $14 \mathrm{k}$ & $26 \mathrm{k}$ & $90 \mathrm{k}$ \\
\hline Qingdao, Снina & 1.6 & 1.0 & 2.8 & 2.4 & 3.2 & 3.2 & 3.0 & 3.0 & $2.7 \mathrm{k}$ & $2.3 \mathrm{k}$ & $14 \mathrm{k}$ & $19 \mathrm{k}$ \\
\hline Singapore, Singapore & 1.9 & 1.5 & 2.8 & 1.9 & 3.3 & 3.4 & 3.2 & 3.3 & $14 \mathrm{k}$ & $2.3 \mathrm{k}$ & 620 & $17 \mathrm{k}$ \\
\hline Cochabamba, Bolivia & 0.6 & 2.2 & 2.8 & 1.6 & 3.4 & 3.1 & 3.0 & 3.2 & $9.5 \mathrm{k}$ & $6.2 \mathrm{k}$ & $5.8 \mathrm{k}$ & $21 \mathrm{k}$ \\
\hline Cairo, EgYPT & 1.4 & 2.2 & 2.7 & 2.1 & 3.2 & 3.1 & 3.1 & 3.1 & $23 \mathrm{k}$ & $5.1 \mathrm{k}$ & $33 \mathrm{k}$ & $62 \mathrm{k}$ \\
\hline Cordoba, Argentina & 0.6 & 2.3 & 2.7 & 1.0 & 3.4 & 3.2 & 3.1 & 3.3 & $22 \mathrm{k}$ & $2.4 \mathrm{k}$ & $4.5 \mathrm{k}$ & $29 \mathrm{k}$ \\
\hline Xingping, Снina & 2.4 & & 2.7 & 2.5 & 3.0 & & 2.9 & 2.9 & 110 & 34 & 260 & 410 \\
\hline Beijing, Снina & 2.0 & 2.7 & 2.7 & 2.3 & 3.2 & 3.1 & 3.1 & 3.1 & $19 \mathrm{k}$ & $4.6 \mathrm{k}$ & $15 \mathrm{k}$ & $39 \mathrm{k}$ \\
\hline Bukhara, UzBekistan & 0.9 & 2.9 & 2.7 & 2.5 & 3.3 & 2.9 & 2.9 & 2.9 & 380 & 910 & $1.3 \mathrm{k}$ & $2.6 \mathrm{k}$ \\
\hline Belgaum, India & 1.2 & 2.1 & 2.7 & 2.2 & 3.1 & 3.1 & 3.0 & 3.1 & 560 & 740 & $1.5 \mathrm{k}$ & $2.8 \mathrm{k}$ \\
\hline Taipei, Снina & 0.4 & 1.9 & 2.6 & 1.2 & 3.4 & 3.1 & 3.0 & 3.2 & $15 \mathrm{k}$ & $9.3 \mathrm{k}$ & $7.7 \mathrm{k}$ & $33 \mathrm{k}$ \\
\hline Yulin, Сhina & 2.7 & 2.1 & 2.5 & 2.7 & 2.9 & 3.1 & 2.9 & 3.0 & 210 & 320 & 300 & 820 \\
\hline Bicheng, China & 0.2 & 0.4 & 2.5 & 1.7 & 3.3 & 3.3 & 3.1 & 3.1 & 150 & 130 & 630 & 910 \\
\hline Zwolle, Netherlands & 2.0 & 1.6 & 2.5 & 1.9 & 3.1 & 3.3 & 3.0 & 3.1 & $3.1 \mathrm{k}$ & 470 & 200 & $3.7 \mathrm{k}$ \\
\hline Tianjin, China & 1.7 & 2.9 & 2.5 & 2.3 & 3.3 & 3.1 & 3.1 & 3.1 & $5 \mathrm{k}$ & $1.2 \mathrm{k}$ & $14 \mathrm{k}$ & $20 \mathrm{k}$ \\
\hline
\end{tabular}




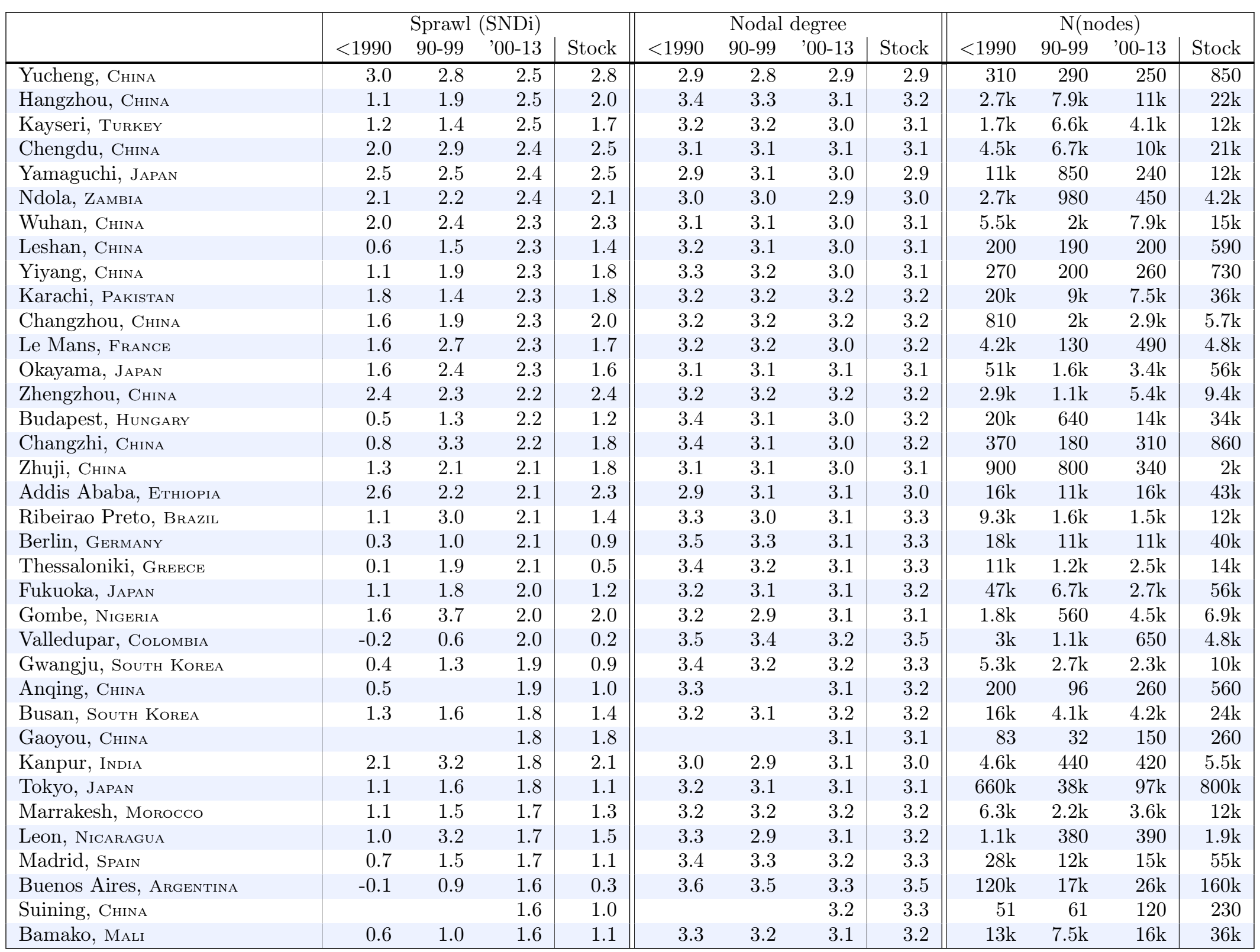




\begin{tabular}{|c|c|c|c|c|c|c|c|c|c|c|c|c|}
\hline & \multicolumn{4}{|c|}{ Sprawl (SNDi) } & \multicolumn{4}{|c|}{ Nodal degree } & \multicolumn{4}{|c|}{$\mathrm{N}($ nodes $)$} \\
\hline & $<1990$ & $90-99$ & '00-13 & Stock & $<1990$ & $90-99$ & '00-13 & Stock & $<1990$ & $90-99$ & '00-13 & Stock \\
\hline Jinju, South Korea & 0.8 & 2.4 & 1.6 & 1.2 & 3.3 & 3.2 & 3.1 & 3.2 & $2.5 \mathrm{k}$ & 120 & $2.5 \mathrm{k}$ & $5.1 \mathrm{k}$ \\
\hline Luanda, Angola & 2.0 & 2.2 & 1.5 & 1.8 & 3.0 & 3.0 & 3.1 & 3.1 & $12 \mathrm{k}$ & $10 \mathrm{k}$ & $28 \mathrm{k}$ & $51 \mathrm{k}$ \\
\hline Cheonan, South Korea & 0.2 & 0.7 & 1.3 & 0.8 & 3.4 & 3.4 & 3.2 & 3.3 & $1.6 \mathrm{k}$ & $1.2 \mathrm{k}$ & $2.6 \mathrm{k}$ & $5.3 \mathrm{k}$ \\
\hline Vinh Long, Viet NAM & & & 1.3 & 1.4 & & & 3.1 & 3.2 & 72 & 99 & 160 & 330 \\
\hline Lubumbashi, DR ConGo & 1.7 & 1.8 & 1.3 & 1.5 & 3.1 & 3.0 & 3.1 & 3.1 & $6.7 \mathrm{k}$ & $2.3 \mathrm{k}$ & $7.7 \mathrm{k}$ & $17 \mathrm{k}$ \\
\hline Jinan, China & 1.8 & 1.5 & 1.2 & 1.7 & 3.2 & 3.3 & 3.3 & 3.2 & $4.3 \mathrm{k}$ & 620 & 990 & $5.9 \mathrm{k}$ \\
\hline Yanggu, China & & & 0.7 & 0.4 & & & 3.3 & 3.4 & 79 & 66 & 130 & 280 \\
\hline Khartoum, Sudan & 0.2 & 0.6 & 0.7 & 0.5 & 3.4 & 3.3 & 3.3 & 3.3 & $56 \mathrm{k}$ & $14 \mathrm{k}$ & $38 \mathrm{k}$ & $110 \mathrm{k}$ \\
\hline Xucheng, China & & & 0.5 & 0.8 & & & 3.6 & 3.5 & 12 & 51 & 260 & 330 \\
\hline
\end{tabular}




\section{F.7 City maps}

Maps for a number of cities are available as a $\sim 300 \mathrm{MB}$ PDF at:

https://alum.mit.edu/www/cpbl/publications/draft2019sprawl/SI/all-citymaps-10.pdf

\section{F.8 World maps}

World maps for our sprawl metrics will be available at:

https://alum.mit.edu/www/cpbl/publications/draft2019sprawl/SI/world-maps

\section{F.9 World region trend plots}

In the following pages, trends of individual countries (in each region or group) are represented by colored lines, and their distribution in each time range is summarized in a box plot. Each dotted line shows the latest stock value for all nodes in the group of countries. Country ISO codes are marked in microfont. Region classifications are from the World Bank [2016]. For more detail, see the tabular data.

The following pages show results only for SNDi. Other metrics are available online at: https://alum.mit.edu/www/cpbl/publications/draft2019sprawl. 

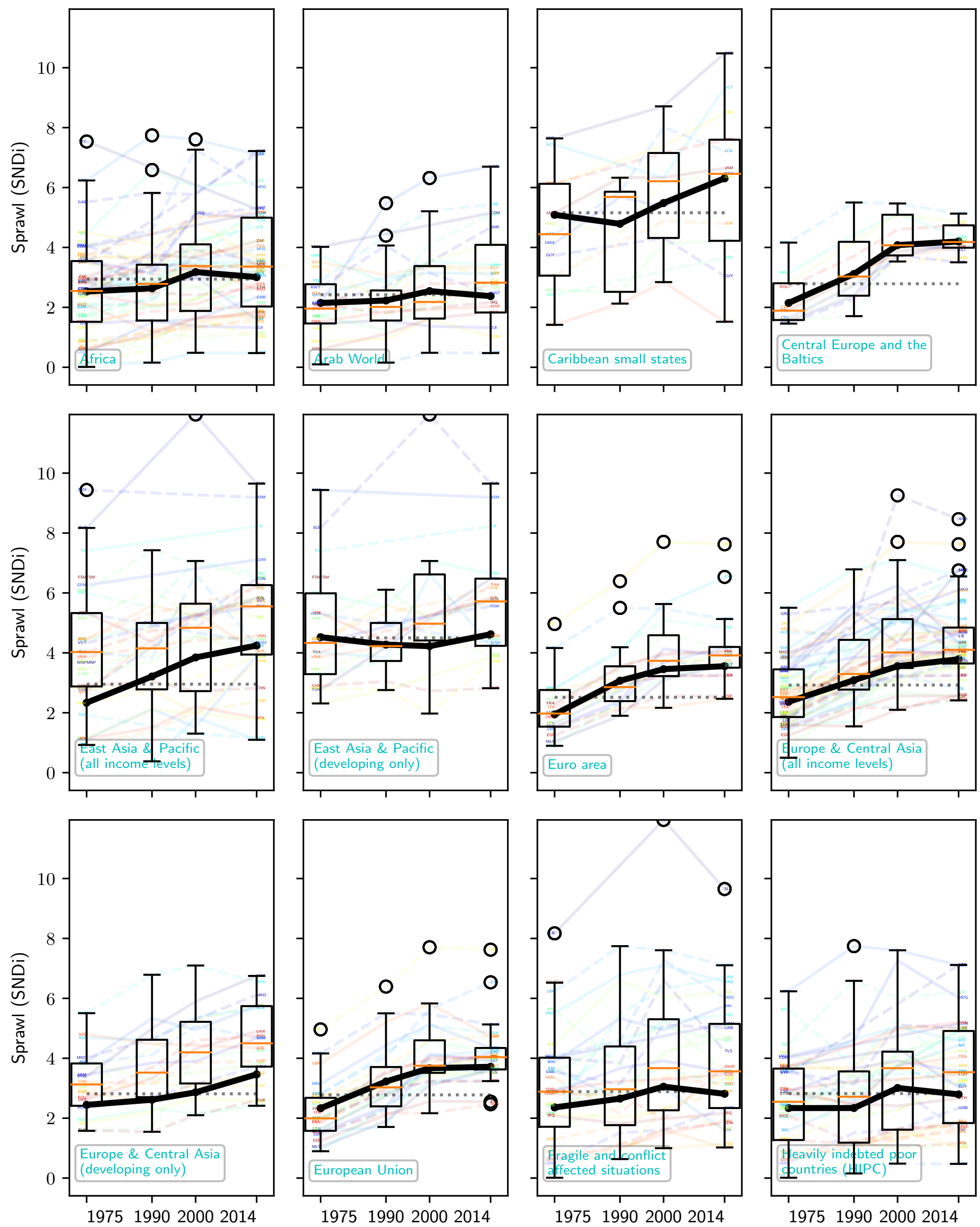

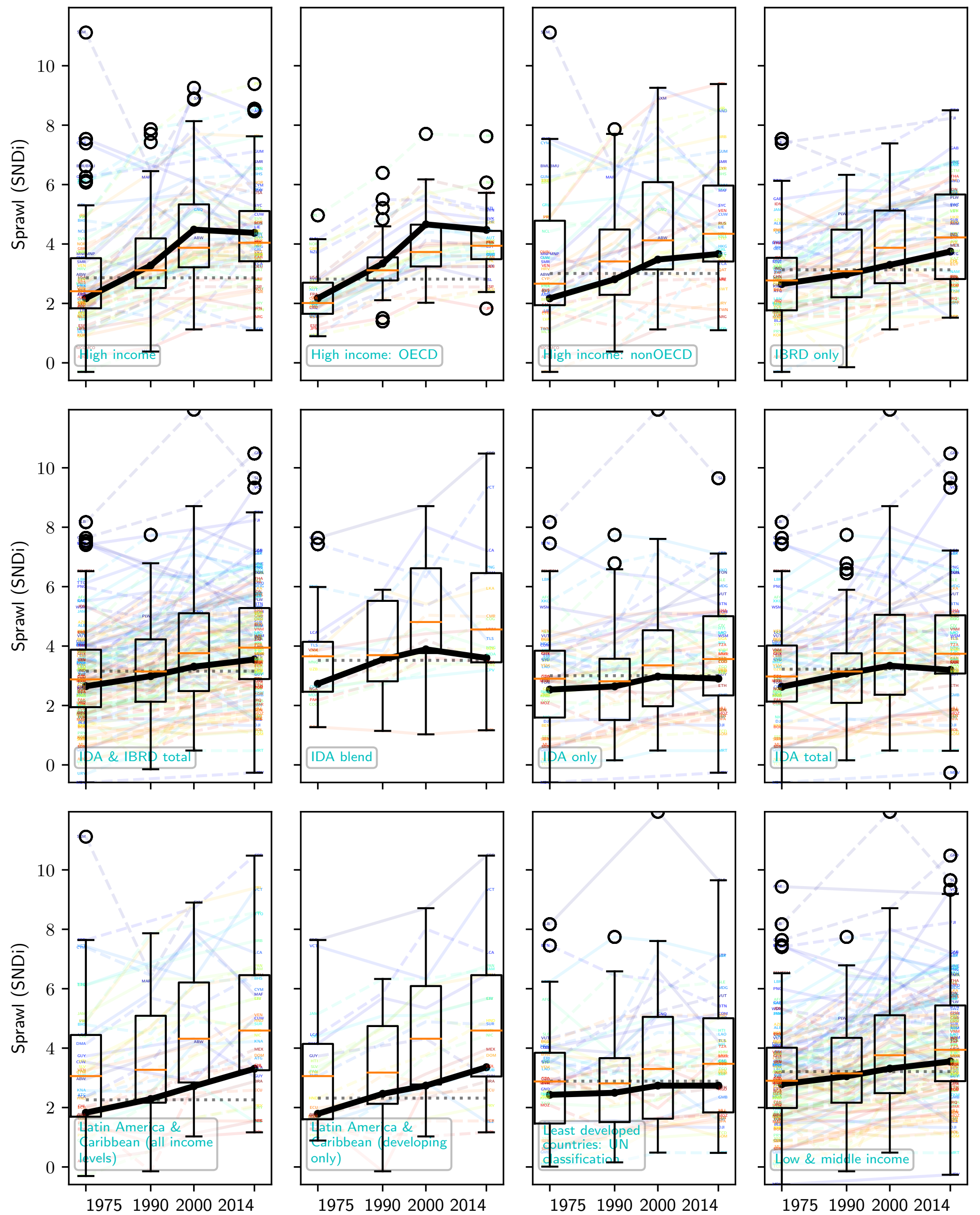

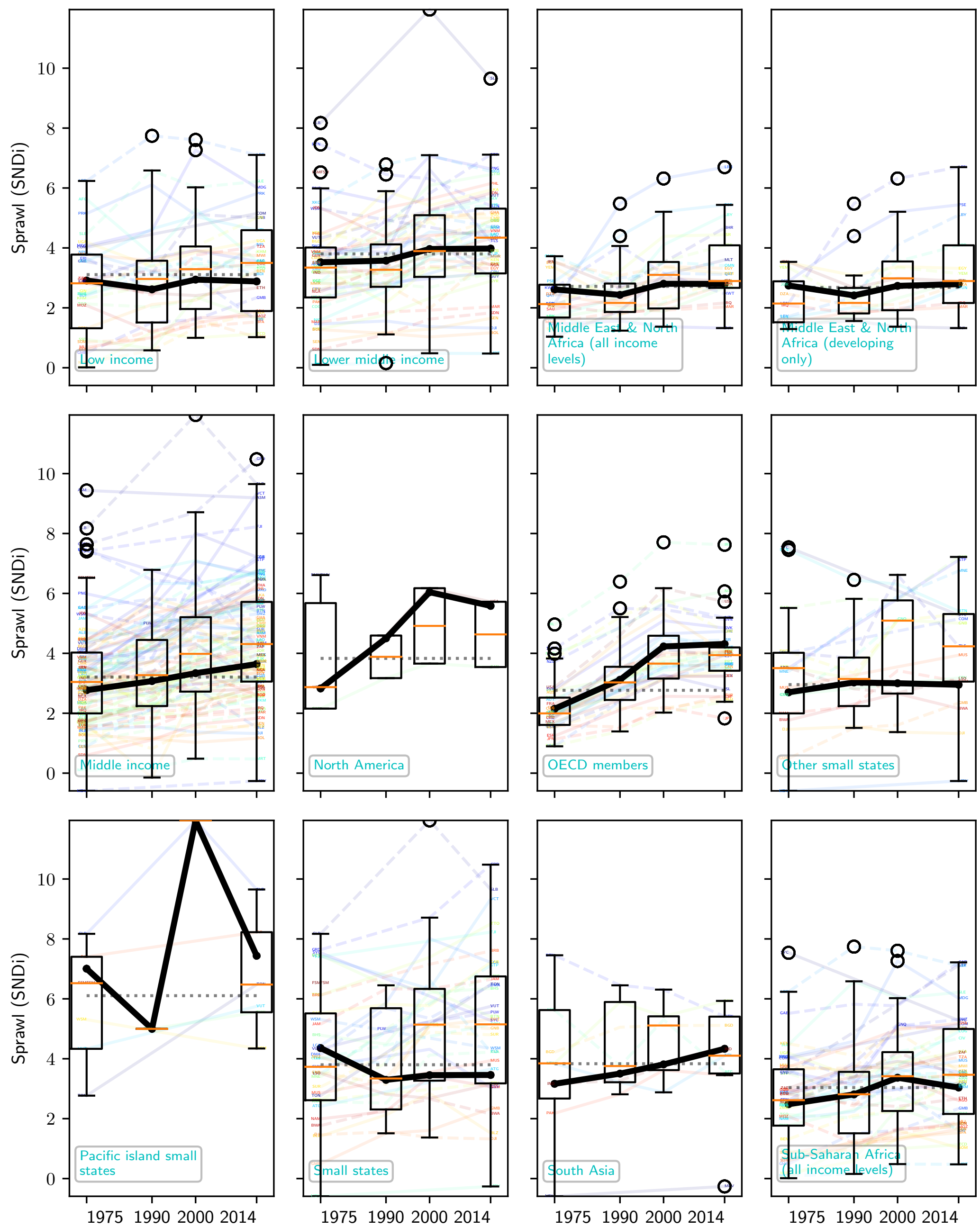

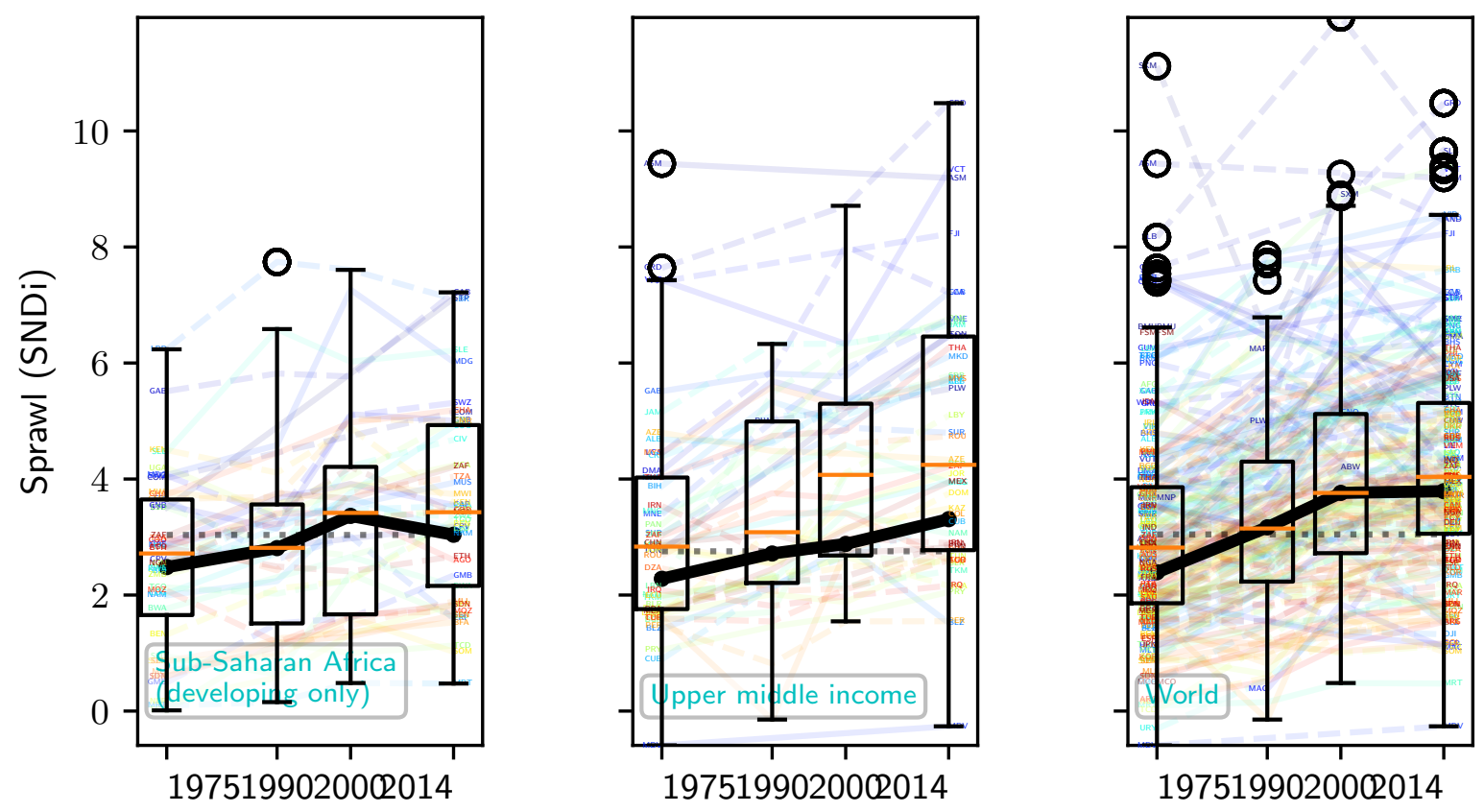


\section{F.10 Country trend plots with sub-national regional distributions}

In the following pages, box plots are used to describe the distribution, within each time period in each country, of the metric over sub-national regions (i.e., GADM level 1). The blue shaded region shows the full extent of the minimum and maximum value across these sub-national regions. The dark line shows the mean over the entire country.

The following pages show results only for SNDi. Other metrics are available online at: https://alum.mit.edu/www/cpbl/publications/draft2019sprawl. 

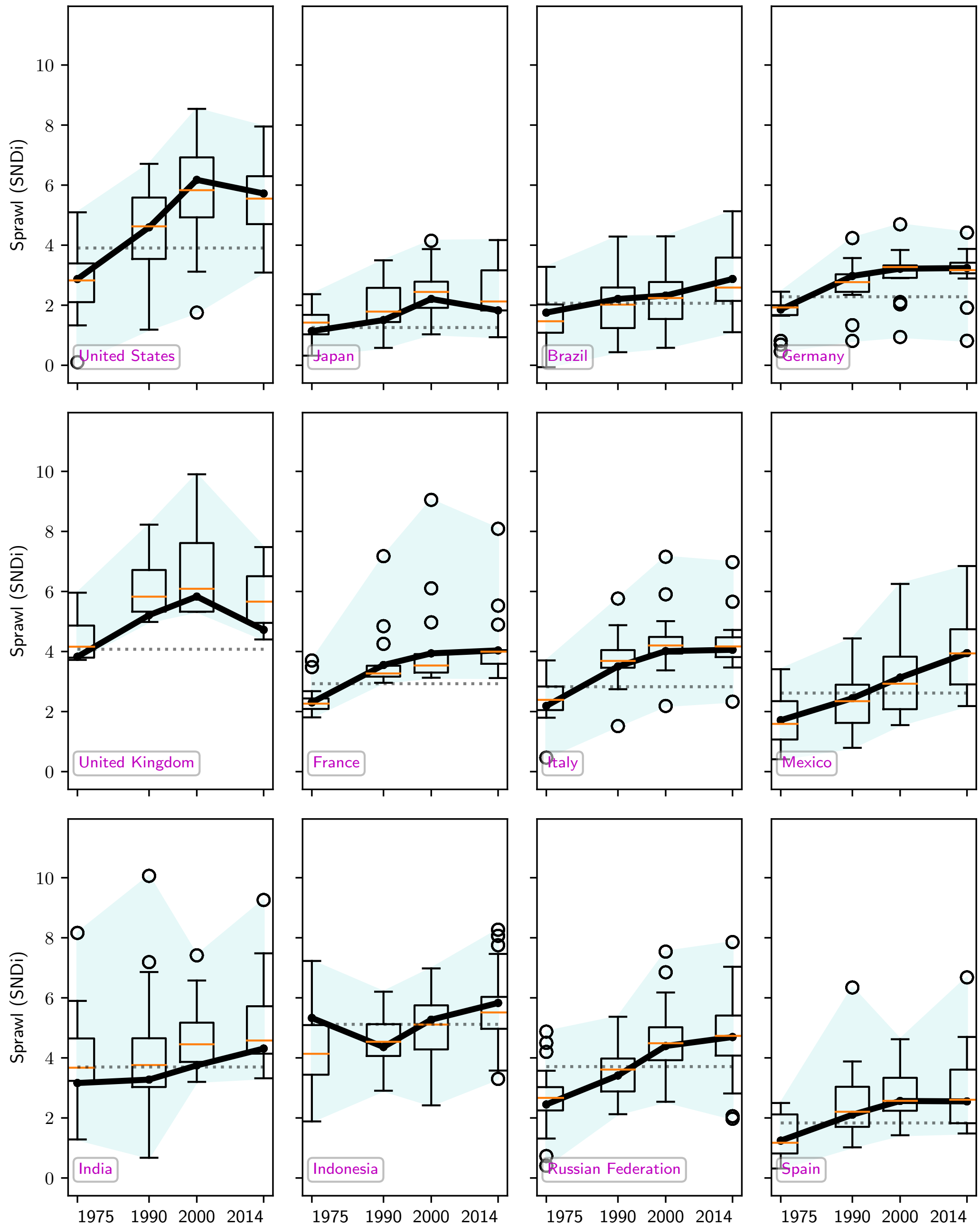

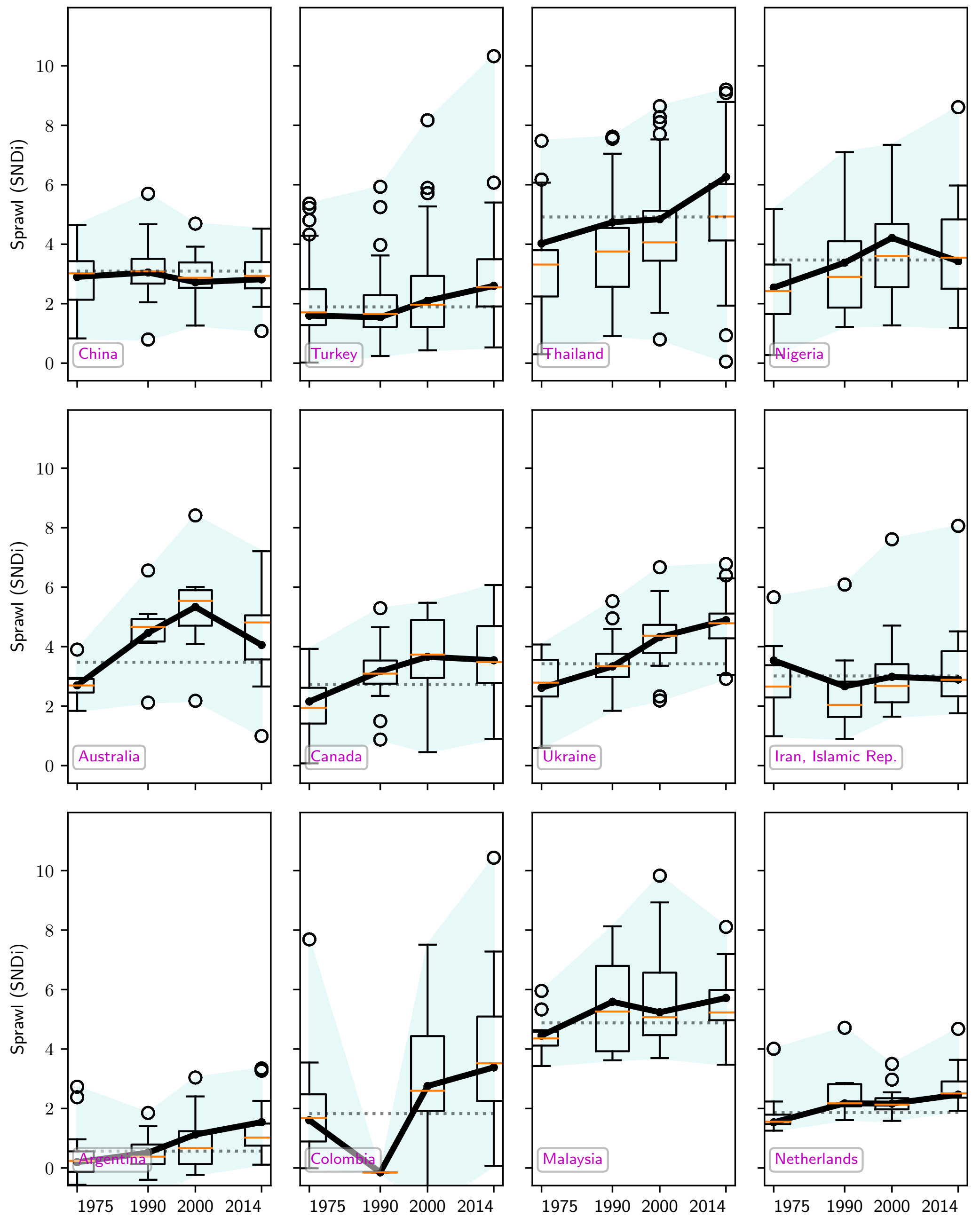

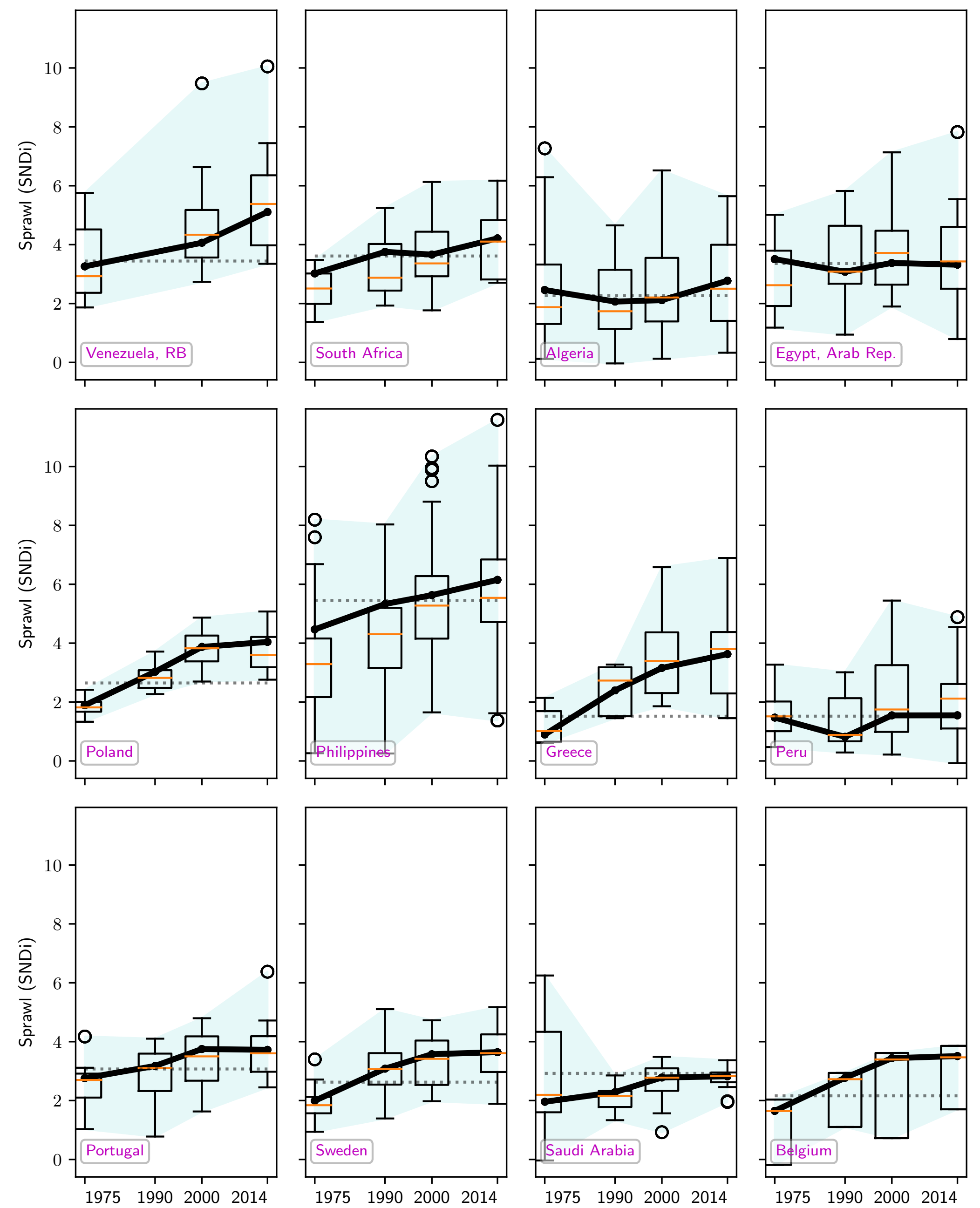

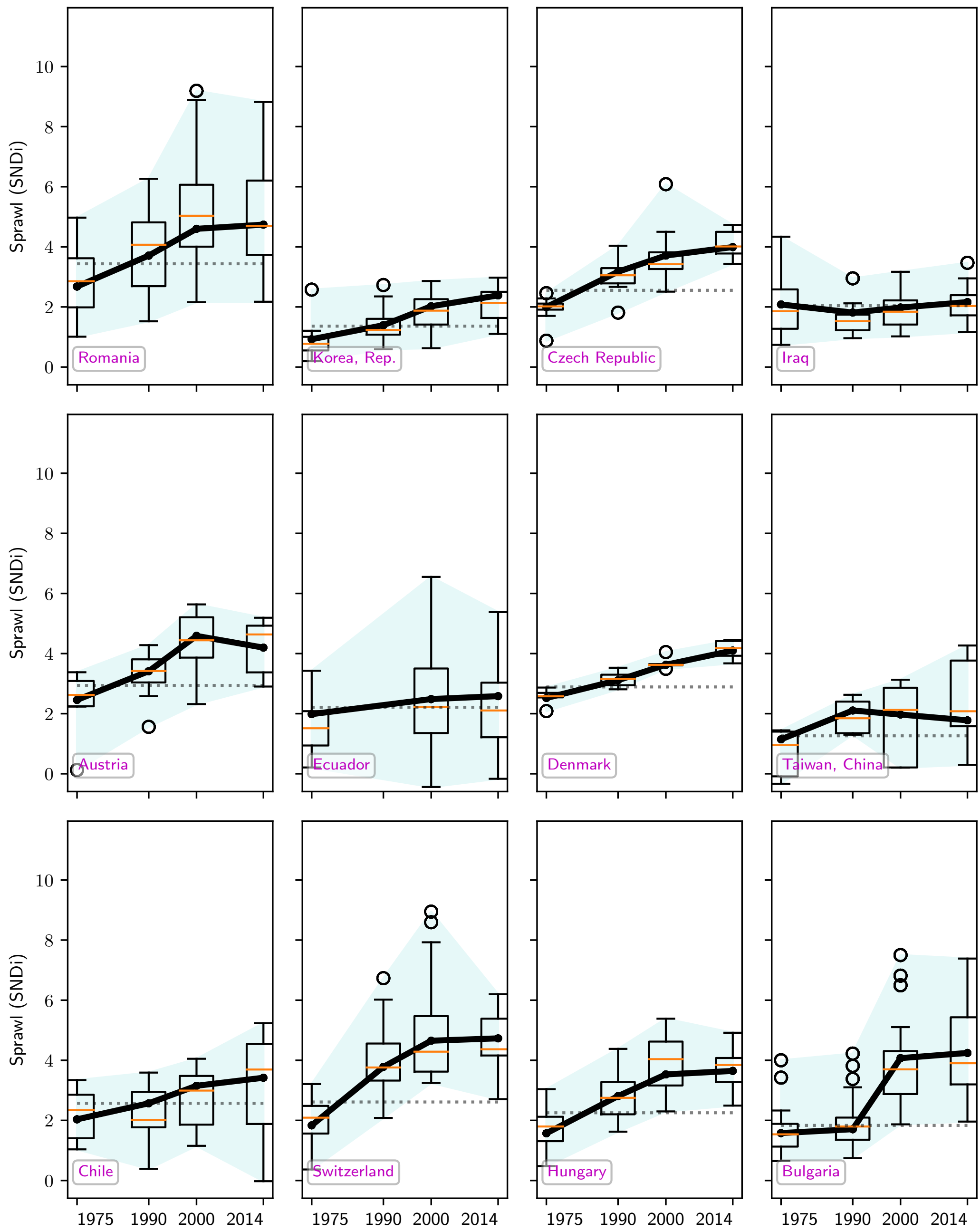

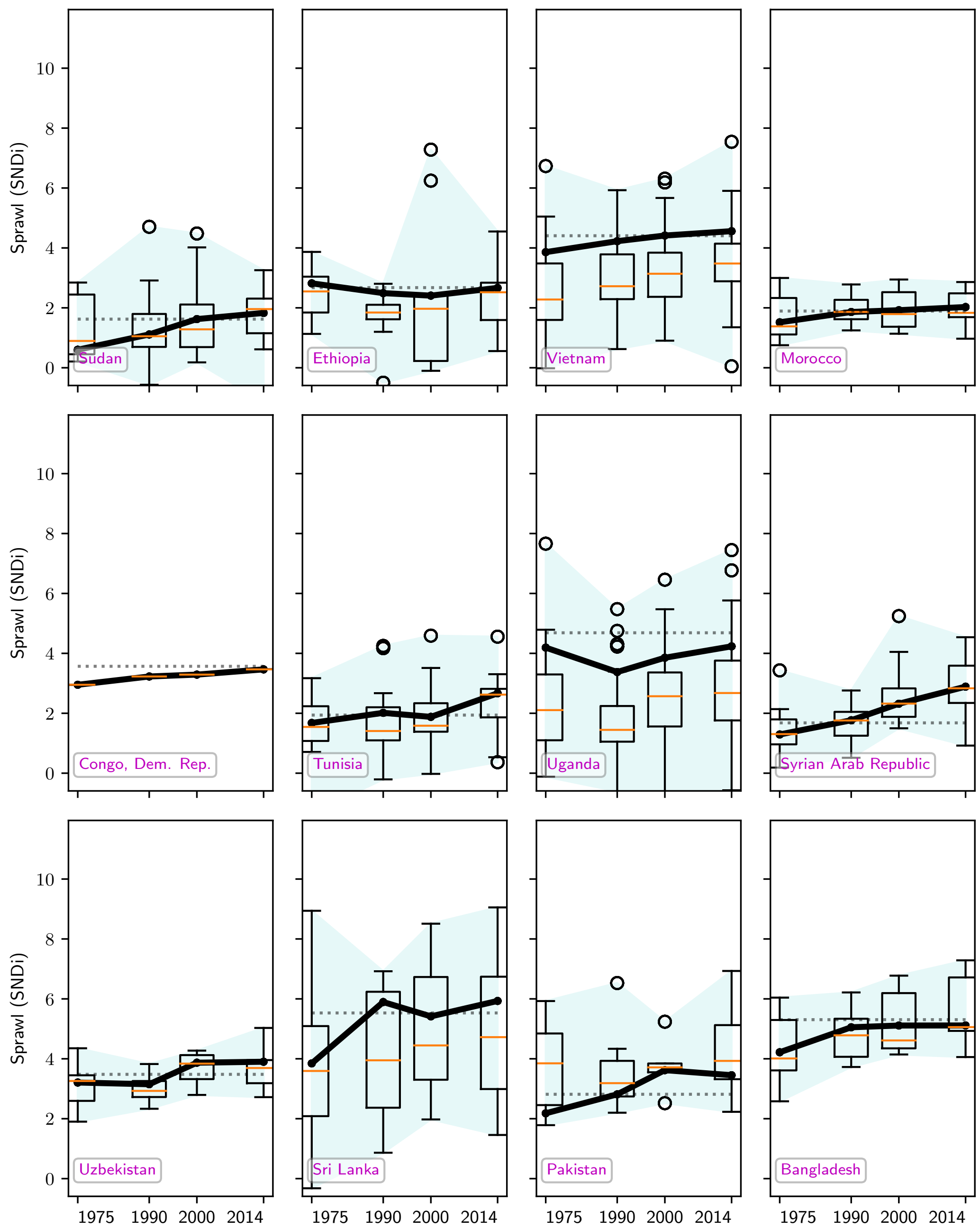

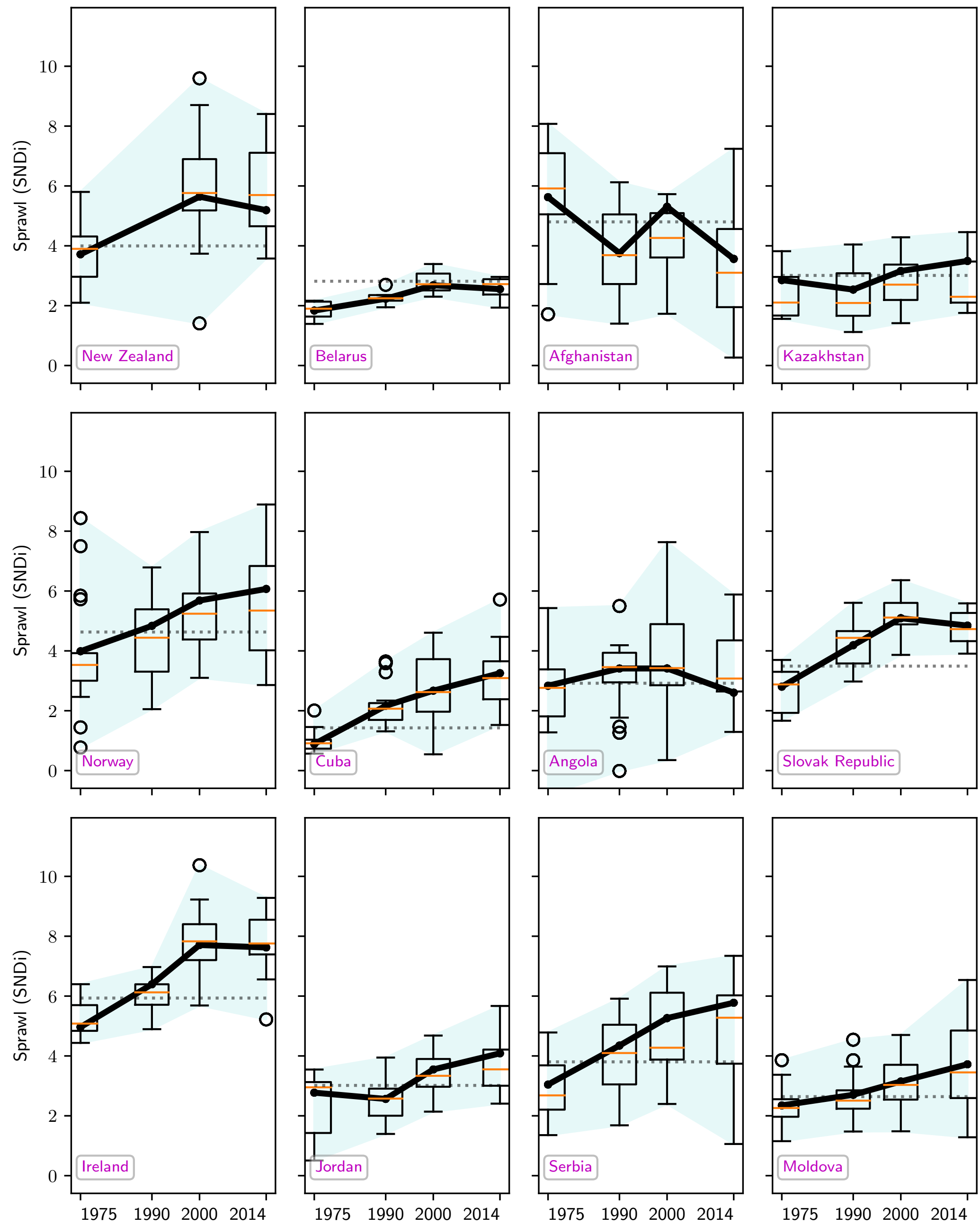

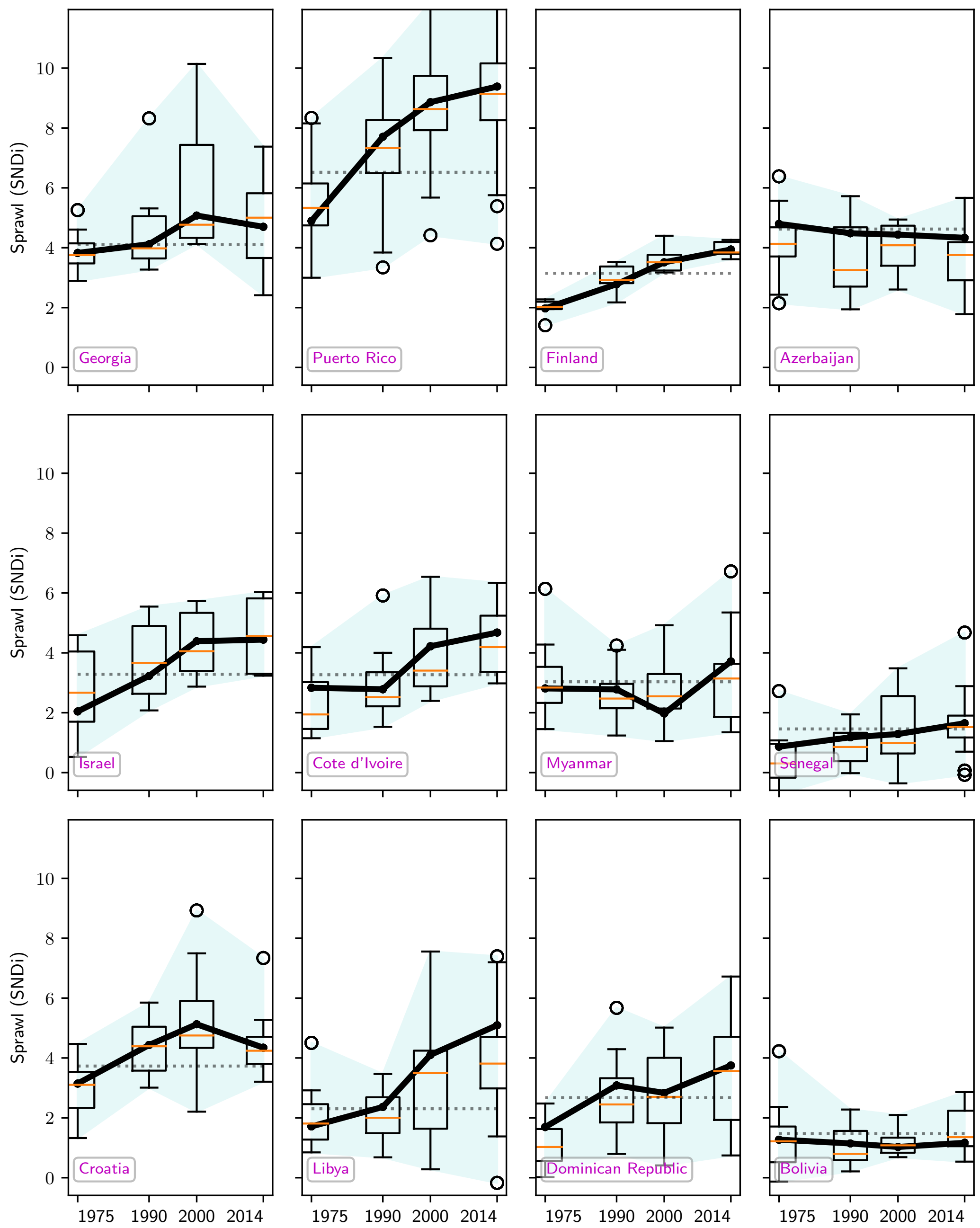

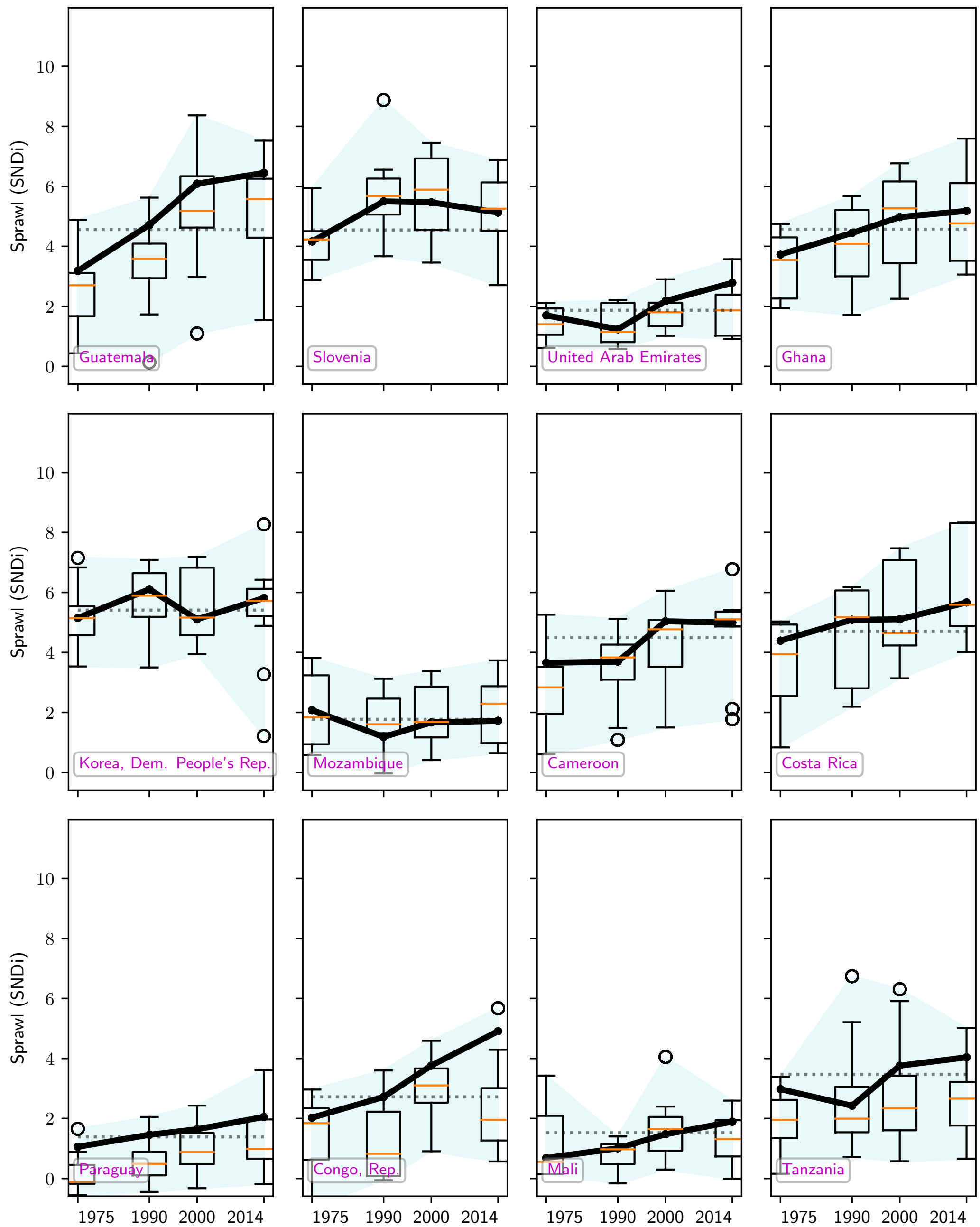

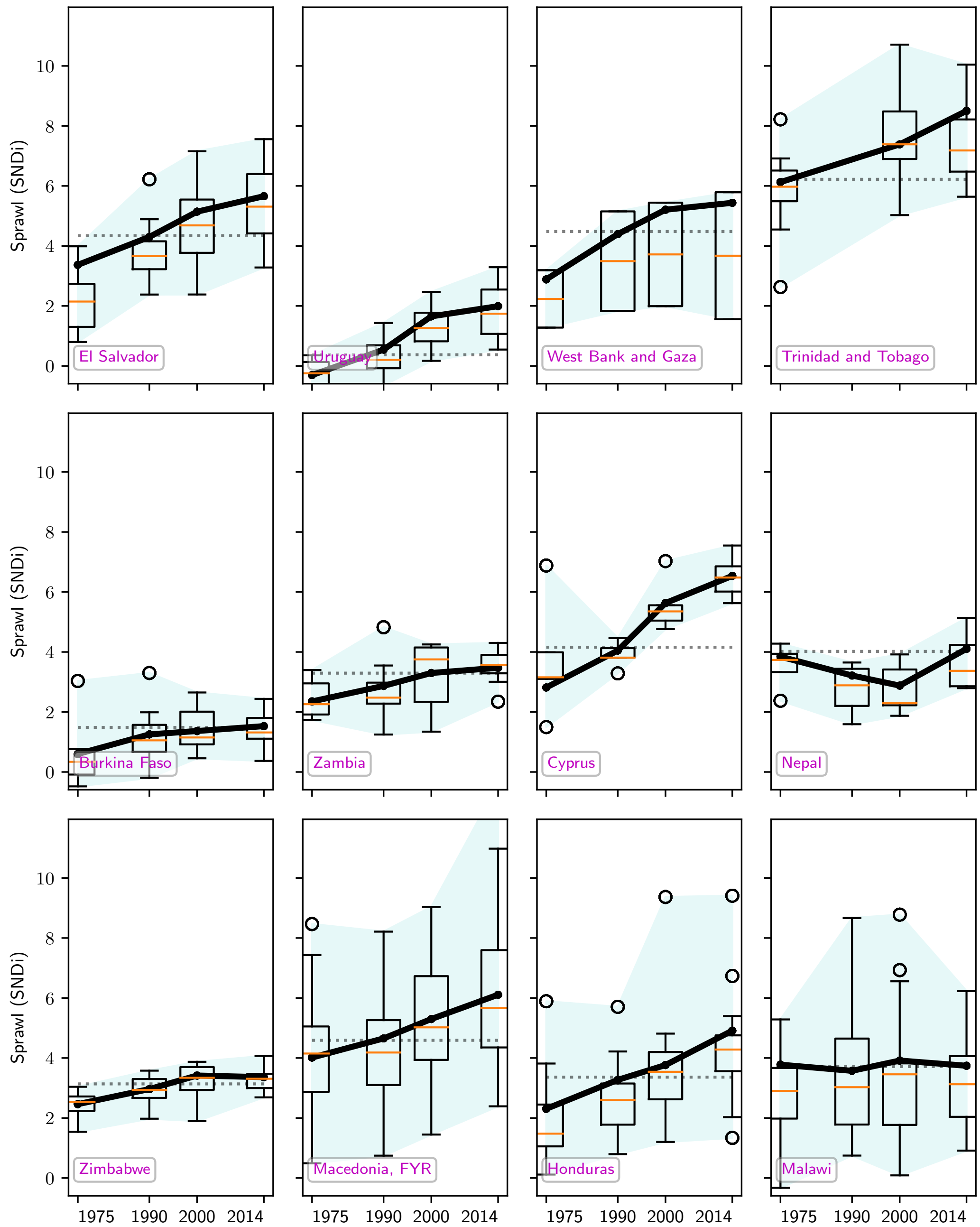

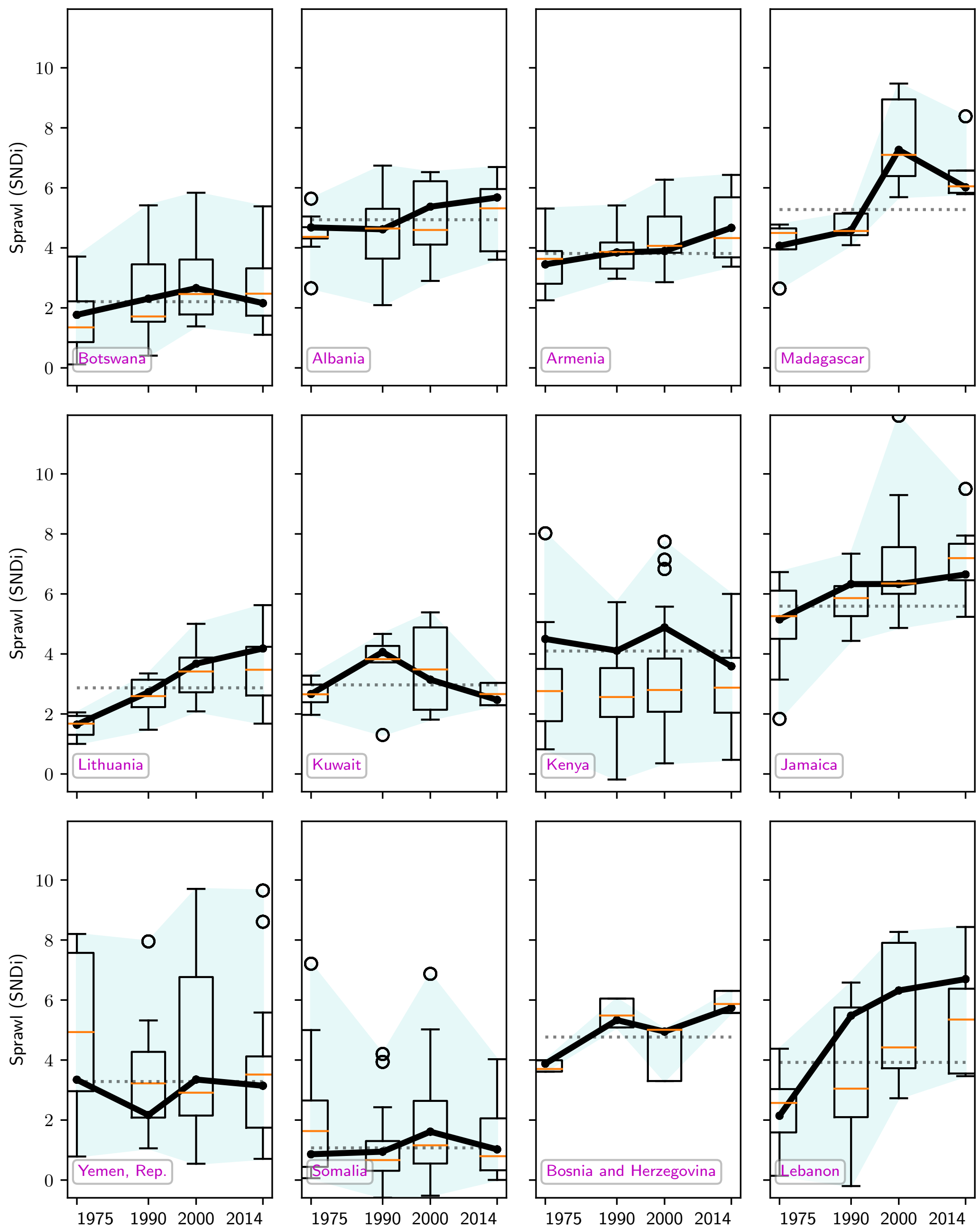

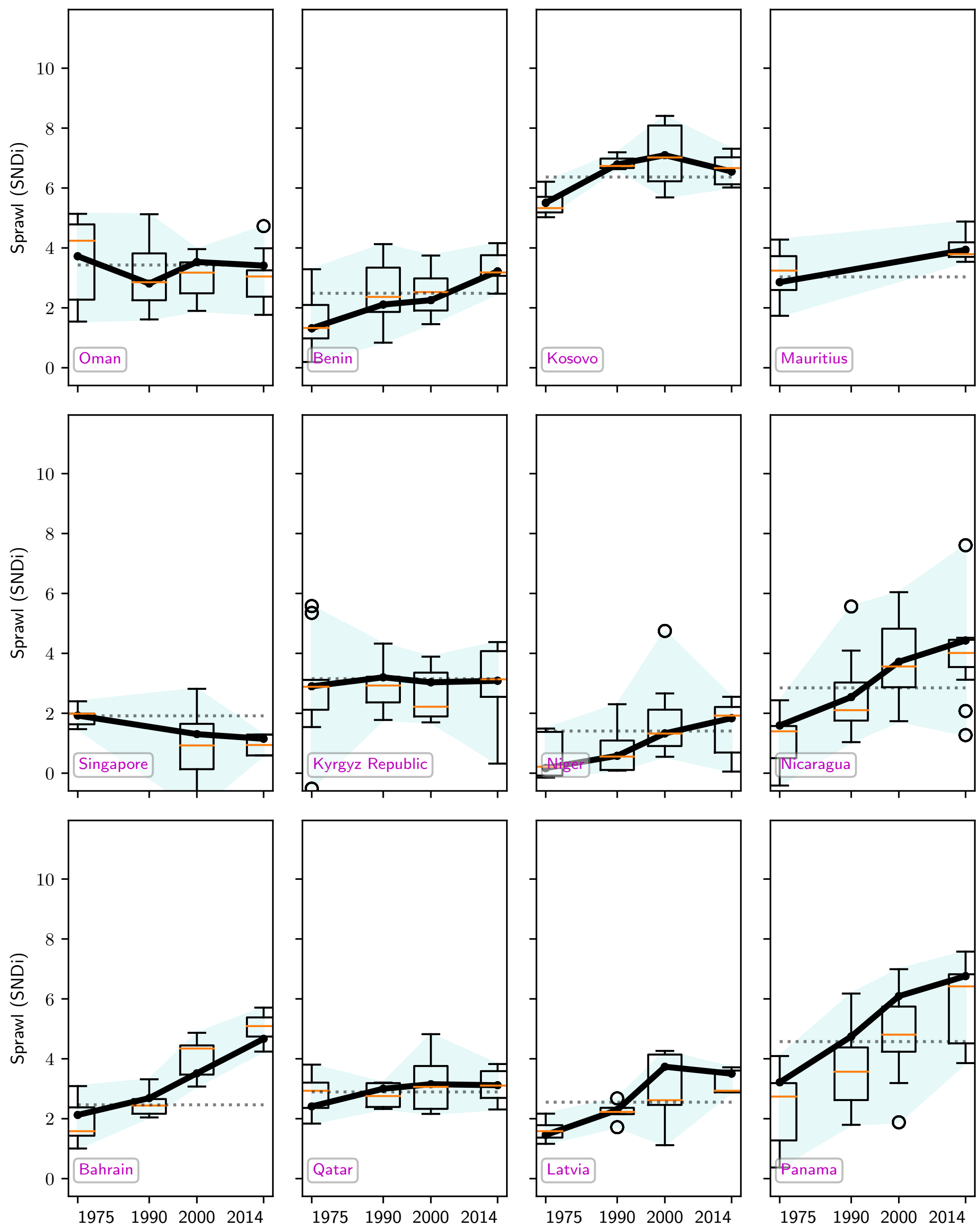

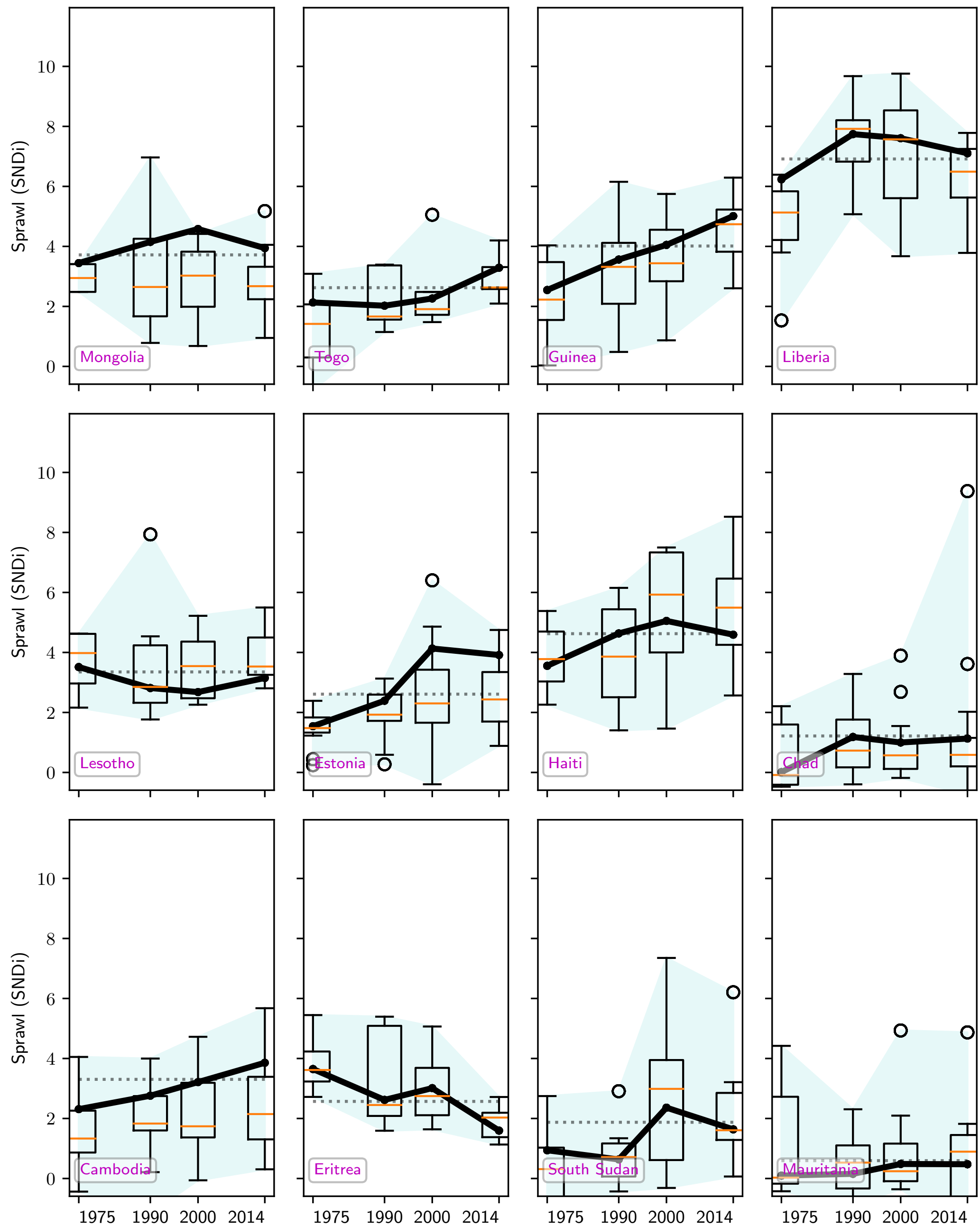

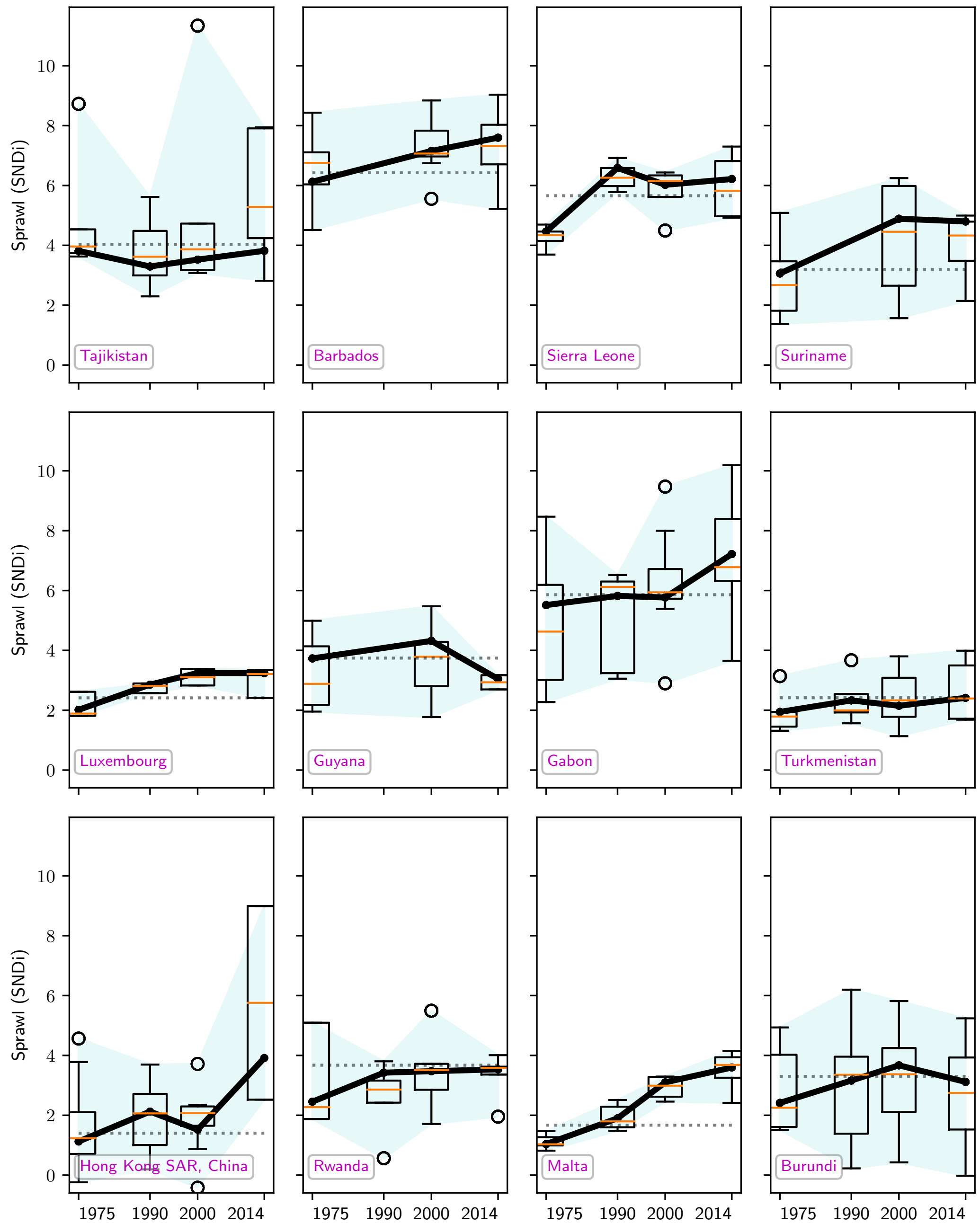

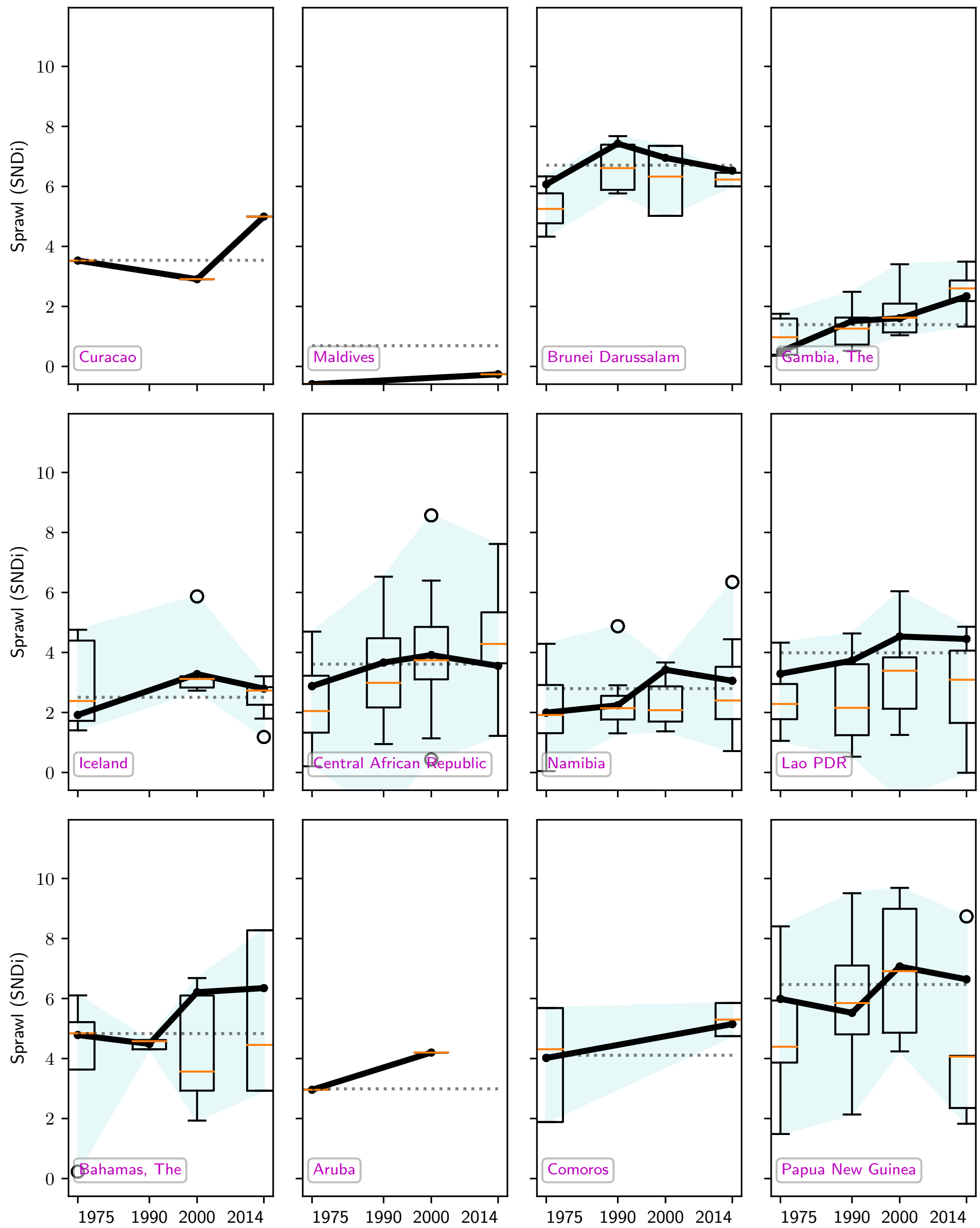

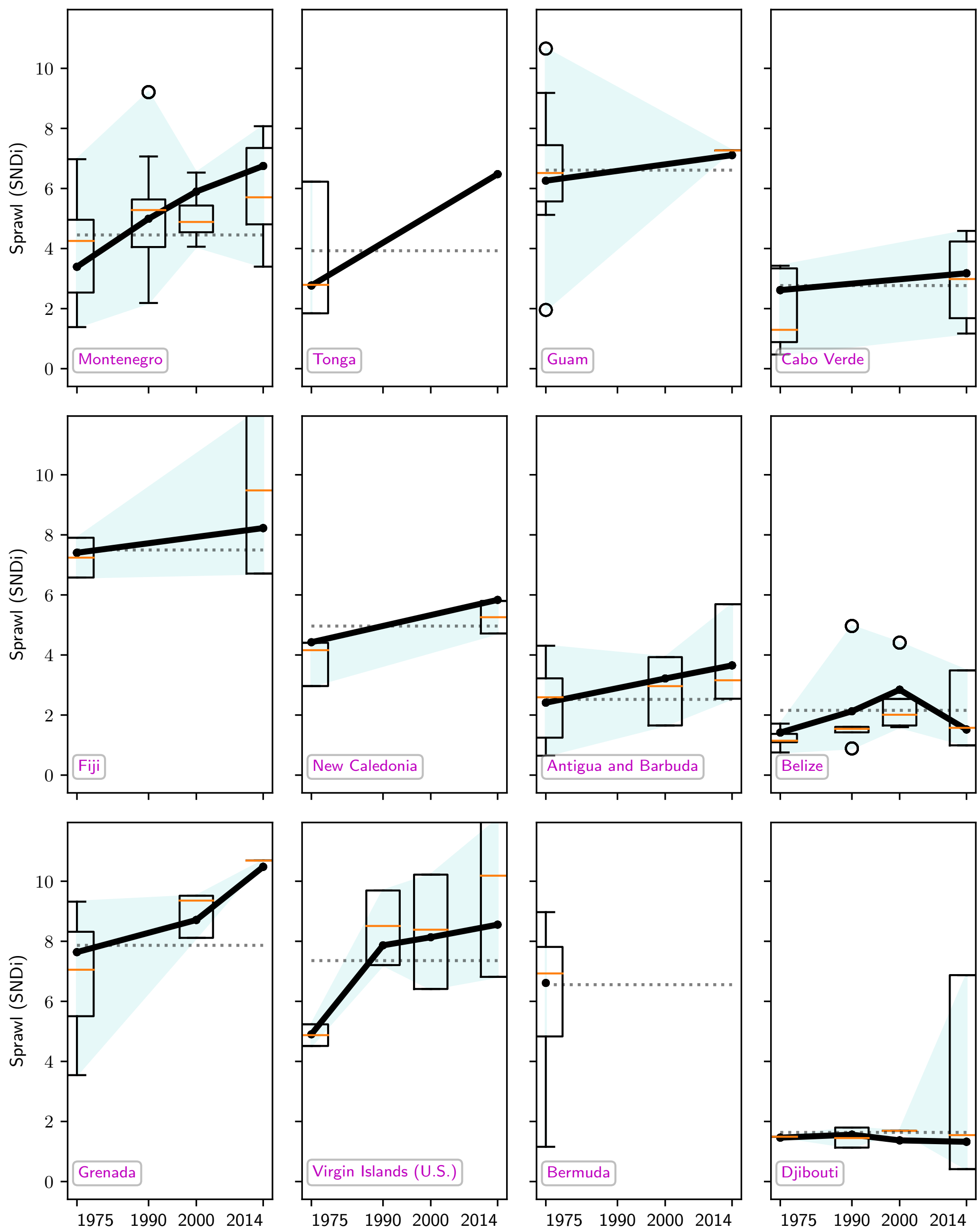

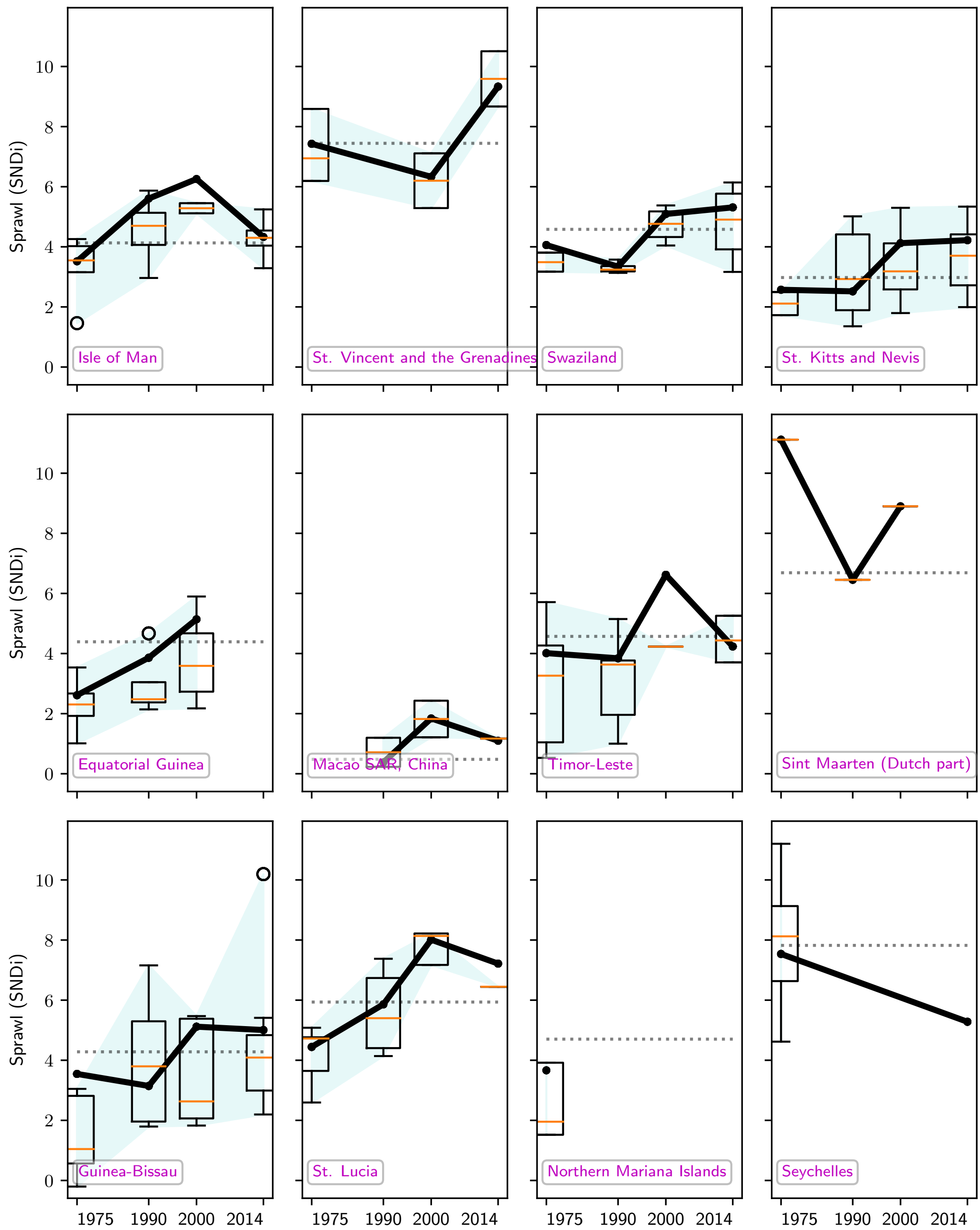

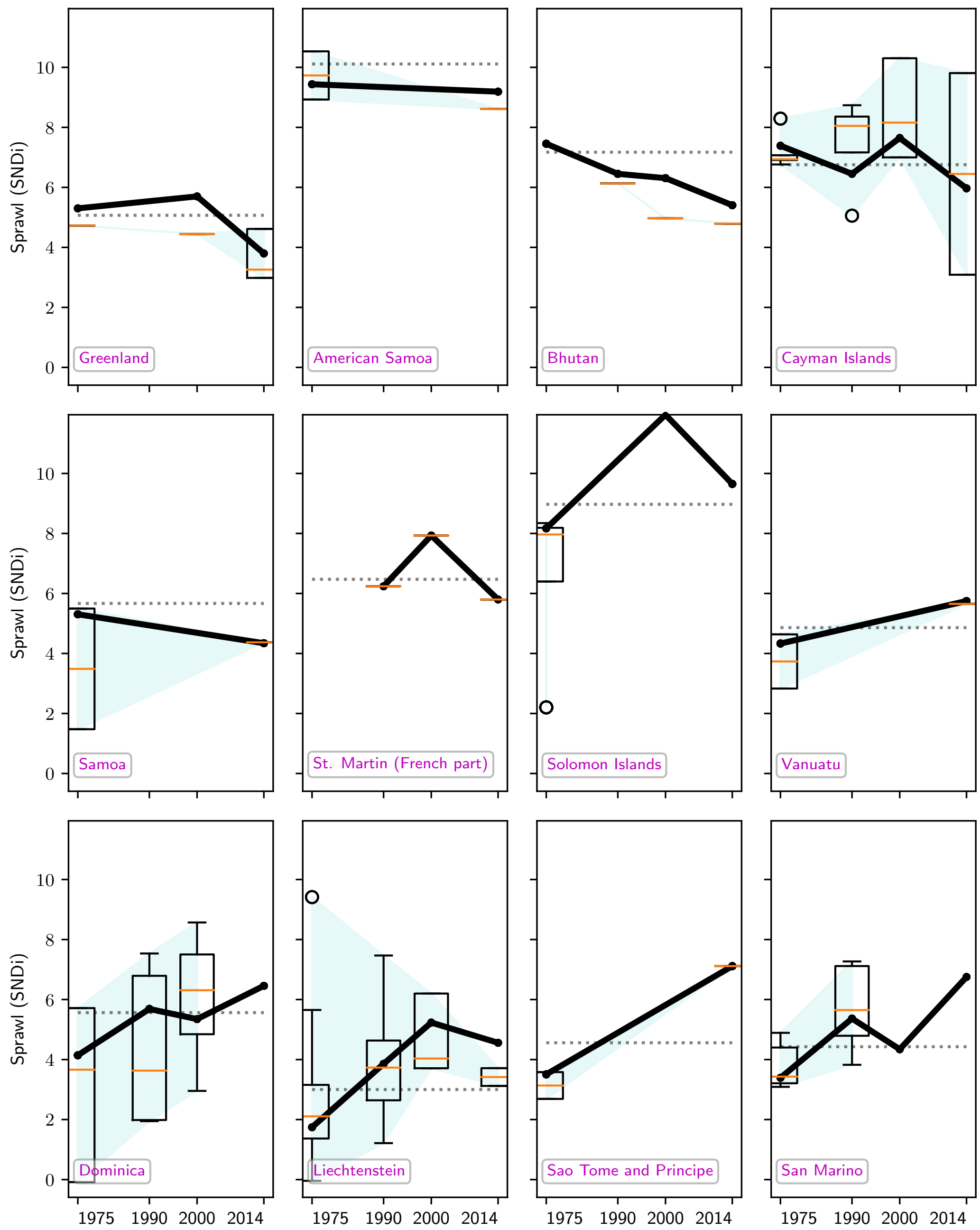

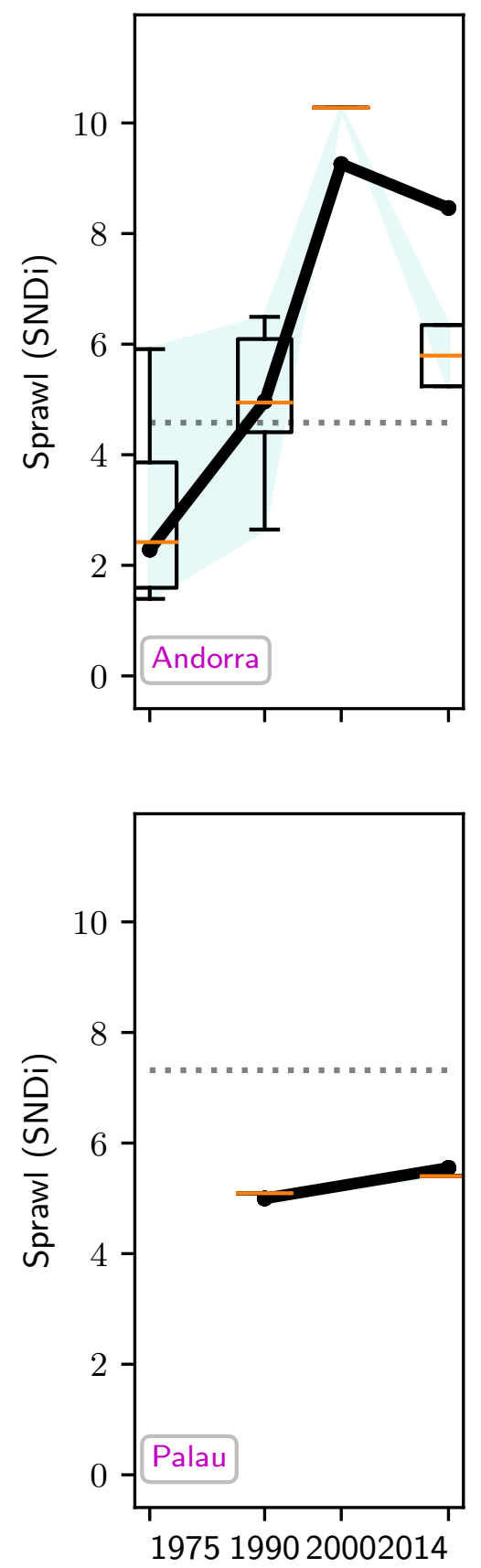
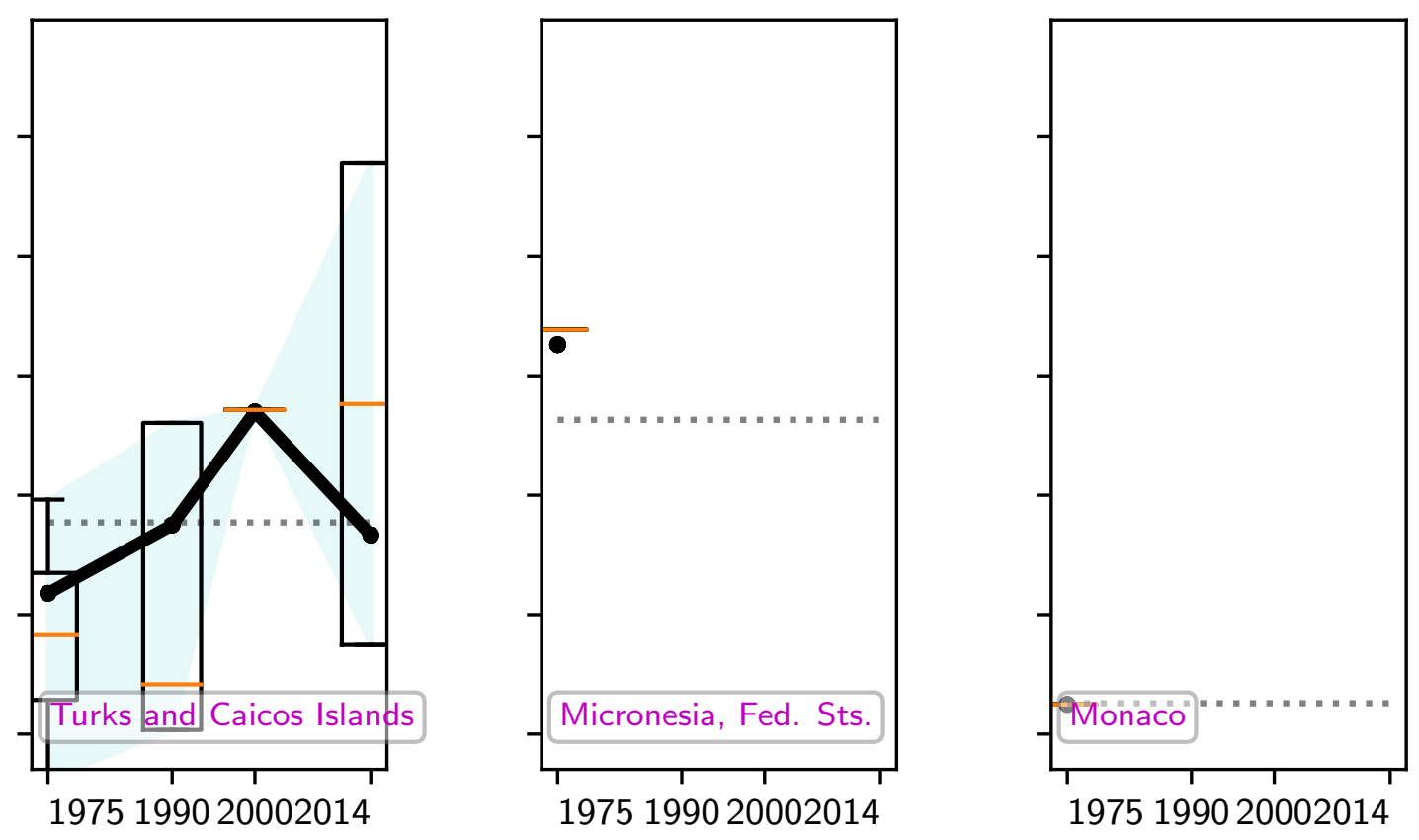


\section{F.11 City trend plots (by region)}

The following plots show city trends in each region. Each line represents one city; in some cases there is more than one city per country. For more detail, see the tabular data. The following pages show results only for SNDi. Other metrics are available online at:

https://alum.mit.edu/www/cpbl/publications/draft2019sprawl. 


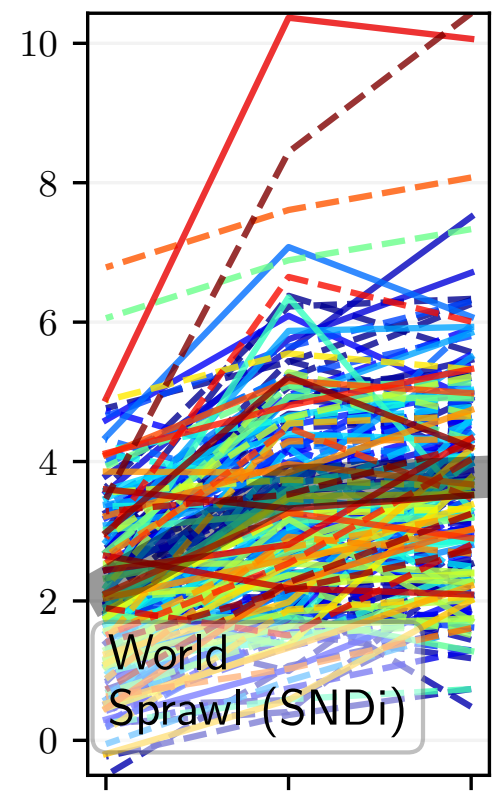

$<1990$ 90-99 2000-13
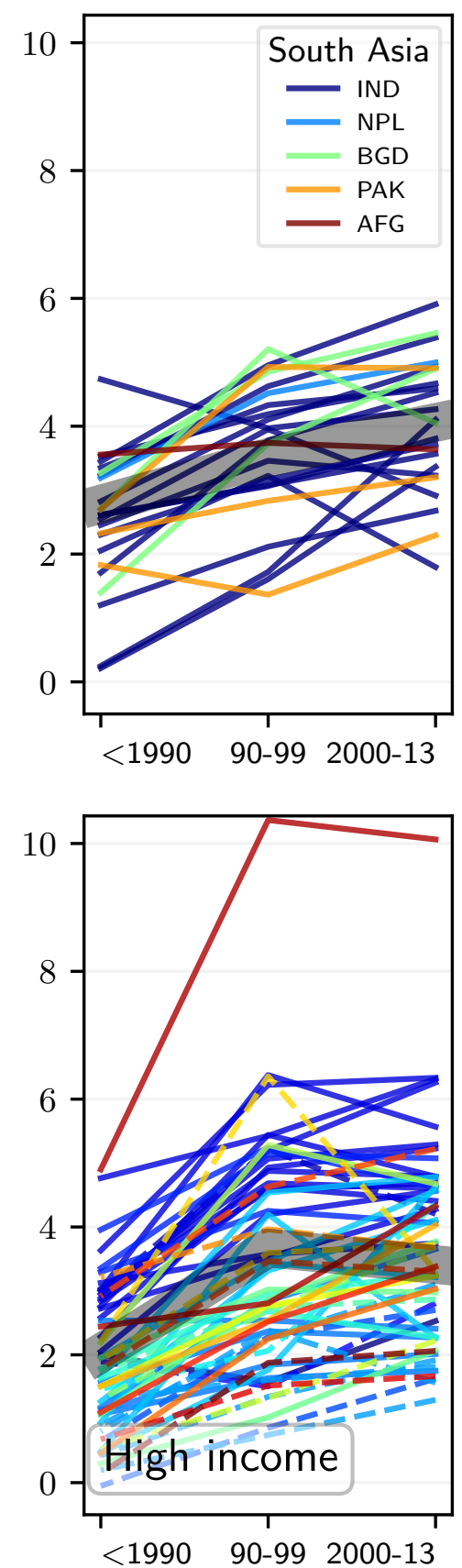
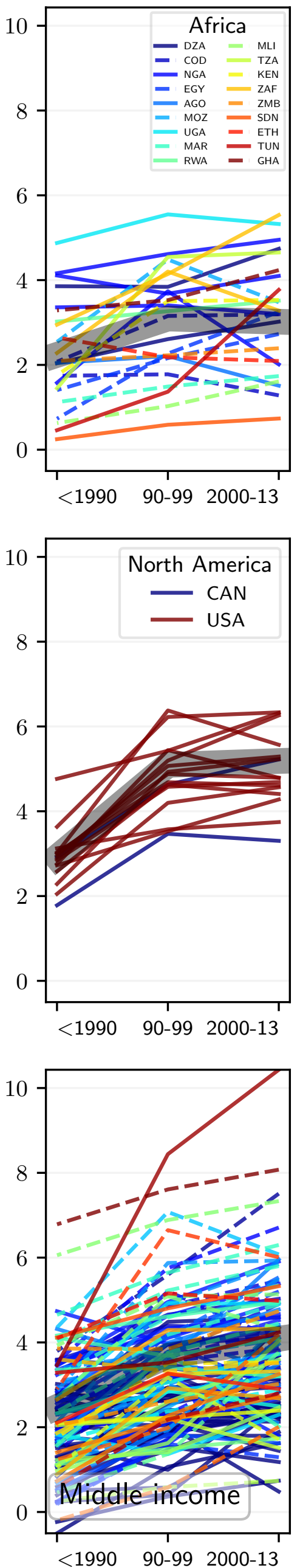
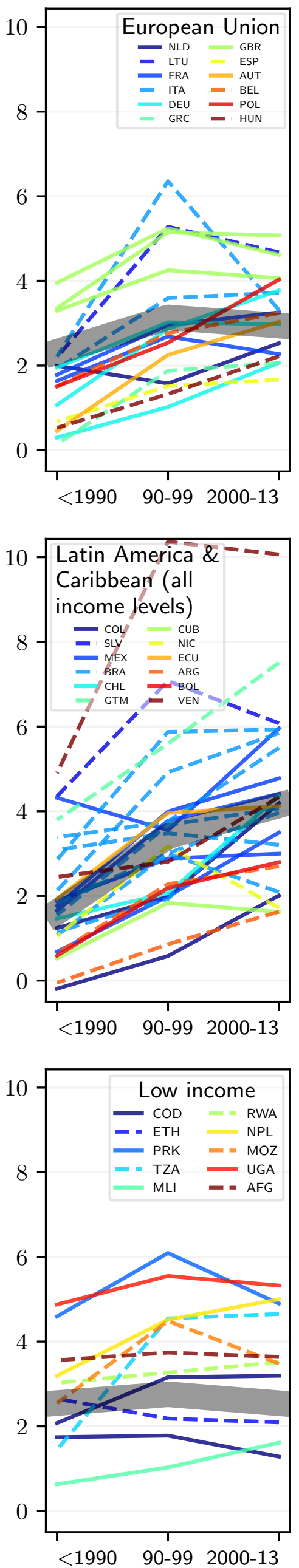

0

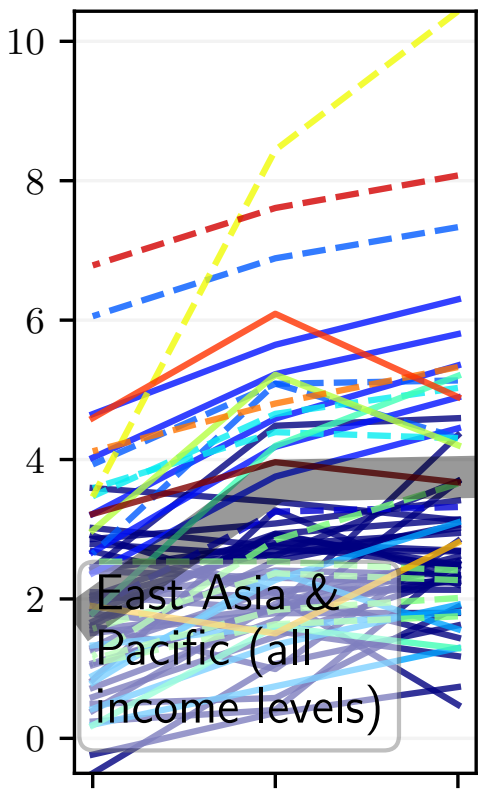

$<1990$ 90-99 2000-13
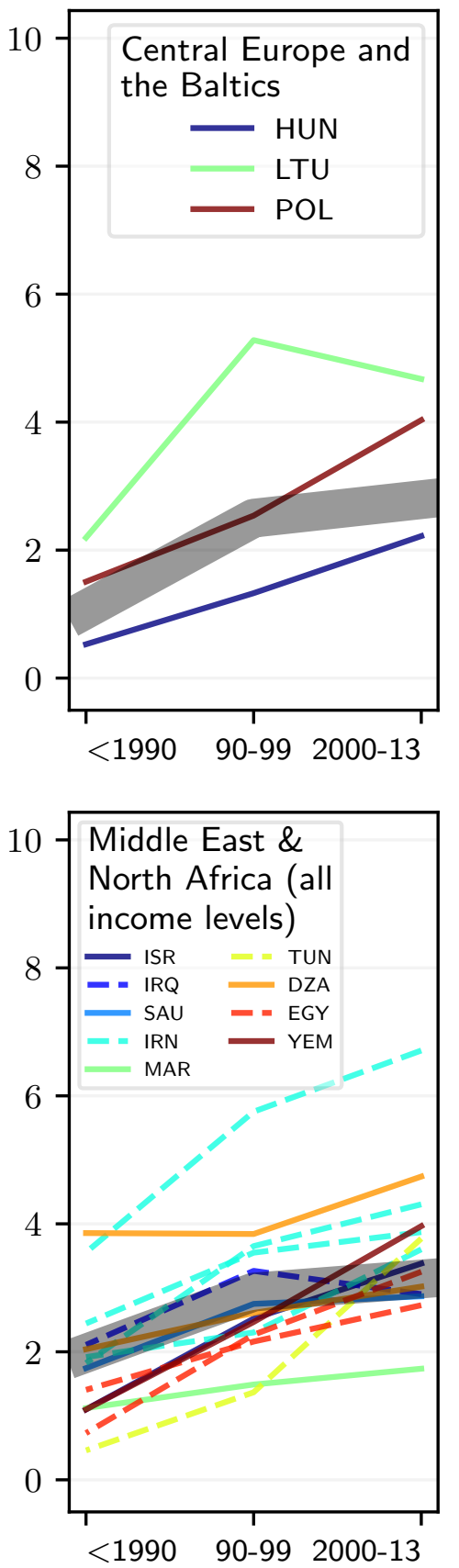

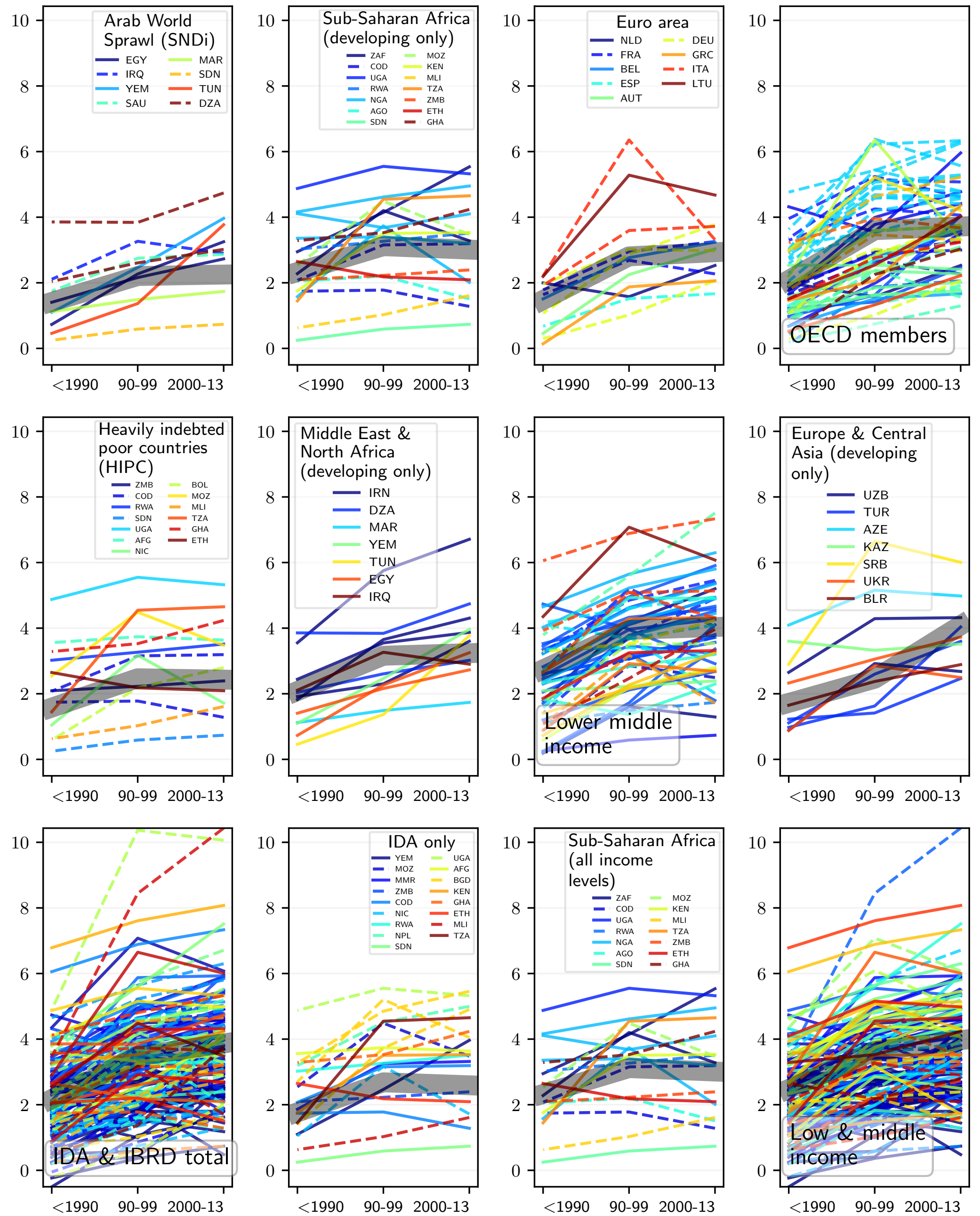

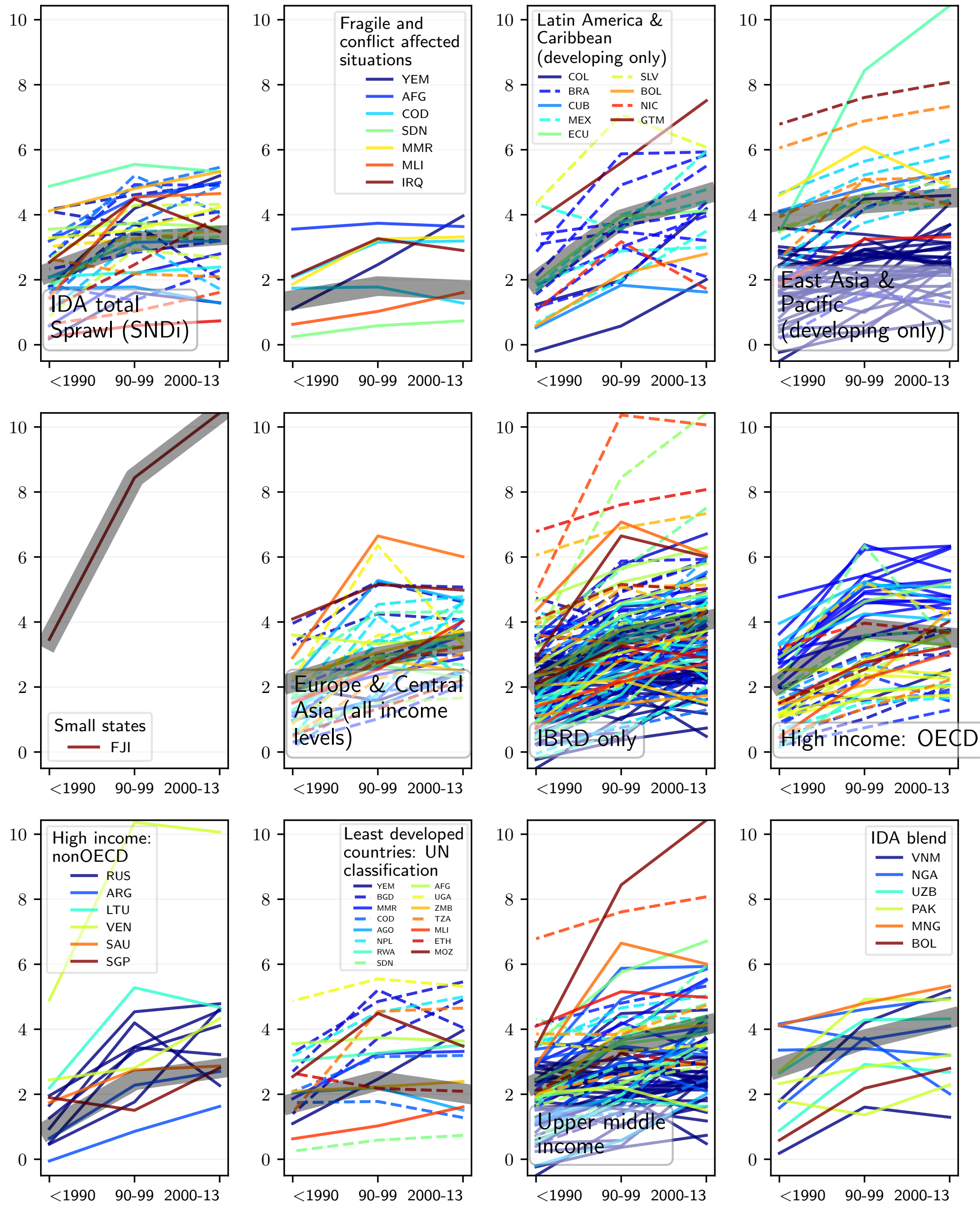


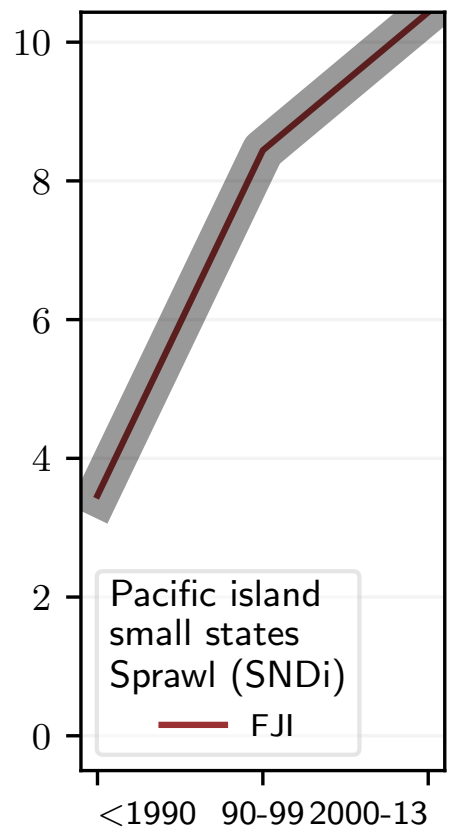




\section{F.12 City trend plots (by country)}

In the plots below, the widest gray line is centered on the trend for the entire country's urban street network, while the less wide gray line is the node-weighted average over only the cities shown (i.e., all those available in the Atlas of Urban Expansion). Quantities are exact; line width does not represent confidence intervals. Countries are ordered by the number of nodes in the 2018 road stock. For more detail, see the tabular data.

The following pages show results only for SNDi. Other metrics are available online at: https://alum.mit.edu/www/cpbl/publications/draft2019sprawl. 

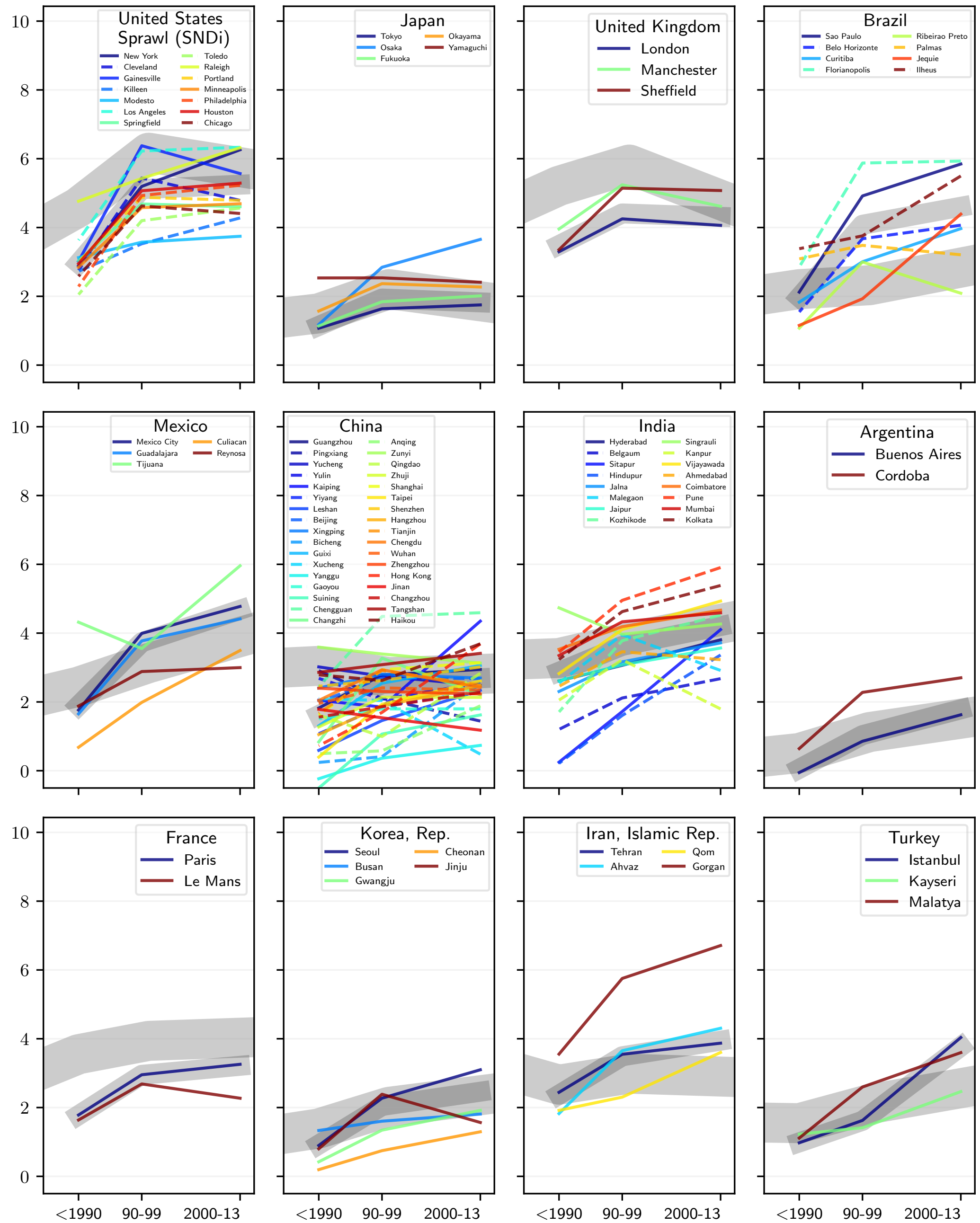

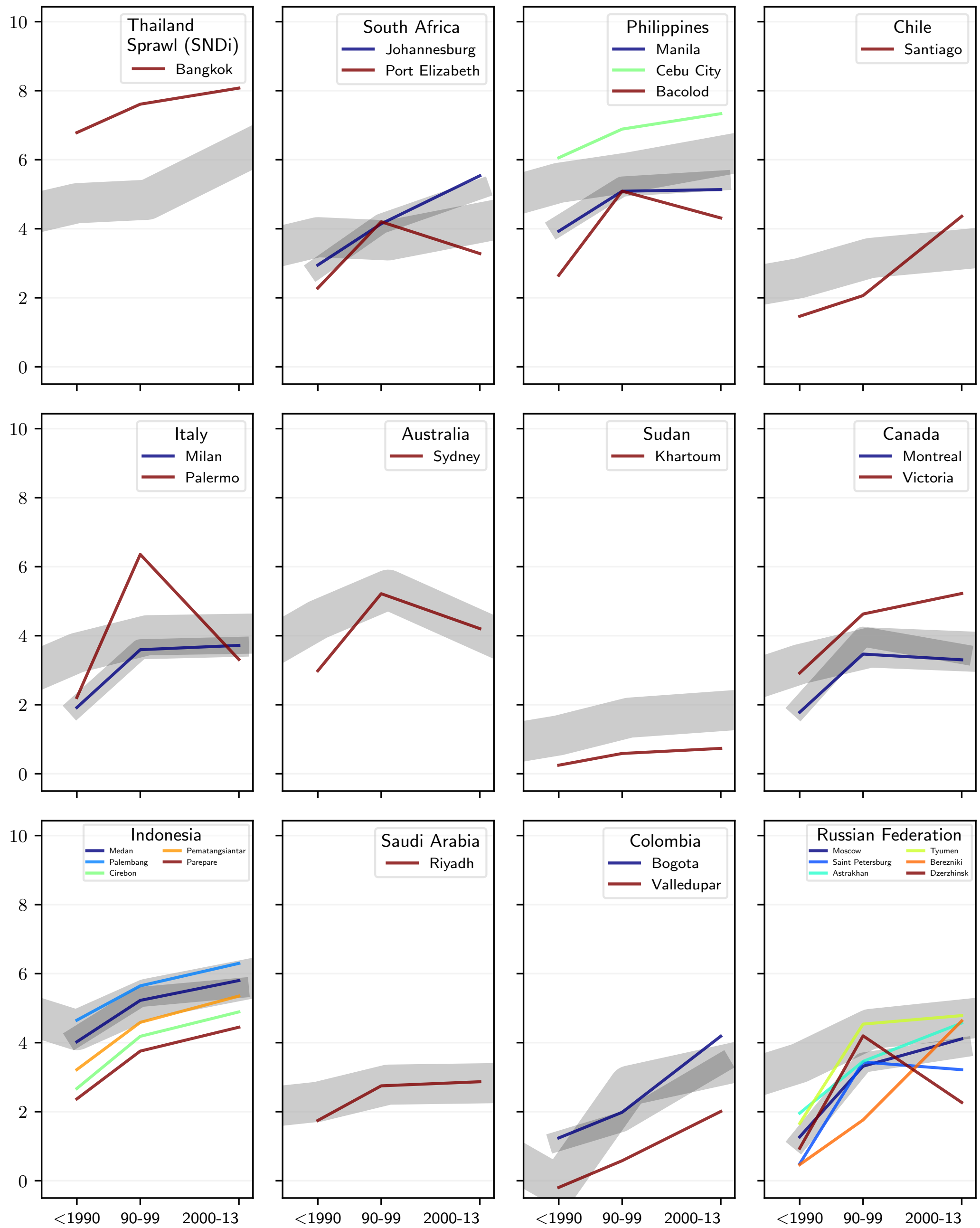

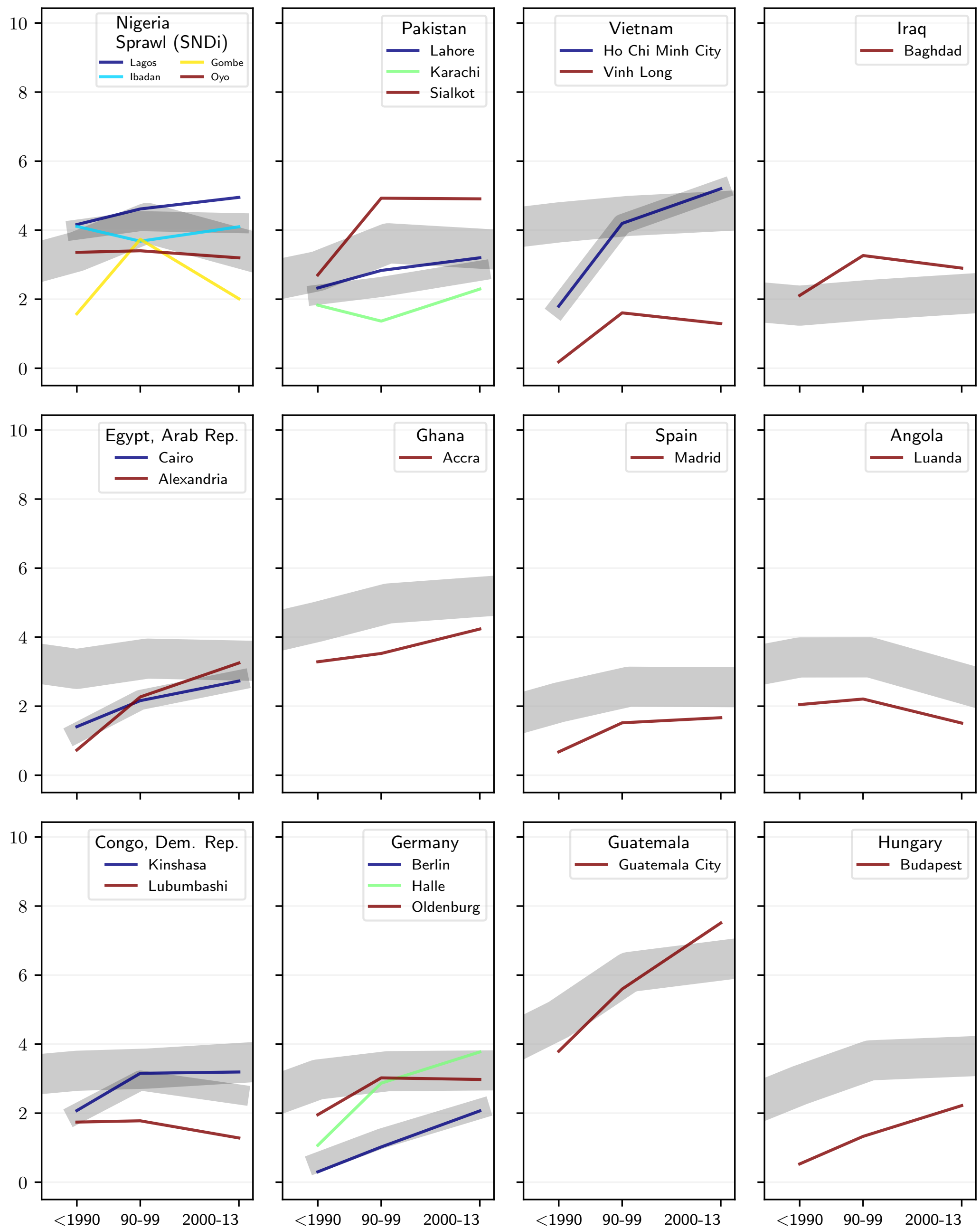

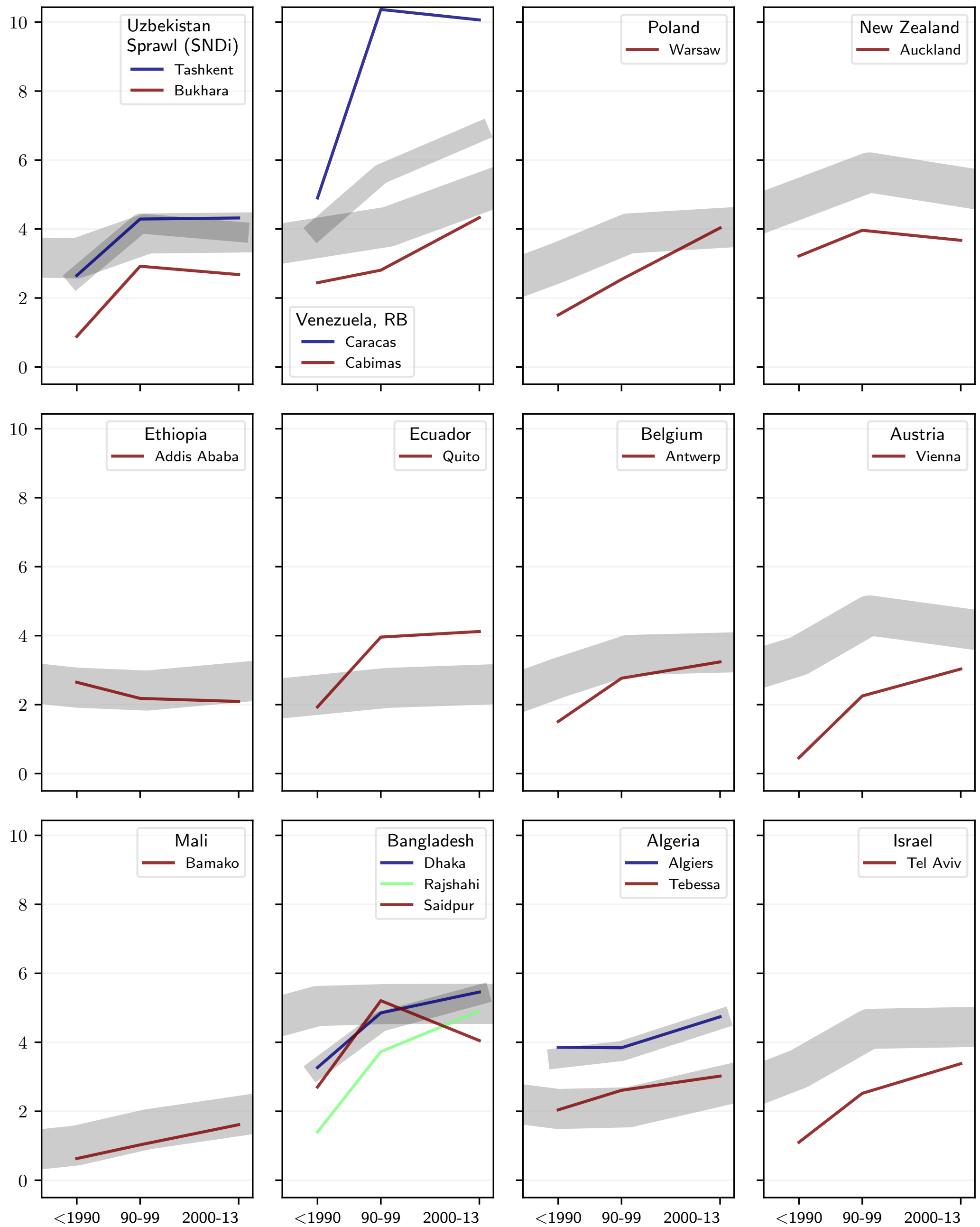

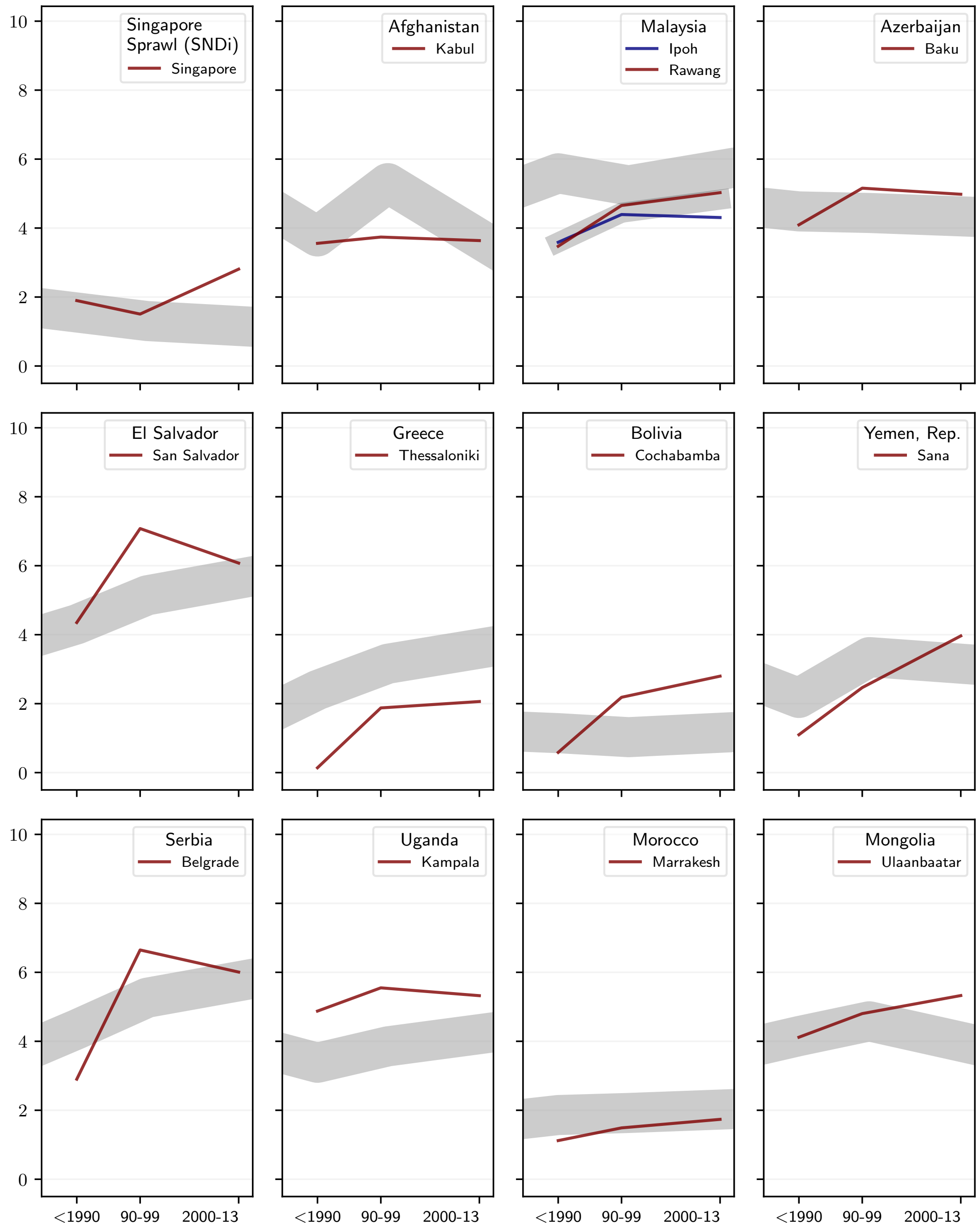

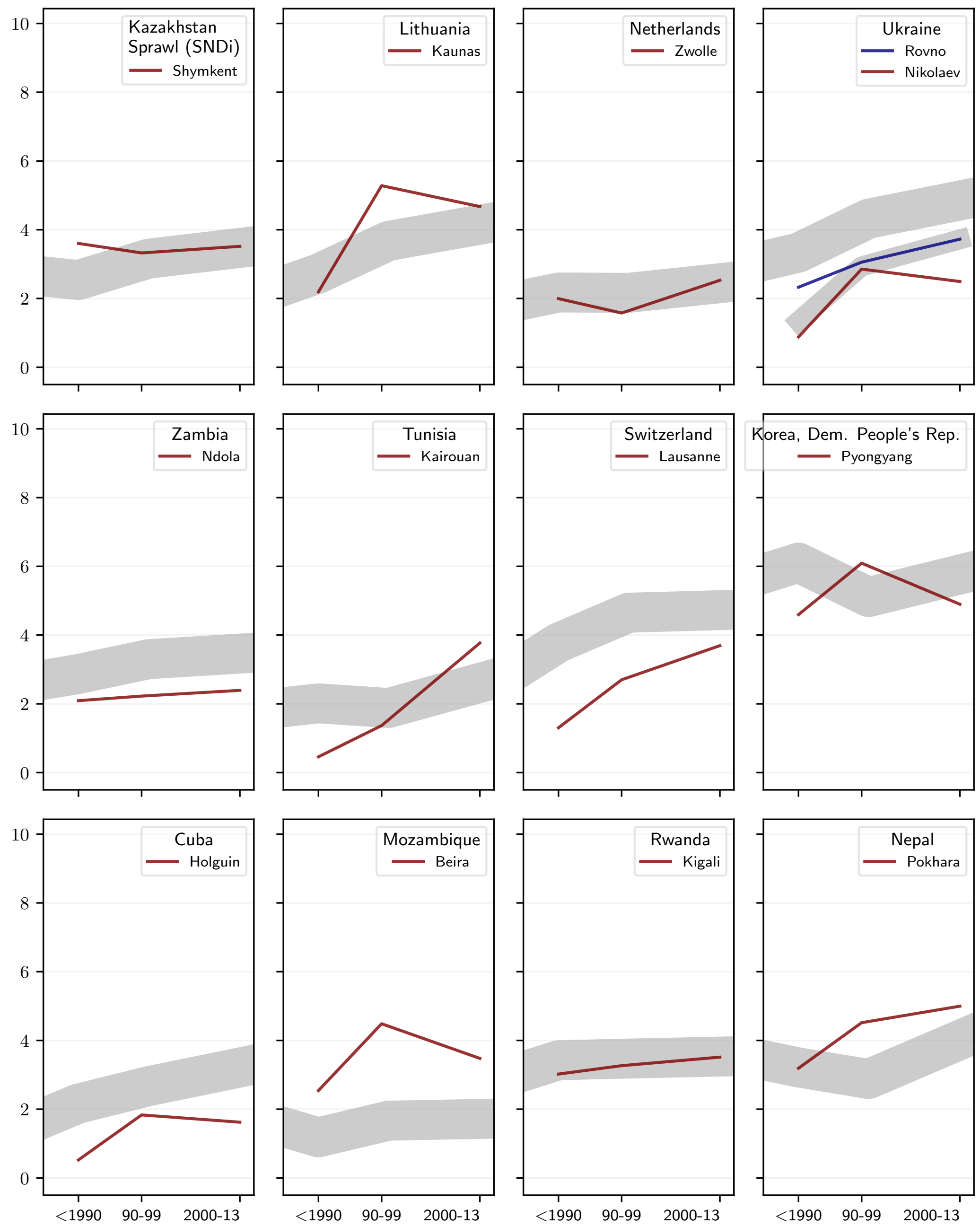

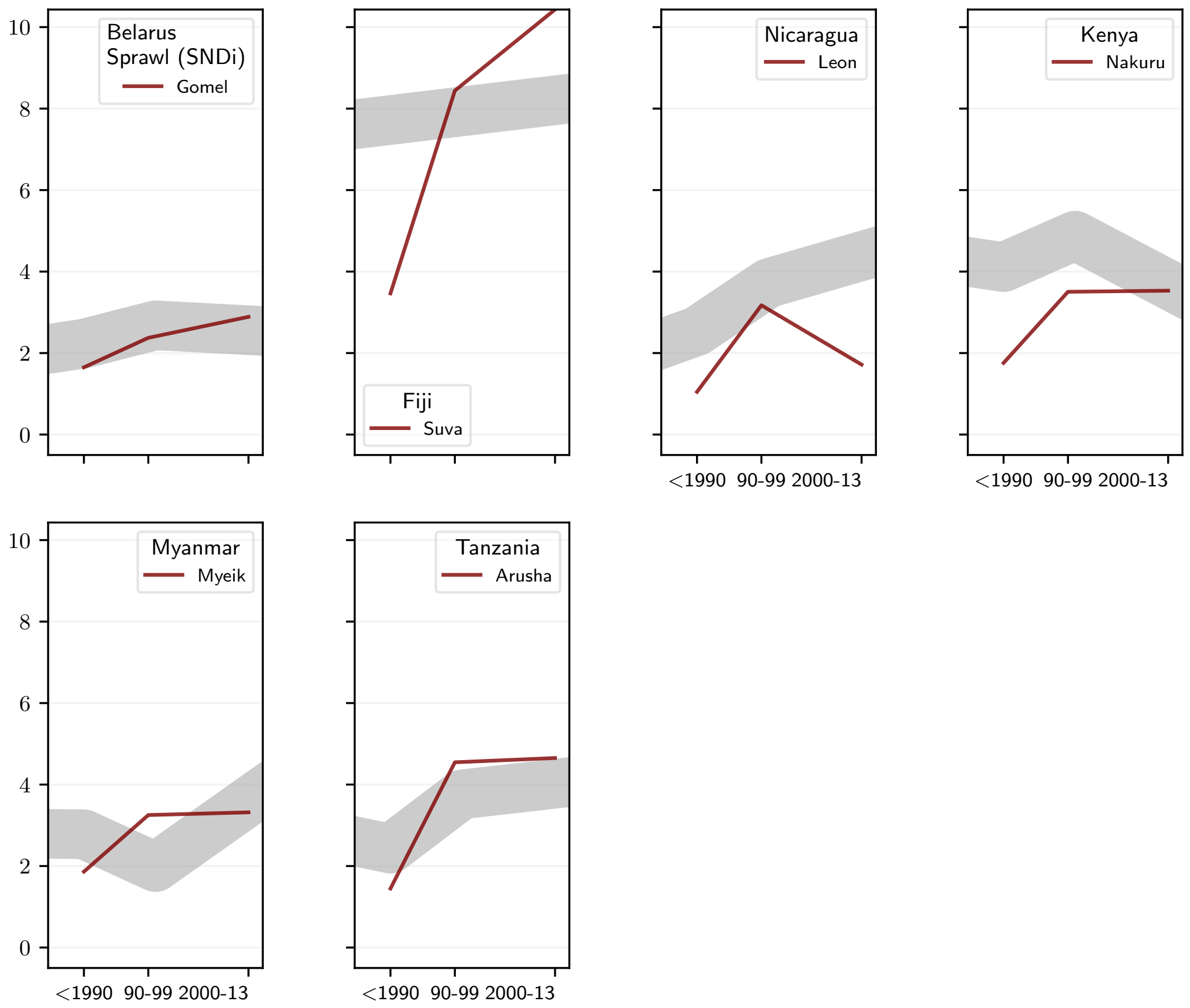